\title{
EFEITO DE BICARBONATO DE SÓDIO, LASALOCIDA E CANA-DE- AÇUCAR SOBRE O DESEMPENHO DE BOVINOS ALIMENTADOS COM BAGAÇO DE CANA TRATADO SOB PRESSÃO DE VAPOR.
}

\section{FLÁVIO AUGUSTO PORTELA SANTOS.}

Engenheiro Agrônomo

Orientador: Prof. Dr. VIDAL PEDROSO DE FARIA

Dissertação apresentada à Escola Superior de Agricultura "Luiz de Queiroz" da Universidade de são Paulo, para obtenção do titulo de Mestre em Agronomia, Area de Concentração: Nutrição Animal e Pastagens. 
EFEITO DE BICARBONATO DE SÓDIO, LASALOCIDA E CANA-DEAÇÚCAR SOBRE O DESEMPENHO DE BOVINOS ALIMENTADOS COM BAGAÇO DE CANA TRATADO SOB PRESSÃO DE VAPOR.

FLAVIO AUGUSTO PORTELA SANTOS

Aprovada em 22:03.1991

Comissão julgadora:

Prof. Dr. Vidal Pedroso de Faria

ESALQ/USP

Prof. Dr. Celso Boin

ESALQ/USP

Prof. Dr. Pedro de Andrade

ECAVJ/UNESP

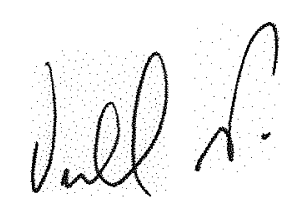

Prof. Dr. Vidal Pedroso de Faria Orientador 
Aos meus pais JOSE E VERA

DEDICO. 


\section{AGRADECIMENTOS}

Ao Prof. Dr. Vidal Pedroso de Faria, pela amizade, orientação dedicada e incentivo permanente.

Ao Prof. Dr. Celso Boin, pelo apoio, sugestões e orientação durante a elaboração e condução do trabalho.

Ao Prof. Alexandre Vaz Pires, pela amizade, incentivo e colaboração.

Aos Profs. Moacyr Corsi e Max I. V. Bose, pela amizade e orientação profissional.

Aos amigos Sila Carneiro da Silva, Luiz Gustavo Nussio e Marco Antonio Pennati, pelo incentivo e colaboração.

Aos estagiarios Heitor Machado de Campos Neto, Luis Gustavo Barioni, José Carlos P. Carramate, Ednir José Gaspar e Laura Maria Vieira da Silva, que tornaram possivel a execução do trabalho.

A Plano Consultoria pela colaboração, amizade e auxílio na obtenção de recursos.

A Destilaria Alcidia S/A, de Teodoro Sampaio, S.P., pelo auxilio na obtenção de recursos.

$\grave{A}$ Roche do Brasil pelo auxilio na obtenção de recursos.

A João Eljias de Lara pelo trabalho de digitação e composição gráfica da Tese.

Ao Laboratório de Bromatologia do Departamento de Zootecnia da ESALQ/USP, pelas análises realizadas. 
SUMÁRIO

Página

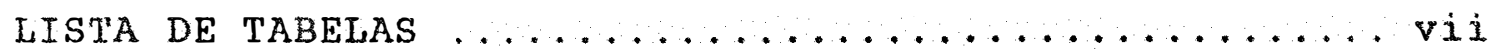

LISTA DE TABELAS DO APENDICE ............... ix

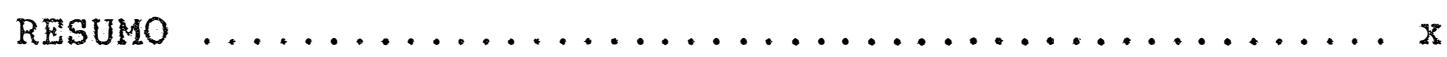

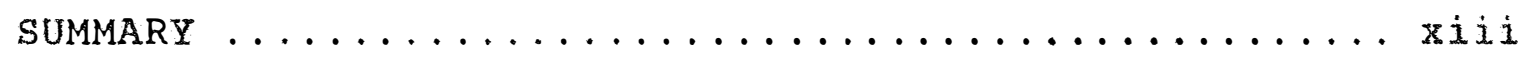

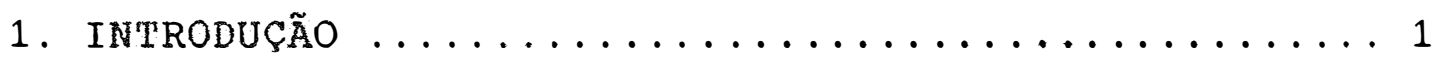

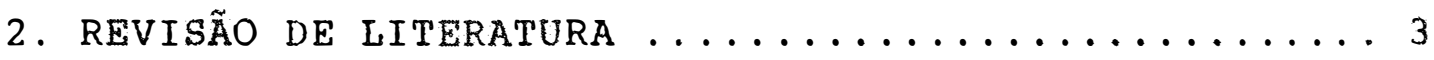

2.1. Potencial do BTPV na alimentação de ruminan-

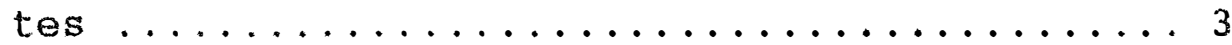

2.2. Uso de agentes tamponantes ............... 10

2.2.1. Considerą̧ões gerais ............. 10

2.2.2. Efeito sobre os parâmetros ruminais ... 12

2.2.3. Efeito de trato digestivo inferior ... 18

2.2.4. Efeito sobre o desempenho animal .....20

2.3. Uso de ionoforos ................... 24

2. 3.1. Conslaerą̧es Gerais ............. 24

2.3.2. Macanismo básico de ação dos ionoforos sobre os microrganismo ruminais ..... 27

2.3.3. Alterações no rúmen e ação sobre utilização de energia e metabolismo protelco 35

2.3.4. Efeito sobre o consumo, a digestibilida de e a taxa de passagem .......... 40

2.3.5. Outrøs efeitos dos ionóforos .......43

2.3.6. Desempenho animal .............46 


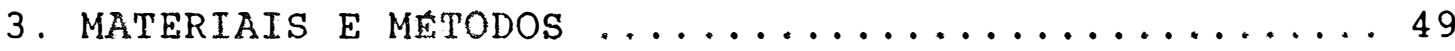

3.1. Hipóteses de trabalho ................ 49

3.2. Local e animais ................... 51

3.3. Tratamentos .................... 52

3.4. Condução do experimento .............. 56

3.4.1. Período pré-experimental ......... 56

3.4.2. Período experimental ........... 56

3.4.3. Coleta de dados ............... 57

3.5. Delineamento experimental ............ 59

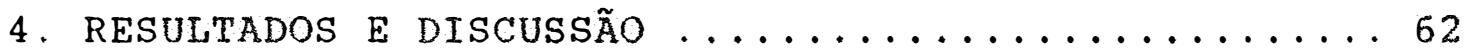

4.1. Consumo de matéria seca $\ldots \ldots \ldots \ldots \ldots \ldots \ldots 6$

4.1.1. Nível e comportamento de consumo .....6 62

4.1.2. Efeito das dietas sobre o consumo .... 69

4.2. Ganho de peso vivo diário ............. 83

4.2.1. Nível e comportamento de ganho de peso 83

4.2.2. Efeito das dietas sobre o ganho de peso 86

4.3. Conversão alimentar ............... 96

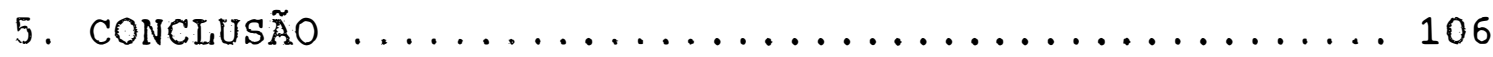

6. REFERÊNCIAS BIBLIOGRÁFICAS $\ldots \ldots \ldots \ldots \ldots \ldots \ldots$

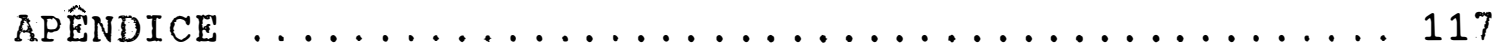




\section{LISTA DE TABELAS}

Página

Tabela 1. Formulação dos concentrados usados no experi

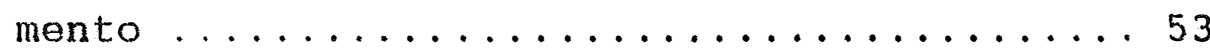

Tabela 2. Proporção dos ingredientes nas dietas experimentais ..................... 54

Tabela 3. Composição estimada dos alimentos utilizados, expressa em base de matéria seca ..... 54

Tabela 4. Composição estimada das dietas experimentais expressa em base de matéria seca......... 55

Tabela 5. Efeito das dietas sobre o consumo diário de MS estimado ...................6 62

Tabela 6 . Consumo diário de nutrientes por um bovino (macho) médio de $393 \mathrm{Kg}$, e por um bovino (fêmea) médio de $335 \mathrm{~kg}$ comparado com suas exigências nutricionais ............666

Tabela 7. Efeito do sexo e do sub-período experimental sobre o consumo de matéria seca .........68

Tabela 8. Efeito das dietas e dos sub-periodos sobre o consumo de $\mathrm{MS} \ldots \ldots \ldots \ldots \ldots \ldots \ldots$

Tabela 9 . Efeito do sexo e das dietas sobre o consumo de matéria seca ..................71

Tabela 10. Efeito do sexo e dos sub-periodos experimen tais sobre o consumo das dietas A e B ... 72 
Tabela 11. Efeito do sexo e dos sub-perfodos experimen tais sobre o consumo das dietas B e D ....76

Tabela 12. Efeito do sexo e dos sub-pexiodos experimen tais sobre o consumo das dieta $A$ e $D \ldots . .78$

Tabela 13. Efeito do sexo e dos sub-perfodos experimen tais sobre o consumo das dietas $C$ e $D \ldots 83$

Tabela 14. Ganho de peso diário de machos e fêmeas ... 84 Tabela 15. Efeito do sexo e das dietas cobre o ganho

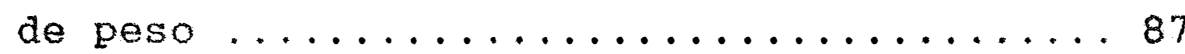

Tabela 16. Efeito do sexo e dos sub-periodos experimen tais sobre o ganho de peso nas dietas $A$ e

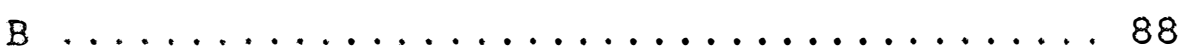

Tabela 17. Efeito das dietas e dos sub-períodos sobre

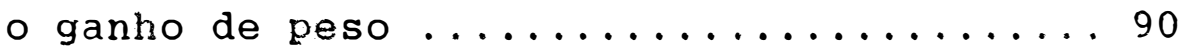

Tabela 18. Efeito do sexo e dos sub-períodos experimen tais sobre o ganho de peso nas dietas $B$ e

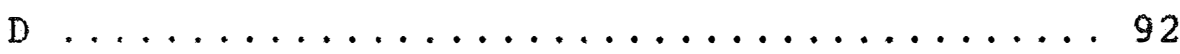

Tabela 19. Efeito do sexo e do sub-periodo experimental sobre o consumo de matéria seca ..... 97

Tabela 20. Efeito das dietas e dos sub-períodos sobre

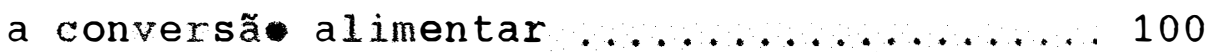

Tabela 21. Efeito do sexo e das dietas sobre a conver são alimentar ......................... 


\section{LISTA DE TABELAS DO APÊNDICE}

Página

Tabela 1. Análise de variância para consumo de matéria seca por $\left(g / \mathrm{Kg} \mathrm{Pv}^{0,75}\right) \ldots \ldots \ldots \ldots \ldots \ldots \ldots$

Tabela 2. Análise de variância para ganho de peso em

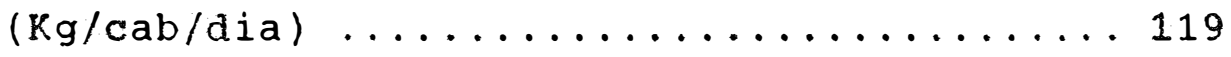

Tabela 3. Análise de variância para conversão alimen-

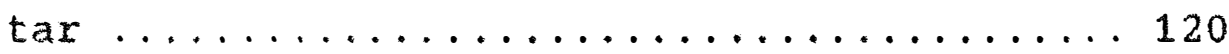

Tabela 4. Planilha de dalos usados para a análise de consumo (CPM) e conversão alimentar (CA) ... 121

Tabala 5. Planilha de dados usados para a análise de ganho de peso corrigido para o peso vivo

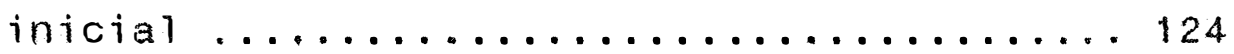


EFEITO DE BICARBONATO DE SODDIO, LASALOCIDA E CANA-DEAÇUCAR SOBRE O DESEMPENHO DE BOVINOS ALIMENTADOS COM BAGAÇO DE CANA TRATADO SOB PRESSÃO DE VAPOR.

Autor: FLÁVIO AUGUSTO PORTELA SANTOS orientador: Prof. Dr. VIDAL PEDROSO DE FARIA

RESUMO

o experimento foi conduzido para avaliar o efeito do $\mathrm{NaHCO}_{3}$ ( $1 \%$ na matéria seca), da lasalocida sódica (20 a 30 ppm da matéria seca), e da ausência de cana-deasúcar como fonte de fibra integra para bovinos confinados recebendo dietas à base de bagaço de cana tratado sob pressão de vapor (BTPV). Foram utilizados 40 animais da raça nelore com peso vivo médio inicial de $329 \mathrm{~kg}$ e idade inicial de 18,9 meses, sendo 24 machos e 16 fêmeas. O delineamento estatístico usado foi o fatorial em blocos casualizados, constando de 3 blocos, 4 dietas, 2 sexos e 5 sub-periodos experimentais. As 4 dietas utilizadas foram: A (50\% BTPV, 10\% de cana picada e $40 \%$ de concentrado, base seca); B (50\% BTPV, 10\% de cana picada, 40\% de concentrado e lasalocida sódica); C (60\% BTPV, $40 \%$ de concentrado, lasalocida sódica e $\mathrm{NaHCO}_{3}$ ) e D (50\% BTPV, $10 \%$ de cana picada, $40 \%$ de concentrado, Tasalocida sódica e $\mathrm{NaHCO}_{3}$ ). Todas as dietas eram isoproteicas $(12,76$ a $13,77 \%$ PB $)$ e isoenergéticas $(58,8$ a $60,4 \%$ de NDT), apresentando 0,27 a $0,36 \%$ de $\mathrm{Ca}$ e 0,13 a $0,14 \%$ de P. Mistura 
mineral à vontade foi oferecida continuamente. O período préexperimental foi de 25 dias e o experimental teve duração de 66 dias. O consumo de matéria seca $\left(\mathrm{g} / \mathrm{Kg} \mathrm{PV} \mathrm{P}^{0,75}\right)$, ganho de peso (Kg) e conversão alimentar para as dietas foram: A: 135,53 , $1,15,11,47 ; B: 129,07,1,17,10,92 ; C: 130,02,1,18,10,14 ;$ D: $139,71,1,30,10,50$. A adição de lasalocida sódica reduziu o consumo de matéria seca sem afetar o ganho de peso, havendo tendência de melhorar a conversão alimentar. A adição de bicarbonato de sódio em presença de lasalocida aumentou o consumo de matéria seca, havendo tendência de melhorar o ganho de peso e a conversão alimentar nos primeiros 56 dias do período experimental. Após esta fase, o $\mathrm{NaHCO}_{3}$ prejudicou o desempenho animal. O efeito depressivo da lasalocida sódica sobre o coneumo de matéria seca e o desempenho animal na fase inicial de fornecimento foi reduzido ou anulado pelo $\mathrm{NaHCO}_{3}$. A associaçáo $\mathrm{NaHCO}_{3}$ e lasalocida sódica aumentou o consumo de matéria seca, havendo tendência de melhorar o ganho de peso e a conversã alimentar nos primeiros 56 dias de fornecimento. Após esta fase a associação $\mathrm{NaHCO}_{3}$ e lasalocida prejudicou o desempenho animal. A ausência de cana picada reduziu o consumo de matéria seca, havendo tendência de piorar o ganho de peso, porém a conversão alimentar não foi afetada. De modo geral a associação do bicarbonato de sódio com a lasalocida sódica parece ser benéfica em dietas à base de BTPV enquanto a adicão de cana picada só se justifica quando se pretende estimular o consumo da dieta. Os machos ganharam significativamente mais peso, e foram mais 
eftolentes qua as emeas, que consumiram mais alimento por unldade de peso metabólico. o ganho de peso médio foi elevado sendo obtido para machos $1,33 \mathrm{~kg}$ e para as fêmeas $1,06 \mathrm{~kg}$, sendo proposto a pessivel existência de efeito compensatório no ganho. Houve efeito significativo de periodo e em todas as variveis estudadas, ocorrendo com o tempo no consumo e ganho de peso tendência de redução, e na conversão alimentar tendência de piora. Não foram detectadas interações significativas entre as variáveis estudadas a não ser entre periodo e tratamento para conversăo alimentar. 
EFFECT OF SODIUM BICARBONATE, SODIUM LASALOCID AND SUGAR CANE ON THE PERFORMANCE OF BOVINES FED DIETS BASED ON STEAM PRESSURE TREATED SUGARCANE BAGASSE.

Author: FLÁVIO AUGUSTO PORTELA SANTOS Adviser: VIDAL PEDROSO DE FARIA, Dr.

SUMMARY

One trial was conducted to determine the effect of sodium bicarbonate ( $1 \%$ of DM), sodium lasalocid ( 20 to $30 \mathrm{ppm}$ of $\mathrm{DM})$, and chopped sugar cane (10\% of DM) on the perfermance of growing and finishing beef yearling bulls and helfers fed steam pressure treated sugarcane bagasse (SPTB) diets. Forty animals (26 nelores yearling bulls and 14 heifers) aging 18,9 months and showing initial weigh of $329 \mathrm{~kg}$ were used in a randomized block factorial design with 3 blocks, 4 diets, 2 sexs and 5 experimental periods (10 to 14 days). Diets used on a dry bases were: A (50\% SPTB, 10\% sugar cane and $40 \%$ concentrate); B (50\% SPTB, 10\% sugar cane, $40 \%$ concentrate and lasalocid); C (60\% SPTB, $40 \%$ concentrate, lasalocid and sodium bicarbonate); D (50\% SPTB; 10\% sugar cane, $40 \%$ concentrate, lasalocid and sodium bicarbonate). A 11 
diets were isonitrogenous $(12-13 \% \mathrm{CP})$ and isocaloric $(59-60 \%$ TDN), presenting 0,27 a $0,36 \% \mathrm{Ca}$ and $0,14 \% \mathrm{P}$. Free choice mineral mixture was offered continuousiy. Preliminary period was 25 days and the experimental 66 days. Average dry matter intake $\left(\mathrm{g} / \mathrm{Kg} P V^{0.75}\right)$, daily gain $(\mathrm{Kg})$ and feed conversion ( $\mathrm{kg}$ $\mathrm{DM} / \mathrm{Kg}$ gain) were: $\mathrm{A}: 135,53,1,15,11,47 ; \mathrm{B}: 129,07,1,17$, 10,$92 ; C: 130,02,4,18,10,14 ; 0: 139,71,1,30,10,50$. The addition of sodium lasalocid decreased dry matter intake but did not affect daily gain; there was tendency to improve feed conversion. The addition of sodium bicarbonate and sodium lasalocid increased dry matter intake, and there was a tendency. to improve daily gain and feed conversion only in the first 56 days of the experimental period. After this point sodium bicarbonate reduced animal performance. Sodium bicarbonate reduced or annulled the negative effect of sodium lasalocid on dry matter intake, daity gain and feed conversion in the first period. The association of sodium bicarbonate and sodium lasalocid increased dry matter intake, and there was a tendency to improve daily gain and feed conversion in the first 56 days of the experimental period. After this phase, its effect was negative. No addition of sugar cane reduced dry matter intake, and there was tendency to reduce daily gain, but feed conversion was not affected. Yearling bulls showeded faster gains and were more efficient then heifers which had a higher dry matter intake $(\mathrm{g} / \mathrm{kg}$ $\left.P V^{0,75}\right)$. Both yearling bul1s $(1,33 \mathrm{~kg})$ and heifers $(1,06 \mathrm{~kg})$ average daily gains were high, and it was suggested that 
there was compensatory growth occourre. There was a significant effect of period and it was observed from the beggining to the end a tendency for reduced dry matter intake and daily gain and higher values for feed conversion. There was a significant interaction between period and treatment for feed conversion. 
1. INTRODUCAOO

A utilizaçă de residuos agro-industriais na alimentação de ruminantes tem despertado o interesse de diversos pesquisadores no mundo todo durante os últimos anos. Um methor aproveitamento das áreas e produtos agricolas, assim como a redução da competição entre ruminantes e o homem por áreas e produtos alimenticios nobres, são aspectos discutidos por estudiosos no assunto.

O principal resíduo lignocelulósico produzido no Brasil é o bagaço de cana-de-açúcar. Proveniente da moagem da cana, o bayaco se apresenta como um alimento de baixo valor nutritivo, limitando o desempenho animal quando ultrapassa 30 a $40 \%$ da matéria seca da dieta. Com a finalidade de melhorar o valor nutritivo deste residuo, o tratamento sob pressão de vapor vem sendo bastante utilizado pela indústria sucro-alcooleira.

o bagaço de cana-de-açúcar tratado sob pressão de vapor (BTPV) apresenta caracteristicas bem distintas do material original, tais como: a) maior digestibilidade; b) maior teor de carboidratos solúveis; c) maior acidez; d) maior friabilidade; e) menor tamanho de particula. Por ser um 
alimento bastante ácido, com pH entre 2,8 a 3,6 , bastante friável e com particulas de tamanho reduzido, é de se supor que o pH ruminal caracteristico em dietas à base de BTPV seja desfavorável à degradação da sua fração fibrosa. Distúrbios metabólicos como acidose e timpanismo também poderiam ocorrer, prejudicando o desempenho animal.

Vários trabalhos de pesquisa têm mostrado o efeit benefico do uso de agentes tamponantes, evitando a queda brusca do $\mathrm{pH}$ ruminal em animais recebendo dietas ricas em grãos ou à base de a 1 imentos ácidos como a s i lagem. Ionóforos também têm se mostrado eficientes em evitar queda brusca de pH ruminal, em reduzir a incidência de timpanismo e em aumentar a eficiência de utilização do alimento, resultando em melhor desempenho animal.

o presente trabalho teve por finalidade avaliar o efeito da adição de bicarbonato de sódio, lasalocida sódica e a ausència de cana-de-açúcar como fonte de fibra integra no desempenho de bovinos confinados, recebendo dietas à base de BTPV. 


\section{REVISÃo dE LITERATURA}

\subsection{Potencial do BTPV na Alimentação de Ruminantes}

Com a implantação do Pró-álcool no Brasil, ocorreu inicialmente uma grande expansão das destilarias anexas às usinas e, em uma segunda fase, a implantação de destilarias autonomas. Estas, com uma tecnologia mais avançada, principalmente quanto à geraçăo de vapor, conseguem obter uma maior sobra de bagaço por tonelada de cana moída, o que inicialmente tornou-se um fator de custo. Estudos foram então realizados com a finalidade de dar um destino econômico ao bagaço (RUAS, 1989). Geração de energia, produção de pape1, chapas e aglomerados e alimentação anima1, são algumas das alternativas para a utilização do bagaço de cana-deaçúcar, que vem deixando de ser considerado um residuo problema para se transformar em um sub-produto com importante valor comercial (BURGI, 1987; RUAS, 1989).

Nas regiões industrializadas existe mercado

para o bagaço de cana-de-açúcar, que é utilizado principalmente como fonte de energia por outras indústrias, sendo que o valor alcançado pela tonelada de bagaço pode chegar a se igualar ou até mesmo superar o preço da tonelada 
de cana (BURGI, 1987). Durante a safra de 1987/1988, o preço médio obtido pela tonelada de bagaço no estado de são Paulo foi de 75 a 80\% do preço da tonelada de cana colocada na usina (RUAS, 1989). As usinas e destilarias localizadas longe dos centros industriais dificilmente conseguem comercializar as sobras de bagaço, e quando o fazem, o preço obtido é bem inferior ao mencionado anteriormente (RUAS, 1989).

o interesse na utilização das sobras de bagaço na alimentą̧ão animal vem crescendo nos últimos anos, pois multas destilarias de álcool foram instaladas em regios tipicamente de pecuária de corte, sendo os sócios e fornecedores dessas destilarias, em sua maioria, pessoas ligadas à atividade pecuária (BURGI, 1987). Além disso, com a atual crise do pró-Alcool, existe uma tendencia de diversificação das atividades da indústria sucroalcooleira e - aproveitamento do bagaço aparece como uma das opçōes para essa diversificação.

Na atualidade, o bagaço de cana tratado sob pressão de vapor (BTPV) vem sendo utilizado principalmente na engorda de bovinos em confinamentos nas próprias usinas e destilarias. Como essas indústrias têm capacidade para confinar um número bastante grande de animais, a tendência que está se verificando é que as usinas e destiliarias têm confinado um determinado número de animais de sua propriedade e oferecido instalação, alimentação e mão-de-obra para a engorda de bois de pecuaristas em um esquema de "prestação de 
serviços", que reduz os riscos e o valor do investimento para a aquisição de animais (PLANO CONSULTORIA, 1990).

Uma indústria com capacidade para moer 10.000 toneladas de cana por dia, durante 6 a 8 meses de safra, teria uma sobra de 500 toneladas por dia de bagaço ou 120.000 toneladas por safra. Esta quantia permitiria alimentar aproximadamente 60.000 bois durante 120 dias em regime de confinamento.

Outra opção que vem sendo bastante utilizada é a venda do BTPV ou da própria ração completa (BTPV + concentrado) para pecuaristas com propriedades próximas às indústrias, seja para a engorda em confinamento ou para a suplementação à pasto de vacas de cria e animais em recria. BERCHIELLI et alii (1989), utilizando dietas com $85 \%$ de BTPV e $15 \%$ de concentrado na matéria seca, obtiveram ganhos de peso de $0,52 \mathrm{~kg} / \mathrm{dia}$ com bovinos de 10 meses de idade pesando em média $200 \mathrm{~kg}$. Segundo BURGI (1986) o fornecimento diário de $12 \mathrm{~kg}$ de BTPV, $80 \mathrm{~g}$ de uréia, e suplemento mineral, pode atender às exigências de manutenção de vacas de cria não lactantes.

Essas práticas podem se tornar interessantes para pecuaristas localizados próximos às usinas e destilarias, desde que o preço do BTPV seja compensador, e possibilitariam explorar intensivamente as pastagens durante - periodo das chuvas, sem a necessidade de se reservar áreas para a produção de alimentos ou pastejo diferido. 
A sobra de bagaço de cana no Brasil situa-se na faixa de 5 a 12 milhões de toneladas por ano (BURGI, 1987). Na hipótese de se contar com 5,5 milhões de toneladas, seria possivel alimentar 2.700 .000 cabeças durante 120 dias de confinamento. O número oficial de bovinos abatidos diariamente no Brasil situou-se entre 30 a $40 \mathrm{mil}$ durante o ano de 1989 (PREÇOS AGRÍCOLAS, 1989). Com um abate médio de 30.000 cabeças por dia, a engorda de 2.700 .000 cabeças poderia suprir o mercalo nacional durante os 3 meses criticos do periodo da entressafra.

O número total de animais confinados no Brasil nos ultimos 4 anos tem oscilado entre 300 a 60 mil cabecas (URGI, 1987), sendo a participação dos animais alimentados com BTPV em torno de 10 a $15 \%$ do total.

Resultados de desempenho animal com rações à base de BTPV foram compilados e são apresentados nos dados que se seguem, referentes a confinamentos experimentais.

\begin{tabular}{|c|c|c|c|c|c|c|c|c|c|}
\hline $\begin{array}{c}\text { Referen- } \\
\text { cla } \\
\text { no }\end{array}$ & $\begin{array}{l}\mathrm{PHi} \\
\mathrm{Kg}\end{array}$ & $\begin{array}{l}\text { Dias } \\
\text { Confina } \\
\text { ment }\end{array}$ & $\begin{array}{l}\text { XBTPV } \\
\text { MS }\end{array}$ & $\begin{array}{l}\text { soutro } \\
\text { Volumo } \\
\text { so HS }\end{array}$ & $\begin{array}{l}\text { rcon- } \\
\text { centra } \\
\text { do } M S\end{array}$ & $\begin{array}{l}\text { GPO } \\
\mathrm{Kg}\end{array}$ & $\begin{array}{l}\text { Conversäo } \\
\mathrm{Kg} \text { MS/ } \\
\mathrm{Kg} \text { GPD }\end{array}$ & $\begin{array}{c}\text { Consumo } \\
\text { MS } \\
\text { XPV }\end{array}$ & $\begin{array}{c}\text { Consumo } \\
\mathrm{MSP}_{\mathrm{g}}, \mathrm{K}^{9} \\
\mathrm{Py}\end{array}$ \\
\hline \multirow[t]{4}{*}{1} & 363 & 91 & 0 & 14.3 & 85,7 & 1,1 & 9,28 & 2,47 & \\
\hline & 363 & 91 & 14 & .- & 86 & 1,23 & 8,89 & 2,6 & \\
\hline & 366 & 91 & 30 & -. & 10 & 1,40 & 8,18 & 2,7 & \\
\hline & 365 & 91 & 45 & -. & 54 & 0,88 & 11,84 & 2,6 & \\
\hline \multirow[t]{4}{*}{2} & 324.5 & 12 & 42.6 & 26,8 & 30,6 & 0,96 & 10,33 & 2,8 & 120 \\
\hline & 329,6 & 12 & 52,2 & 17,5 & 30,3 & 0,816 & 12,25 & 2,8 & 121 \\
\hline & 332 & 12 & 61.6 & 8,6 & 29,8 & 0,87 & 11,62 & 2,8 & 122 \\
\hline & 333 & 12 & -. & 70,6 & 29,4 & 0,699 & 9,60 & 1,84 & 81,5 \\
\hline
\end{tabular}




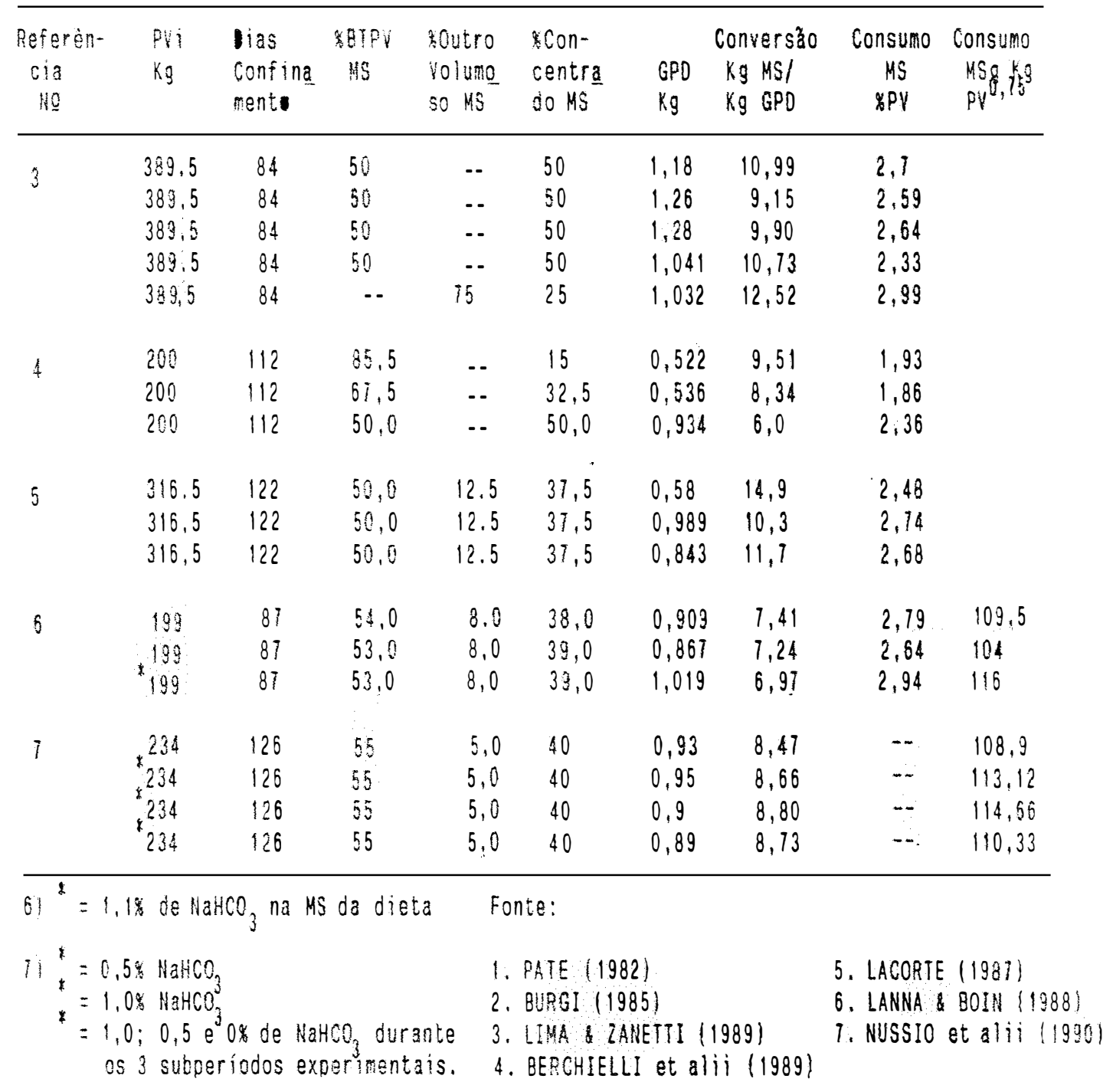

Para alguns conf inamentos comerciais, os dados obtidos em 1988 são sumarizados a seguir:

\begin{tabular}{lcccc}
\hline Indústria & $\begin{array}{c}\text { Dias } \\
\text { Confinamento }\end{array}$ & $\begin{array}{c}\text { Cons. MS } \\
\% \text { PV }\end{array}$ & $\begin{array}{l}\text { GPD } \\
\mathrm{Kg}\end{array}$ & $\begin{array}{c}\text { Conv } \\
\text { Alim. }\end{array}$ \\
\hline Alcidia & 112 & 3,07 & 0,986 & 11,73 \\
Vale Rosário & 112 & 2,16 & 0,993 & 8,8 \\
Pioneiros & 112 & 2,53 & - & -1, \\
Goianésia & 112 & 2,63 & 0.873 & 11,05 \\
Olho D'água & 98 & 2,99 & 1,12 & 10,0 \\
Itapetingui & 99 & 2,61 & 1,07 & 9,34 \\
\hline
\end{tabular}

Fonte: PLANO COUSULTORIA AGROPECUÁRIA (1989) 
Os dados apresentados mostram que resultados satisfatórios de desempenho animal podem ser obtidos com rações onde O BTPV representa 50 a $60 x$ da matéria seca. Como mencionado anteriormente, um aspecto que chama a atenção nos trabalhos realizados é o alto consumo de matéria seca obtido em dietas à base de BTPV, da ordem de 2,7 a $2,94 \%$ do peso vivo.

O tratamento do bagaço de cana-de-açúcar sob pressão de vapor altera a sua estrutura física, resultando em um alimento com particulas de tamanho reduzido, o que pode aumentar a taxa de passagem pelo rúmen, estimulando um maior consumo. Essa proposição pode ser observada no trabalho realizado por CASTRO (1989), que mostrou também que a taxa de passagem pós-rúmen é menor para o BTPV quando comparado ao bagaço "in natura" (BIN) em função de um menor estímulo ao peristaltismo intestinal. Sob o ponto de vista de aproveitamento da fração fibrosa do BTPV, a alta taxa de pasagem ruminal pode ser rejudicial, mas por outro lado, esta caracteristica pode favorecer a utilização do concentrado, que seria menos atacado no rúmen, e portanto digerido no instestino delgado (CASTRO, 1989).

Sendo - BTPV um alimento rico em componentes da parede celular, a sua utilização eficiente pelos ruminantes requer que a fração fibrosa seja degradada a nivel de rúmen. Portanto, um ambiente ruminal adequado à atividade das bactérias celuloliticas é fundamental, principalmente no 
que se refere a aspectos como pH, nivel de amonia, tempo de retenção, disponibilidade de isoácidos e outros fatores (BERGEN \& YOKOYAMA, 1977; BALDWIN \& ALLISON, 1983; OWENS \& GOETSCH, 1984; YOKOYAMA \& JOHNSON, 1985).

o crescimento de bactérias celuloliticas é bastante prejudicado quando o pH ruminal cai a valores inferiores a 6,0 (YOKOYAMA e JOHNSON, 1985). Diversos fatores podem afetar o pH ruminal, tais como a produção de saliva, produção e absorção de ácidos graxos voláteis (AGV) e o nivel de consumo (WHELLER, 198*). As caracteristicas físicas do alimento estimulando a ruminação e consequentemente a produção de saliva, o próprio pH do alimento e o teor de carboidratos solúveis rapidamente fermenteciveis, também podem afetar o pH ruminal (CASTRO, 1989).

Devido ao tratamento, o BTPV apresenta elevado teor de carboidratos solúveis e elevada acidez, com um valor de $\mathrm{pH}$ normalmente entre 2,8 a 3,6 (BURGI, 1987). Em função do tamanho reduzido de partícula e da sua alta friabilidade, o BTPV parece estimular uma baixa atividade de ruminação, resultando em baixa produção de saliva (CASTRO, 1989). Assim sendo, O BTPV poderá apresentar caracteristicas desfavoráveis à manutenção de um pH ruminal adequado à degradação da sua fração fibrosa. Os dados publicados por CostA (1987) confirmam estas suposições. Utilizando dietas à base de BTPV, o autor verificou que apesar do pH ruminal médio ser de 6,34, houve variação durante o dia, chegando os valores a 
permanecerem abaixo de 6, o por mais de 6 horas. CASTRO (1989) estudando a degradação da fraçÃo fibrosa do BTPV, verificou que o ambiente ruminal com dietas à base de BTPV foi inadequado à eficiente degradaçâo desta fração. Apesar do tratamento sob pressào de vapor elevar acentuadamente a "degradação potencial", a "degradação efetiva" do BTPV permaneceu muito baixa.

Técnicas que melhorem o ambiente ruminal, poderiam favorecer a atividade das bactérias celuloliticas e devem contribuir para aumentar a eficiência de utilização das dietas à base de BTPV por ruminantes. Segundo CASTRO (1989), apesar da elevada taxa de passagem ruminal do BTPV afetar de forma negativa a degradação da sua fração fibrosa, seria mais interessante procurar obter condições ruminais que aumentassem a taxa de degradação do BTPV ao invés de aumentar o tempo de retenção deste alimento no rúmen.

\subsection{Uso de agentes tamponantes}

\subsubsection{Consideraçôes gerais}

Um agente tamponante verdadeiro é um sal de um ácido fraco ou de um óxido ou hidróxido, que neutraliza acidos presentes nos alimentos ou ácidos produzidos durante a digesta e metabolismo dos nutrientes (STAPLES \& LOUGH, 1989). A caracterização de um agente tamponante é dada por seu pKa, ou seja, $\mathrm{opH}$ no qual metade dos seus grupos 
ionizáveis está ionizado. Agentes tamponantes com mais de um grupo ionizáve1 apresentam um número correspondente de valores de pka. O poder tamponante é máximo quando o pH do meio é igual ao pka do agente tamponante. Tais compostos oferecem resistência à variações de pH do meio dentro de mais ou menos uma unidade de pH do seu pKa (ARMENTANO \& SOLORZANO, 1988; STAPLES \& LOUGH, 1989).

Um agente tamonante verdadeiro deve evitar a queda do nH do meio sem causar a elevação deste, pois compostos que neutralizam ácidos, mas também elevam o pH não são agentes tamponantes verdadeiros, mas sim agentes alcalinizantes (ARMENTANO \& SOLORZANO, 1988; STAPLES \& LOUGH, 1989).

Compostos solúveis no rúmen, que apresentam um pka maior ou igual a 6,0, deveriam ser benéficos em dietas ricas em concentrados, como é o caso dos bicarbonatos. Bases fortes ou agentes tamponantes com pka maior que 7,0, quando usalos em doses elevadas, podem ocasionar uma elevação do pH ruminal acima dos niveis desejados (ARMENTANO \& SOLORZANO, $1988)$

Diversos agentes tamponantes e agentes alcalinizantes vêm sendo testados com a finalidade de melhorar o desempenho de animais ruminantes. Alguns compostos quimicos já comprovados como agentes tamponantes verdadeiros no fluido ruminal são: bicarbonato de sódio, bicarbonato de potássio, carbonato de magnésio, carbonato de cálcio e 
bentonita. Outros compostos como carbonato de sódio, carbonato de potássio, óxido de magnésio, hidróxido de sódio e hidróxido de cálcio, têm se mostrado eficientes agentes alcalinizantes (STAPLES \& LOUGH, 1989).

As informações abaixo sumarizadas apresentam a solubilidade e o poder tampão do bicarbonato de sódio (agente tamponante) e do carbonato de sódio (agente alcalinizante).

\begin{tabular}{lcc}
\hline Item & $\mathrm{Na}_{2} \mathrm{CO}_{3}$ & $\mathrm{NaHCO}_{3}$ \\
\hline Poder Tampão (emg/g) & 9,77 & 3,77 \\
Solubilidade (\%) & \\
20 Minutos & 48,89 & 55,14 \\
40 Minutos & 68,11 & 57,04 \\
60 Minutos & 56,58 & 56,72 \\
\hline
\end{tabular}

Fonte: BYERS at alii (1985)

2.2.2. Efeito sobre os parametros ruminais

o pH ruminal é função da produção de saliva, acidez da dieta, produção e absorção de ácidos graxos voláteis, nivel de consumo e troca de bicarbonato através do epitélio ruminal (WHEELER, 1980). A produção de saliva é essencial para a manutenção do $\mathrm{pH}$ ruminal dentro de niveis adeguados à atividade de bactérias celuloliticas. A ação tamponante da saliva se deve à ação de certos ânions como bicarbenato, fosfato e cloreto e certos cátions como sódio e 
potássio. A secreção de saliva deve ser contínua com a finalidade de evitar grandes variações no $\mathrm{pH}$ ruminal durante o dia. No entanto, o pH ruminal não permanece constante o dia todo, diminuindo rapidamente após a alimentação (WHEELER, $1980)$.

O fornecimento de dietas ricas em concentrados ou de dietas à base de BTPV + concentrado, tèm como característica um pequeno estímulo à ruminação, limitando a producão de saliva. Além disso, estimulam uma elevada produção de ácidos graxos voláteis, resultando em condições de pH ruminal desfavoráveis à ação das bactérias celuloliticas (WHEELER, 1980; CASTRO, 1989).

STAPLES \& LOUGH (1989), revisando um grande número de trabalhos de pesquisa realizados a partir de 1980 , sobre o uso de agentes tamponantes em dietas de vacas de leite, citaram que animais suplementados com bicarbonato de sódio $\left(\mathrm{NaHCO}_{3}\right)$ apresentaram maior $\mathrm{pH}$ ruminal e maior proporção de ácido acético ruminal, teores mais elevados de gordura no leite, e algumas vezes, digestibilidade maior da fibra que animais controle

Trabalhos conduzidos com animais em crescimento e terminação têm mostrado o efeito tamponante do bicarbonato de sódio no rúmen (WHEELER et alii, 1981b; OKEKE et al ii, 1983; BYERS et alii, 1985; STROUD et al ii, 1985; TEH et alii, 1985; KVACIK et alii, 1986; BOERNER et alii, 1987b). Os dados apresentados a seguir sugerem que, com 
animais em crescimento e terminação, o pH ruminal é afetado pelo uso de $\mathrm{NaHCO}_{3}$ somente quando o nivel de concentrado na dieta é elevado, ou seja, superior a $60 \%$.

\begin{tabular}{|c|c|c|c|c|c|c|c|c|c|c|}
\hline \multirow{2}{*}{$\begin{array}{l}\text { Refe- } \\
\text { ren- } \\
\text { cia }\end{array}$} & \multirow{2}{*}{$\begin{array}{l}\text { Concen } \\
\text { trado } \\
\text { * na us }\end{array}$} & \multirow{2}{*}{$\begin{array}{c}\mathrm{HaHCO}_{3} \\
\text { \& } \\
\text { na } \mathrm{MS}\end{array}$} & \multirow{2}{*}{$\begin{array}{l}\text { DH } \\
\text { rúmen }\end{array}$} & \multicolumn{2}{|c|}{ taxa de passagem } & \multirow{2}{*}{$\begin{array}{c}C 2 \\
* \\
\text { Molar }\end{array}$} & \multirow[t]{2}{*}{ C3 } & \multicolumn{3}{|c|}{$\begin{array}{c}\text { Digestibilidade no trato } \\
\text { Digestivo Tota! }\end{array}$} \\
\hline & & & & Sólido & Líquido & & & MS & ADF OU NDF & Aniogo \\
\hline & 91 & ---- & 6,6 & ---- & ---- & 50,8 & 32,3 & --- & ---- & 59 \\
\hline & 91 & 0,9 & 6.7 & ---- & --- & 50,6 & 33,4 & --- & --- & 60 \\
\hline & 85 & --- & $5,84_{h}^{a}$ & ---- & --- & $49,2_{h}^{a}$ & $36,6^{a}$ & 66,2 & $62,1^{a}$ & $85,4_{h}^{b}$ \\
\hline$\hat{\imath}$ & 85 & 0.75 & $6,11^{0}$ & ---- & --- & $45,5^{D}$ & 41,10 & 66,5 & $62,8^{8}$ & $B 4, Q^{D}$ \\
\hline & 85 & 1,50 & $6,30^{\circ}$ & ---- & --- & $44,2^{0}$ & $41,9^{0}$ & 66,8 & $64,9^{\mathrm{c}}$ & $83,0^{3}$ \\
\hline & 50 & 0 & a & $5,3^{a}$ & $6,2^{2}$ & a & ---- & ---- & --- & --- \\
\hline 3 & 50 & 0,75 & $a$ & $5,3^{d}$ & $6,2_{b}^{a}$ & a & ---- & ---- & ---- & ---- \\
\hline & 50 & 2,50 & $b$ & $6,5_{0}^{0}$ & 8,30 & b & ---- & ---- & ---- & ---- \\
\hline & 50 & 5.0 & $b$ & $6,6^{0}$ & $8,4^{\circ}$ & b & ---- & --- & --- & --- \\
\hline & $8 \hat{80}$ & 0 & a & $5,0^{a}$ & $6.3^{7}$ & a & ---- & --- & --- & --- \\
\hline 4 & 80 & 0.75 & a & $5,0_{b}^{3}$ & $6.4^{a}$ & a & --- & --- & --- & --- \\
\hline & 80 & 2,50 & $b$ & $6,6^{0}$ & $8.9^{0}$ & b & ---- & ---- & ---- & ---- \\
\hline & 80 & 5.0 & $b$ & $6,7^{0}$ & $9,0^{0}$ & b & ---- & ---- & ---- & ---- \\
\hline 5 & 85 & 0 & 6,2 & ---- & 14,0 & --- & --- & $-\quad 61,3$ & 33,7 & 94.2 \\
\hline & 85 & 1,0 & 6,3 & ---- & 13,5 & ---- & ---- & $-61,6$ & 33,7 & 93.0 \\
\hline 6 & 84 & 0 & 6,17 & ---- & --- & ---- & ---- & $74,5_{\mathrm{b}}^{\mathrm{a}}$ & 74,5 & 98,6 \\
\hline & 84 & 1,75 & 6,64 & ---- & ---- & ---- & ---- & $\quad 76,9^{0}$ & 79,0 & 97,8 \\
\hline 7 & 87.7 & 0 & $5.4^{a}$ & ---- & ---- & 53,9 & 32,4 & $17,9_{h}^{a}$ & $49,2_{h}^{a}$ & 94,9 \\
\hline & $B 4,0$ & 1,0 & $5,7^{\circ}$ & ---- & ---- & 53,9 & 30,3 & $84,6^{\circ}$ & $66,9^{0}$ & 95,4 \\
\hline & 50 & 0 & a & 3,1 & 5,5 & ---- & ---- & 11,2 & 58,8 & ---- \\
\hline 8 & 50 & 1.5 & t & 2,4 & 5,8 & ---- & ---- & 11,8 & 60,5 & --- \\
\hline & 50 & 3.0 & 6 & 4,7 & 6.7 & ---- & ---- & 71,7 & 60,1 & ---- \\
\hline & 50 & 4,5 & 0 & 2.9 & 5.4 & ---- & ---- & 12,5 & 61,8 & ---- \\
\hline & 50 & 0 & $6,66^{2}$ & $3,7^{\mathrm{a}}$ & $8,7^{2}$ & $66,9^{a}$ & $18,4^{a}$ & $57,0^{2}$ & $51,5^{2}$ & $78,8^{2}$, \\
\hline 9 & 50 & 1,0 & $6,62_{f}^{\mathrm{z}}$ & $3,9_{f}^{2}$ & $8,5_{f}^{2}$ & $67,4^{\mathrm{a}}$ & $18,1_{f}^{\mathrm{a}}$ & $56,8_{f}^{\mathrm{a}}$ & $49,3^{a} f$ & $78.0_{f}^{3}$ \\
\hline & 16 & 0 & 6.76 & 3,4 & $7,4_{f}^{i}$ & $67,0_{f}$ & $19,5_{f}^{1}$ & $57,6_{f}^{1}$ & $52,2 \mathrm{f}$ & $84,1_{f}$ \\
\hline & 16 & 1,0 & $6,80^{\circ}$ & $3,6^{7}$ & $7,8^{7}$ & $67,2^{7}$ & $19,1^{\top}$ & $56,8^{\top}$ & $49,9^{\gamma}$ & $8 \hat{2}, \hat{B}^{1}$ \\
\hline & 90 & 0 & ---- & ---- & ---- & a & a & $70,8^{a}$ & 38,1 & 87.8 \\
\hline 10 & 98 & 1,0 & ---- & ---- & ---- & a & $b$ & $11,8^{\mathrm{a}}$ & 49,0 & 90.1 \\
\hline & 50 & 0 & ---- & ---- & ---- & a & $c$ & $52,6^{\circ}$ & 47,5 & 18,5 \\
\hline & 50 & 1.0 & ---- & ---- & ---- & a & cod & $59,9^{8}$ & 42,5 & 81,6 \\
\hline
\end{tabular}




\begin{tabular}{|c|c|c|c|c|c|c|c|c|c|c|}
\hline \multirow{2}{*}{$\begin{array}{l}\text { Refe- } \\
\text { ren- } \\
\text { cia }\end{array}$} & \multirow{2}{*}{$\begin{array}{l}\text { concen } \\
\text { trado } \\
\text { in na MS }\end{array}$} & \multirow{2}{*}{$\begin{array}{c}\mathrm{NaHCO}_{3} \\
* \\
\text { ná } \\
\mathrm{MSS}^{2}\end{array}$} & \multirow{2}{*}{$\begin{array}{l}\text { pH } \\
\text { rúmęn }\end{array}$} & \multicolumn{2}{|c|}{ taxa de passagem } & \multirow{2}{*}{${ }^{C 2} \underset{*}{*}$} & \multirow[t]{2}{*}{ C3 } & \multicolumn{3}{|c|}{$\begin{array}{c}\text { Digestibilidade no trato } \\
\text { Digestivo Total }\end{array}$} \\
\hline & & & & Sólido & Liquido & & & MS & ADF OU NDF & Amido \\
\hline \multirow[t]{3}{*}{11} & 60 & 0 & 6,46 & 4,5 & 6.48 & ---- & ---- & ---- & ---- & \\
\hline & 50 & 0.8 & 6,46 & 4,9 & 3,24 & --- & --- & --- & ---- & --- \\
\hline & 50 & 0 & 5,8 & --- & -- & a & 8 & $52,6_{h}^{\mathrm{a}}$ & 47,5 & 78,5 \\
\hline \multirow[t]{3}{*}{12} & 50 & 1,0 & 5.8 & --- & --- & a & a & $59,9^{\circ}$ & 46,2 & 81,6 \\
\hline & 90 & 0 & $5,55_{h}^{\mathrm{a}}$ & ---- & --- & $f$ & f & 70,8 & 38,1 & 87.8 \\
\hline & 90 & 1,0 & $5,61^{0}$ & ---- & ---- & 9 & $f$ & 71,8 & 49,0 & 90,1 \\
\hline \multirow[t]{2}{*}{13} & 50 & 0 & $6,48_{h}^{\mathrm{a}}$ & ---- & 6.63 & 59,5 & 15,3 & ---- & ---- & -- \\
\hline & 60 & 1,0 & $6,66^{\circ}$ & --- & 5,32 & 58,1 & 16,1 & ---- & --- & -- \\
\hline
\end{tabular}

$a, b, c, d$ na mesma coluna médias seguidas de letras diferentes diferem entre si $(P \leq 0,05)$.

- $f, g$ na mesma coluna médias seguidas de letras diferentes diferem entre si $(P \leq 0,05)$.

1. RUSSELL et alii (1980) 8. KOYACIK et alii (1986)

2. HEELER et alii (19816) 9. JACQUES et alii (1986)

3. OKEKE et alii (1983) 10. BOERNER et aic (1987a)

4. OKEKE et alii (1983) 11. TEH et alii (1987)

5. PEIRCE et aln 11983$)$ 12. ByERS et alif (1985)

6 . JBNES e WOHLT (1985) 13. TEH et alii (1985)

i. STROUD et alli (1985)

Quando o bicarbonato entra no rúmen, ele reage com $\mathrm{H}_{3} \mathrm{O}^{+}$dando $\mathrm{H}_{2} \mathrm{CO}_{3}+\mathrm{H}_{2} \mathrm{O}$ elevando assim pH. No entanto o valor de pH do equilibrio:

$$
\mathrm{HCO}_{3}^{-}+\mathrm{H}_{3} \mathrm{O}^{+} \leftrightarrow\left[\mathrm{H}_{2} \mathrm{CO}_{3}+\mathrm{H}_{2} \mathrm{O}\right] \longleftrightarrow-\mathrm{CO}_{2}+2 \mathrm{H}_{2} \mathrm{O}
$$

é 6,25 , o que leva a concluir que bicarbonato só terá um pape 1 importante como agente tamponante se o pH ruminal for 6,25 ou mais baixo (COUNOTTE et alii, 1979).

A adição de agentes tamponantes em dietas normalmente utilizadas para vacas de leite de alta produçăo, onde o nivel de concentrado tem variado de 50 a $60 \%$ da matéria seca, tem resultado em aumento da porcentagem molar de ácido acético e reduçăo na porcentagem molar de ácido 
propionico (DIVEN, 1975a; STAPLES \& LOUGH, 1989). Entretanto, essa tendência muitas vezes não é verificada em rações para yado de corfe, onde o nivel de concentrado é superior a $80 \%$ da matéria seca, sendo verificado redução de ácido acético e elevação de ácido propiônico (DIVEN, 1975a). A produçăo total de ácidos graxos voláteis parece ser pouco afetado pelo uso de agentes tamponantes (DIVEN, 1975a).

A adição de soluções com elevada pressão osmótica tem geralmente elevado a taxa de passagem ruminal de fluidos. Solutos derivados dos alimentos, da saliva e os produtos da fermentação devem elevar a taxa de passagem ruminal de fluidos (OWENS \& GOETSCH, 1984). A elevada taxa de passagem ruminal do BTPV verificada por CASTRO (1989), foi apontada pelo autor como um fator prejudicial à sua degradabi 1 idade.

o uso de agentes tamponantes pode acelerar a taxa de passagem rumina1. No entanto, segundo STAPLES \& LOUGH (1989), isto só ocorre quando níveis elevados são utilizados. Niveis de bicarbonato de sódio entre 0,8 a $1,0 \%$ da matéria seca da dieta normalmente não provocam alterações na cinética de fluidos e sólidos ruminais, de acordo com os dados publicados por OKEKE et alii (1983); PEIRCE et alii (1983); KOVACIK et alii (1986); JACQUES et alii (1986); TEH et alii (1985); TEH et alii (1987); STAPLES E LOUGH (1989).

A adição de bicarbonato de sódio em dietas de ruminantes poderia favorecer a degradação da fracão fibrosa 
dos alimentos a nivel de rúmen, mas os resultados de pesquisa não permitem uma conclusăo definitiva sobre o assunto (WHEELER et a Tii, 1981b; PEIRCE et alii, 1983; JAMES e WOHLT, 1985; BYERS et alii, 1985; STROUD et alii, 1985; KOVACIK et a $1 \mathrm{i} i, 1986$; JACQUES et a $7 \mathrm{i}$, 1986; BOERNER et alii, 1987a). DIVEN (1975a) afirmou haver pouco ou nenhum efeito de agentes tamponantes na digestibilidade dos alimentos.

A baixa degradação ruminal da fração fibrosa do BTPV deve-se principalmente a um ambiente ruminal desfavorável, em termos de pH (CASTRO, 1989). FRANCISCO Jr. \& MACHADO (1990), trabaihando com niveis crescentes de uréia em rações à base de BTPV, obtiveram elevação significativa dos niveis de amônia e pH ruminal, resultando em maior degradaçăo da fração fibrosa do BTPV, indicando que deficiências de nitrogênio também são responsáveis pela pequena ação de microrganismos.

A amônia é a principal fonte de nitrogênio para as bactérias do rúmen que, na presença de cadeias carbonicas, pintetizam os aminoácidos necessários para o seu próprio uso. Acredita-se que 5 a $7 \mathrm{mg}$ de $\mathrm{N}-\mathrm{NH}_{3} / 100 \mathrm{ml}$ de fluido ruminal sejam requeridas para maximizar a sintese de proteina microbiana de acordo com a revisão apresentada por TAMMNIGA (1979) e BONDI (1981). Entretanto, TAMMINGA (1979) relatou que eutros autores, verificaram que taxas máximas de fermentação ruminal foram obtidas com niveis de $23,5 \mathrm{mg}$ de $\mathrm{N}$ $\mathrm{NH}_{3} / 100 \mathrm{ml}$ de fluido ruminal. 
A elevação do $\mathrm{pH}$ ruminal, através da ação de agentes tamponantes, poderia elevar a solubilidade da proteina, favorecendo a sintese de proteina microbiana e a digestão de fibra de acordo com citacões de ARMENTANO \& SOLORZANO (1988) e TEH et alii (1987).

A ação de agentes tamponantes sobre a disponibilidade de amônia no rúmen é controvertida, pois a adisăo de bicarbonato de sódio em niveis entre 0,8 a $1,5 \%$ da matéria seca da dieta de novilhos em crescimento não alterou o nível de amônia no rúmen (WHEELER et a1ii, 1981b; HAALAND \& TYRRELL, 1982; TEH et alii, 1987), mas outros trabaihos têm mostrado redução do nivel de amônia com a adição dessas substâncias (HAALAND et alii, 1982; TEH et alii, 1985).

\subsubsection{Efeito no trato digestivo inferior}

A manutenção de um pH intestinal próximo da neutralidade vem sendo objeto de estudo de diversos pesquisadores, pois alguns dados de pesquisa têm mostrado que a adi̧̧ão de agentes tamponantes pode afetar a digestão do amido e da proteina no trato digestivo inferior (WHEELER, 1980; WHEELER et a $1 \mathrm{i} i, 1981 \mathrm{~b}$; TEH et alii, 1985; TEH et alii, 1987; CHRISTIANSEN \& WEBB, 1987/88). A e levação do pH intestinal para niveis próximos da neutralidade favorece a ação da enzima alfa-amilase pancreática, responsável pela digestão do amido e de diversas enzimas proteoliticas 
secretadas no intestino delgado de ruminantes (WHEELER, 1980). CHRSTIANSEN \& WEBB (1987/88) verificaram um efeito favorável de agentes tamponantes na utilização da proteína por novithos confinados, através de um maior fluxo de proteína para o duodeno e de aumento na absorção de aminoácidos como isoleucina, leucina, valina, alanina e ácido aspártico.

o bicarbonato de sódio parece ter pouco efeito a nivel de intestino, agindo principalmente como um agente tamponante ruminal (DIVEN, 1975b; WHEELER et a $1 \mathrm{i} i$, 1981b; TEH et alii, 1985; TEH et alii, 1987), enquanto o óxido de magnésio pode agir tanto a nivel de rúmen como de intestino (PEIRCE et alii, 1983; JAMES e WOHLT, 1985; TEH et a) ii, 1985; STROUD et alii, 1985; TEH et alii, 1987). O calcário tem sido citado frequentemente como um agente tamponante eficiente a nivel de intestino (WHEELER, 1980; WHEELER et a $1 \mathrm{i}, 1981 \mathrm{a}$; HAALAND \& TYRRELL, 1982; HAALAND et a $\mathrm{i} i, 1982$; TEH et alii, 1985). Entretanto, alguns trabalhos têm mostrado que calcários de alta reatividade podem também agir a nivel de rumen (WHEELER et alii, 1981b; HAALAND et alii,1982; TEH et a 111,1985$)$.

Além da elevação do pH ruminal e intestinal, os agentes tamponantes podem também estimular a secreção do abomaso do pancreas, afetando a digestão dos alimentos (TEH et alit, 1985; TEH et alii, 1987). O abomaso de ruminantes assemelha-se bastante ao estomago dos monogástricos na sua 
capacidade de secretar ácido cloridrico e pepsina, apresentando um pH entre 2,0 a 3,0 WHEELER (1980). A adiçăo de agente tamponante na dieta, poderia ocasionar uma maior liberação de ácido cloridrico pelo abomaso na tentativa de manter o pH entre 2,0 a 3,0 , em função tanto do efeito do agente tamponante como devido a um maior fluxo de aminoácidos para o duodeno. O ácido clorídrico parece ser um importante estimilante da secerea a pancreática no duodeno. Assim, uma maior secręúo do abomaso, poderia resultar em maior secreção pancreática, aumentando a digeståo intestinal dos alimentos (TEH et alir, 1985; TEH et alii, 1987).

\subsubsection{Efeito sobre o desempenho animal}

Dos 40 trabaihos revisados por STAPLES \& LOUGH (1989), sobre o uso de bicarbonato de sódio, 28 utilizaram silagem de milho como volumoso básico, havendo efeito positivo na produção de leite, teor de gordura e leite corrigido para $4 \%$ de gordura em vacas tanto no inicio como no meio da lactação. Vacas recebendo bicarbonato de sódio parecem perder mais peso no início da lactação, havendo uma reversã deste efeito a partir do meio da lactação. A maior produção de leite corrigido para $4 \%$ de gordura durante 0 inicio da lactação e o maior ganho de peso durante o meio da lactação, podem estar relacionados a um maior consumo de matéria seca quando bicarbonato de sódio é fornecido. Os 
dados compilados sobre o efeito de bicarbonato de sódio, mostram que além do nível de concentrado, o tipo de volumoso utilizado tem influência no efeito deste agente tamponante. Alimentos ácidos como silagens, parecem ter seu consumo aumentado quando bicarbonato de sódio é adicionado. Os autores concluiram que o melhor efeito do bicarbonato de sódio é obtido quando este é utilizado ao nivel de $0,75 \%$ da matéria seca da dieta, sendo esta dieta constituida de 40-50\% de silagem de milho e 50-60\% de concentrado.

$$
\text { Dentre os fatores que podem ser responsáveis }
$$

pelo efeito positivo do uso de agentes tamponantes podem ser incluidos:

a) Maior consumo de matéria seca (STAPLES \& LOUGH, 1989)

b) Melhor condição ruminal para a atividade microbiana (DIVEN, 1975a; WHEELER, 1980; ARMENTANO \& SOLORZANO, 1988; STAPLES \& LOUGH, 1989).

c) Melhor condição de $\mathrm{pH}$ intestinal e maior secreção gástrica e pancreática, afetando a digestão e absorção dos nutrientes (WHEELER, 1980; WHEELER et a1ii, 1981b; TEH et aTii, 1985; TEH et a Tii, 1987).

d) Influência no balanço ácido-básico (KRONFELD, 1978; ROBY et alii, 1987).

e) Influência no balanço de eletrólitos (KRONFELD, 1978; Mony et a (ii, 1987).

A adịão de bicarbonato de sódio à dieta pode reduzir a excreção urinária de cálcio, fósforo e magnésio, 
favorecendo o desempenho de animais em crescimento, reduzindo - problema de cálculos renais e a ocorrência de hipocalcemia em animais adultos. A maior retenção de cálcio pode ajudar na prevenção de distúrbios como paresia pós parto, tetania da lactação, distocia e retenção de placenta (ROBY et alii, $1987)$.

Foram conduzidos estudos com a finalidade de se avaliar o efeito de agentes tamponantes na concentração de metabólitos hormonais no plasma, principalmente somatotropina. Os mecanismes de açăo da somatotropina e do blcarbonato de sódi parecem ser independentes um do outro, ou seja, o fornecimento de bicarbonato de sódio provavelmente não tem efeito sobre a digestão e metabolismo via sistema endócrino (STAPLES \& LOUGH, 1989).

os resultados de desempenho animal com o uso de agentes tamponantes para animais em crescimento e engorda são bastantes variáveis, dificultando uma conclusão segura e definitiva sobre o assunto. Diversos trabalhos comprovando a atuação desses agentes a nivel fisiológico e metabólico sugerem efeito positivo no desempenho, em termos de ganho de peso e conversã alimentar.

DIVEN (1975b), revisando o assunto, afirmou que a utilização de agentes tamponantes aumentou a taxa de ganho de peso e a eficiência alimentar nos casos onde houve elevação de consumo, havendo dados onde a eficiência a Timentar foi aumentada sem elevação no consumo, e dados 
mostrando efeitos negativos no desempenho animal, quando o nivel fornecido do agente tamponante foi muito elevado.

$$
\text { o dados a seguir apresentam alguns resultados }
$$
da utilização de agentes tamponantes para animais em crescimento e engorda.

\begin{tabular}{|c|c|c|c|c|c|c|c|}
\hline $\begin{array}{c}\text { Fafserencia } \\
110\end{array}$ & $\begin{array}{l}\text { Concetrado } \\
\text { s na MS }\end{array}$ & $\begin{array}{l}\text { Agente } \\
\text { Tamponante } \\
\text { Tipo }\end{array}$ & \& na MS & $\begin{array}{l}C O O N S \\
K g \text { MS }\end{array}$ & $\begin{array}{l}\forall \text { III } 0 \\
x \mathrm{PV}\end{array}$ & $\begin{array}{l}\text { GPO } \\
k g\end{array}$ & $\begin{array}{l}\text { Conversão } \\
\text { Alimentar }\end{array}$ \\
\hline$i$ & $\begin{array}{l}91 \\
91 \\
91 \\
91\end{array}$ & $\begin{array}{c}\mathrm{MaHCO}_{3} \\
\mathrm{Calcário} \\
\mathrm{NaHCO}_{3}+\mathrm{Calc} .\end{array}$ & $\begin{array}{c}0,9 \\
1,8 \\
0,9+1,8\end{array}$ & $\begin{array}{r}10,03 \\
10,12 \\
9,62 \\
9,70\end{array}$ & $\begin{array}{l}- \\
- \\
-\end{array}$ & $\begin{array}{l}1,34^{a} \\
1,32^{a} \\
1,27^{a b} \\
1,18^{b}\end{array}$ & $\begin{array}{l}7.55 \\
7.13 \\
7.81 \\
8.23\end{array}$ \\
\hline $2^{*}$ & $\begin{array}{l}85 \\
85\end{array}$ & $\begin{array}{l}\text { Calcário B } \\
\text { Calcário A }\end{array}$ & $\begin{array}{l}1,6 \\
1,8\end{array}$ & $\begin{array}{l}9,3^{\mathrm{a}} \\
9,5^{b}\end{array}$ & 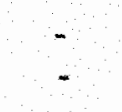 & $\begin{array}{l}1,04^{\mathrm{a}} \\
1,34^{\mathrm{b}}\end{array}$ & $9,4^{2}$ \\
\hline 3 & $\begin{array}{l}85 \\
85 \\
85 \\
85 \\
85 \\
85\end{array}$ & $\begin{array}{c}\text { Calcário A } \\
\text { Calc. A + } \mathrm{NaHCO}_{3} \\
\text { Caic. A + } \mathrm{NaHCO}_{3} \\
\text { Caicárió A } \\
\text { Calc. A + } \mathrm{NaHCO}_{3} \\
\text { Calc. A + } \mathrm{NaHCO}_{3}\end{array}$ & $\begin{array}{c}0,7 \\
0,7+0,75 \\
0,7+1,5 \\
1,7 \\
1,7+0,75 \\
1,7+1,5\end{array}$ & $\begin{array}{c}10,1^{b} \\
10,1^{b} \\
9,2^{a} \\
10,7^{b} \\
10,8^{b} \\
9,1^{a}\end{array}$ & $\begin{array}{l}- \\
- \\
- \\
-\end{array}$ & $\begin{array}{l}1,3^{b} \\
1,26^{b} \\
0,97^{a} \\
1,52^{c} \\
1,43^{c} \\
0,94^{a}\end{array}$ & $\begin{array}{l}7.8^{b} \\
8.2^{b} \\
9.5^{a} \\
7.1^{c} \\
3.4^{\circ} \\
9.7^{2}\end{array}$ \\
\hline 4 & $\begin{array}{l}85 \\
85 \\
85 \\
85\end{array}$ & $\begin{array}{c}\text { Controle } \\
\mathrm{H}_{3} \mathrm{O} \\
\mathrm{NaHCO}_{3} \\
\mathrm{NaHCO}_{3}+\mathrm{N}_{3} \mathrm{O}\end{array}$ & $\begin{array}{c}- \\
0.5 \\
1,0 \\
1.1+0.5\end{array}$ & $\begin{array}{l}7,0^{2} \\
8,0^{2} \\
8,5^{8} \\
7,7^{8}\end{array}$ & $\begin{array}{l}2,04^{a} \\
2,18^{a} \\
2,39^{b} \\
2,07^{2}\end{array}$ & $\begin{array}{l}- \\
- \\
-\end{array}$ & $\begin{array}{l}- \\
-\end{array}$ \\
\hline $5^{5 *}$ & $\begin{array}{l}84 \\
84 \\
84 \\
84 \\
84\end{array}$ & $\begin{array}{l}- \\
\text { Macl } \\
\mathrm{MgO} \\
\mathrm{HaHCO} \\
\text { Calcário }\end{array}$ & $\begin{array}{l}- \\
0,52 \\
0,18 \\
0,75 \\
0,47\end{array}$ & $\begin{array}{l}1,081 \\
1,123 \\
1,150 \\
1,099 \\
1,085\end{array}$ & $\begin{array}{l}- \\
- \\
-\end{array}$ & $\begin{array}{l}0,22 \\
0,216 \\
0,231 \\
0,231 \\
0,227\end{array}$ & $\begin{array}{l}- \\
- \\
- \\
-\end{array}$ \\
\hline 6 & $\begin{array}{l}87, i \\
84,0 \\
84,0\end{array}$ & $\mathrm{NaHCO}_{3}$ & $\frac{-}{1,0}$ & $\begin{array}{r}9,95 \\
10,18 \\
9,67\end{array}$ & - & $\begin{array}{l}1,3 \\
1,45 \\
1,40\end{array}$ & $\begin{array}{l}1,15 \\
1,01 \\
6,91\end{array}$ \\
\hline 1 & $\begin{array}{l}50 \\
50 \\
50\end{array}$ & $\begin{array}{l}\text { NaHCO } \\
\text { Bentonita }\end{array}$ & $\begin{array}{c}0 \\
1,0 \\
2,0\end{array}$ & $\begin{array}{l}7,7^{f} \\
8,3^{9} \\
7,5^{f}\end{array}$ & 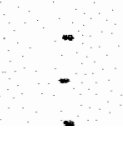 & - & - \\
\hline
\end{tabular}




\begin{tabular}{|c|c|c|c|c|c|c|c|}
\hline $\begin{array}{l}\text { Referénció } \\
\text { Mo }\end{array}$ & $\begin{array}{l}\text { Concetrajo } \\
\text { * na MS }\end{array}$ & $\begin{array}{l}\text { Sgente } \\
\text { Tamponante } \\
\text { Tipo }\end{array}$ & 8 na MS & $\begin{array}{lll}C & O & n \\
\mathrm{Kg} & M S\end{array}$ & $\begin{array}{l}U \text { I m } 0 \\
x \quad P V\end{array}$ & $\begin{array}{l}\text { GPD } \\
k g\end{array}$ & $\begin{array}{l}\text { Conversão } \\
\text { Alimentar }\end{array}$ \\
\hline 8 & $\begin{array}{l}90 \\
90 \\
90\end{array}$ & TROHCO & $\begin{array}{l}- \\
1,0 \\
1,0\end{array}$ & $\begin{array}{l}6,4 \\
6,3 \\
6,3\end{array}$ & $\begin{array}{l}- \\
-\end{array}$ & $\begin{array}{l}- \\
-\end{array}$ & $\begin{array}{l}- \\
- \\
-\end{array}$ \\
\hline 8 & $\begin{array}{l}50 \\
50 \\
50\end{array}$ & $\mathrm{NaHCO}$ & $\begin{array}{l}1,0 \\
1.0\end{array}$ & $\begin{array}{l}6,5 \\
6,5 \\
6,4\end{array}$ & - & - & - \\
\hline 9 & $\begin{array}{l}90 \\
90\end{array}$ & $\mathrm{HaHCO}$ & 1,0 & - & $\begin{array}{l}2,9 \\
3,1\end{array}$ & $\begin{array}{l}1,16 \\
1,04\end{array}$ & $\begin{array}{l}7,9 \\
8,7\end{array}$ \\
\hline
\end{tabular}

$3, b, c, d$ na mesma coluna médias seguidas de letras diferentes diferem entre si $(P \leq 0.05)$.

- $\{. g$ na mesma coluna médias seguidas de letras diferentes diferem entresi $(P \leq 0,01)$.

- Calcário $A$ = alta reatividade, $B$ = baixa reatividade

Excermento conduzido com ovinos

1. Russel et alii (1080) 6. STROud et alii l1985)

2. WHEELER et alii (1981a) T JACQUES et alii (1980)

3. HEELER at alii (1381b) 8. BOERHER at alii (1987a)

4. PETRCE alii (1983) 9. Biens et alif (1985)

5. DAMES \& NOHLT (1985)

\subsection{Uso de ionóforos}

\section{$2 \cdot 3,1$. Consideraçōes gerais}

A utilização de substâncias que estimulam o crescimento vem sendo estudada intensamente, com o objetivo de aumentar a produção anima1, seja através de um aumento na quantidade ou qualidade dos nutrientes disponfveis aos tecidos animais ou de um aumento na eficiência com a qual estes nutrientes são utilizados (CHALUPA, 1977; MACHADO \& MADEIRA, 1990).

Em ruminantes, a manipulação da fermentação ruminal com o objetivo de aumentar a quantidade e ou a 
qualidade dos nutrientes disponiveis ao animal, através de alterações na proporção de ácidos graxos voláteis, redução das perdas via metano e melhor aproveitamento da proteína da dieta, pode ser conseguida com a utilização de ion foros (BERGEN \& BATES, 1984; RUSSELL \& STROBEL, 1989; STROBEL et alii, 1989).

Ionóforos são moléculas que contém uma estrutura onde átomos de oxigênio espaçados estratégicamente em anéis ou cavidade, 1igam-se a diferentes cátions (CHALUPA, 1980), servindo como transportadores destes ions através da mebrana celular (BERGEN \& BATES, 1984). Os ionóforos são produzidos por várias linhagens de streptomices (BERGEN \& BATES, 1984). Dentro deste grupo de compostos incluem-se: monensina, lasalocida, salinomicina e narasina (SCHELLING, 1984; BERGEN \& BATES, 1984), tetronasina, 1isocelina e laidlomicina (RUSSELL \& STROBEL, 1989).

o uso de ionóforos na dieta de ruminantes foi aprovado nos Estados Unidos da América em meados da década de setenta, e desde então vêm sendo utilizados intensamente, principalmente nos confinamentos de gado de corte (RUSSELL \& STROBEL, 1989). Caso todos os bovinos confinados para a produção de carne nos Estados Unidos da América, recebessem $350 \mathrm{mg}$ de monensina por cabeca por dia, durante 140 dias, a despesa anual com este ionóforo seria da ordem de setenta milhōes de dólares e considerando uma eficiência de $8: 1,0$ beneficio total seria da ordem de 560 milhões de dólares 
(RUSSELL \& STROBEL, 1989).

SCHELLING (1984), propôs 7 modos de ação através dos quais a monensina, o ionóforo mais estudado, me lhora o desempenho animal:

a) Alteração na produção de ácidos graxos voláteis ( $A G V$ ).

b) Alteração no consumo de alimentos.

c) Alteraçấo na produção de gases.

- Alteraça na digestibilidade dos alimentos.

e) Alteraçăo no enchimento do rúmen e taxa de passagem.

f) Alteraça na utilização da proteína.

g) Outros modos de ação ruminal.

$$
\text { os itens acima citados dão ênfase }
$$

principalmente à ação dos ionóforos a nivel de rúmen e são enfatizados em diversas revisões sobre o assunto (BERGEN \& BATES, 1984; RUSSELL \& STROBEL, 1989). Entretanto já sé sabe que a ação dos ionóforos não se limita aos microrganismos do rúmen, podendo afetar diretamente o metabolismo do ruminante (ARMSTRONG \& SPEARS, 1988; BENZ et alii, 1989), já que parte do ionóforo é absorvido pelo organismo animal (ARMSTRONG \& SPEARS, 1988).

As principais alterações observadas na fermentação ruminal com o uso de ionóforos deve-se à ação seletiva destes compostos sobre a população microbiana do rúmen. De modo geral, bactérias gram-positivas são mais sensiveis aos ionóforos que as gram-negativas. Bactérias celuloliticas como Ruminococcus albus, Ruminococcus 
flavefaciens, algumas linhagens de Butyrivibrio fibrisolvens e bactérias láticas como streptococcus bovis, são bastante sensiveis aos ionóforos. Bacteroides succinogenes e Bacteroides ruminicola são menos sensiveis, enquanto Selenomonas ruminantium são bastante resistentes aos ionóforos (BERGEN \& BATES, 1984; RUSSELL \& STROBEL, 1989).

A sensibilidade ou não das bactérias ruminais aos ionóforos parece estar relacionada à presença ou ausência de uma membrana externa de revestimento e à ocorrência de fosforilação oxidativa através da enzima fumarato redutase. BERGEN \& BATES (1984) enfatizaram a ocorrência da foşforilação oxidativa via fumarato redutase como fator mais importante para a resitência das bactérias aos ionóforos, enquanto RUSSELL \& STROBEL (1989) atribuiram a presença da membrana externa nas bactérias resistentes como o fator mais importante.

2.3.2. Mecanismo básico de ação dos ionóforos sobre os microrganismos ruminais.

Por serem os ionóforos substâncias capazes de interagir estequiométricamente com ions metálicos, funcionando como transpertadores de ions através da membrana celular, qualquer análise sobre a ação dos ionóforos deve considerar sums interaçôes com as membrans biológicas (BERGEN \& BATES, 1984 ) . 
Ionóforo carboxílico, como a monensina, localizado na interface da membrana na forma anionica, ligase a um cátion metálico, formando um complexo capaz de se difundir através da membrana celular. Dessa forma ele atinge a face oposta da membrana onde o cátion é liberado. o retorno do ionóforo é feito na forma protonada, e assim, efetua-se o transporte ionóforo-cátion e ionóforo-próton em direções opostas através da membrana celular (PRESSMAN, 1976) conforme o esquema abaixo:

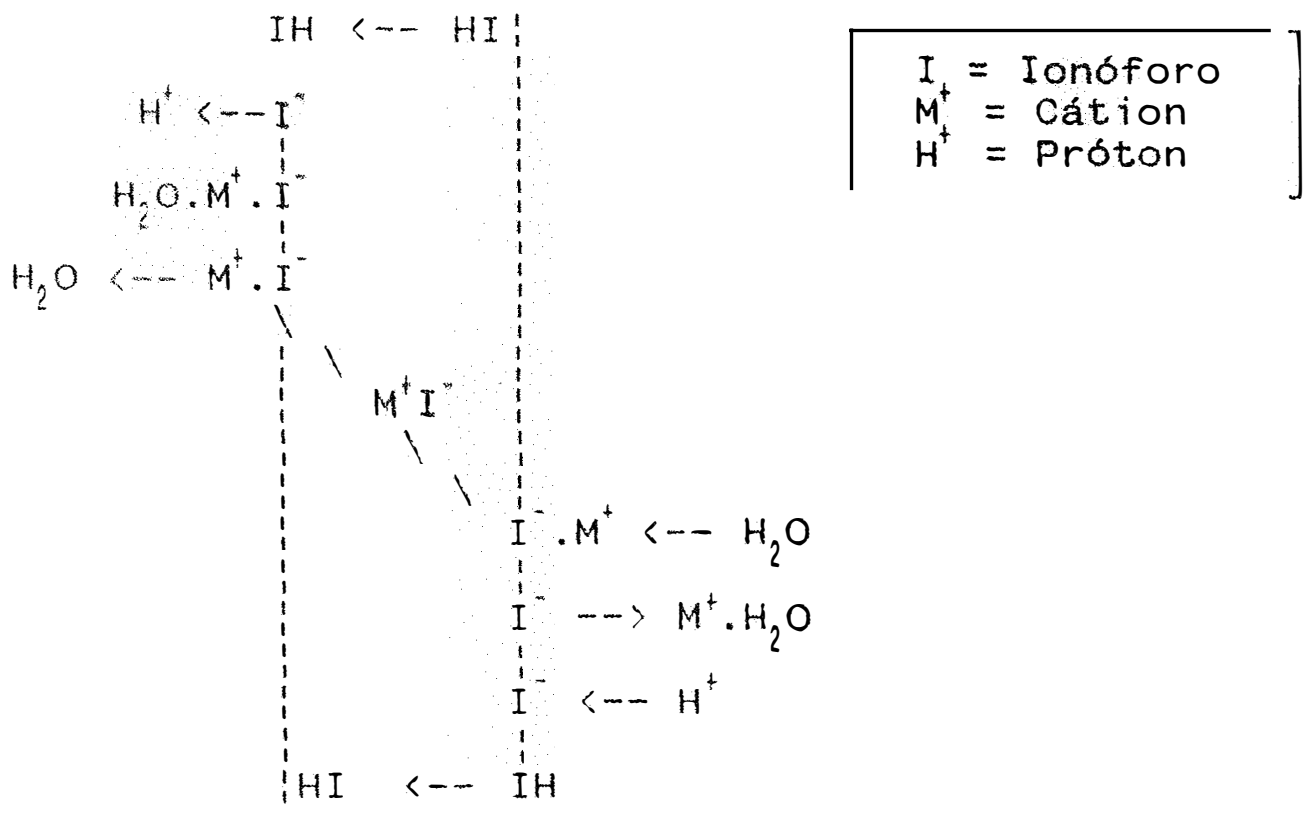

Pelo fato da monensina mediar obrigatoriamente o tranporte em direções opostas de um cátion e próton, ela é tida como um cátion/próton "antiporter" (transportador) (BERGEN e BATES, 1984). A lasalocida no entanto, pelo fato de poder mediar a troca $\mathrm{Ca}^{2+} / 2 \mathrm{~K}^{+}$não é tida como um cátion/próton "antiporter" obrigatório (BERGEN \& BATES, 1984). 
A reação catalizada pelo ionóforo depende do gradiente de concentração de ions, da afinidade do ionóforo por diferentes cátions e do mecanismo específico pelo qual a translocação de ion ocorre (BERGEN \& BATES, 1984). Segundo PRESMAN (1976) a monensina tem maior afinidade por sódio do que por potássio, enquanto a lasalocida tem uma afinidade muito maior por potássio do que por sódio.

As bactérias ruminais obtém sua energia, ou seja, ATP, através de 2 mecanismos (HINKLE \& MCCARTY, 1980):

a) Fosforilação a nivel do substrato

b) Fosforilaçăo oxidativa: algumas bactérias, principalmente certas gram-negativas, possuem um sistema de transporte de elétrons que pode ser utilizado para produzir ATP.

A extrusão de prótons através das ATP-ases ligadas à membrana de bactérias que produzem ATP por fosforilação ao nivel do substrato, ou a extrusão de prótons através da cadeia transportadora de elétrons nas bactérias que possuem fosforilação exidativa, criam um gradiente quimico de $\mathrm{pH}(\Delta \mathrm{pH})$ e um gradiente elétrico $(\Delta \mathrm{Y})$. Estes 2 gradientes juntos estabelecem a "força motora de prótons" (FMP) (BERGEN \& BATES, 1984; RUSSELL \& STROBEL, 1989). A energia acumulada na "FMP" pode ser usada para produzir ATP (nas bactérias que possuem sistemas de transporte de elétrons), para a absorção de solutos pela célula e para 
motilidade (RUSSELL \& STROBEL, 1989).

A capacidade do ionóforo em transportar cátions e prótons através da membrana celular pode afetar o gradiente estabelecido entre o interior e o exterior da célu1a. A adição de monensina em cultura de streptococcus bovis inverteu o gradiente de $\mathrm{pH}$ estabelecido entre o interior da célula e o meio, resultando em decréscimo da "FMP". Como o gradiente elétrico não foi afetado pela monensina, qualquer influxo de cátions deve ter sido compensado por um efluxo de cátions ou influxo de ânios (RUSSELL, 1987). A redução do nivel de ATP celular devido à tentativa da célula em restabelecer $\circ \Delta \mathrm{pH}$ pode ser 0 principal motivo da inibição de crescimento das bactérias sensiveis a ionoforo (RUSSELL, 1987; RUSSELL \& STROBEL, $1989)$

Existem 2 proposições básicas até o momento de como o ionóforo monensina modula a troca de cátions/prótons através da membrana de microrganismos ruminais:

\section{1) Proposiçao de BERGEN \& BATES (1984)}

Segundo estes autores a monensina mediaria um influxo celular do próton $\mathrm{H}^{+}$e um efluxo celular do cátion sódio. Desta maneira, o pH e a concentração de sódio no meio ruminal deveriam ter um papel importante no efeito do ionóforo. O aut pr propõe que a adição de bicarbonato de sódio ao meio ruminal poderia bloquear a ação da monensina devido 
à elevação do pH (redução do $\Delta p H$ ) e elevação da concentração de sodi no rúmen. Foi verificada em trabalhos experimentais uma redução no efeito da monensina devido à adição de bicarbonato de sódio, mas os autores consideraram que a lasalocida não seria afetada pela adição de bicarbonato de sódio.

2) Proposição de RUSSELL (1987)

Trabalhando com streptocóccus bovis, um microrganismo encontrado no rúmen, o autor verificou que a monensina mediou inicialmente a troca potássio/hidrogênio ao invés de sódio/hidrogênio, ou seja, a monensina ocasionou um influxo celular de hidrogênio $\left(H^{+}\right)$e efluxo de potássio $\left(K^{+}\right)$. Após o pH celular ter sido revertido, a monensina provocou um influxo celular de sódio $\left(\mathrm{Na}^{+}\right)$e um efluxo de $\mathrm{H}^{+}$. Os dados a seguir mostram o efeito de monensina sobre a "FMP" e a concentração de cátions em streptococcus bovis, de acordo com o autor:

\begin{tabular}{lcc}
\hline Paràmetros & Controle & Monensina \\
\hline pH do meio & 6,65 & 6,65 \\
pH celuiar & 7,08 & 6,20 \\
$\Delta p H(m V)$ & -26 & +28 \\
Ay (mV) & 77 & 71 \\
FMP (mV) & 103 & 43 \\
K meio (mM) & 9 & 9 \\
K celular (mM) & 613 & 134 \\
Na meio (mM) & 89 & 93 \\
Na celutar (mM) & 237 & 543 \\
\hline
\end{tabular}


Com base no trabalho, RUSSELL (1987) propôs que o nivel extracelular de potássio era mais importante que o nivel de sódio quanto ao efeito do ionóforo, ou seja, um nivel elevado de potássio no fluido ruminal poderia bloquear o efeito da monensina.

RUMPLER et a Tii (1986) testando monensina e lasalocida na presença e na ausência de dois tipos de cátions (controle; $2,5 \%$ de sódio; $2,5 \%$ de potássio na matéria seca da dieta) verificaram que a adição de sódio via cloreto de sódio melhorou a eficiência da monensina e tendeu a melhorar a eficiência da lasalocida em reduzir a produção de metano. A adição de potássio, via cloreto de potássio, tendeu a aumentar a produção de metano na presença de lasalocida. DAWSON \& BOLING (1987), testando monensina e lasalocida com niveis baixo, médio e alto de potássio, verificaram que o efeito dos ionóforos foi prejudicado pelo nivel alto de potássio. Funk et alii (1986) observaram que níveis altos de potássio na dieta, apesar de não afetarem o desempenho de cordelros suplementados com lasalocida, anularam o efeito do ionoforo em favorecer a produção de ácido propiónico.

SPEARS \& HARVEY (1987) testando o efeito de niveis de sódio e potássio sobre o desempenho de animais suplementades cm lasalocida, verificaram que o ionóforo foi eficiente em melhorar a conversão alimentar de novilhos em terminação, exceto quando a dieta tinha nivel alto de potássio e baixo de sódio. 
RUSSELL \& STROBEL (1989) revisando trabaithos de pesquisa, ralataram que à medida que o nível de potássio na dieta aumentou, o efeito da lasalocida e o da monensina foi reduzido.

RUSSELL (1987) contestou o esquema proposto por BERGEN \& BATES (1984), afirmando que:

a) A proposta dos autores mencionados năo foi baseada em determinações experimentais, mas sim, em extrapolaçốes de dados obtidos com mitocôndria e Escherichia coli, não utilizando microrganismos rumina is.

b) A proposta apresentada considerou a maior afinidade da monensina por sódio em relação ao potássio, não levando em conta que a concentração de potássio no interior da célula, que é muito maior que a de sódio, e que o gradiente de potássio através da membrana também é superior ao gradiente de sódio.

\section{STAPLES \& LOUGH (1989) revisando diversos}

trabalhos sobre a utilização de agentes tamponantes em dietas de vacas de leite, verificaram que bicarbonato de sódio foi eficiente em manter $\mathrm{o} p \mathrm{pH}$ ruminal dentro de niveis mais favoráveis à atuação das bactérias celulolíticas. Entretanto; os autores ressaltaram que um tamponante verdadeiro, como o bicarbonato de sódio, deve agir evitando a queda do $\mathrm{pH}$ 
ruminal sem ocasionar a elevação deste. A análise dos dados de STAPLES e LOUGH (1989) permite observar que, mesmo quando o bicarbonato de sódio foi utilizado em níveis bem acima do recomendado, a elevação do $\mathrm{pH}$ ruminal jamais ultrapassou 0,21 unidades e o pH ruminal médio de vacas recebendo até 418 gramas por dia do agente tamponante foi 6,04 contra 5,91 das vacas controle.

Com base nos dados compilados por STAPLES \& LOUGH (1989), parece ser reduzida a possibilidade do bicarbonato de sódio elevar o pH ruminal a níveis próximos do $\mathrm{pH}$ intracelular, bloqueando o infiuxo de prótons na célula microbiana mediado pelo ionóforo, como propuseram BERGEN \& BATES ( 1984$)$.

A resistência de diversos microrganismos ruminatis grammegativos aos ionoforos, segundo BERGEN \& BATES (1984), parece estar relacionada à ocorrência de fosforilação oxidativa nestas bactérias. Um sistema de transporte de elétrons e a presença da enzima fumarato redutase, permitiriam a estas bactérias, manterem a sua reserva energética devido à uma maior produção de ATP quando comparadas à bactérias gram-positivas, que só produzem ATP através da fosforilação ao nível do substrato.

RUSSELL \& STROBEL (1989), sem discordarem das vantagens advindas la ocorrência da fosforilação oxidativa em diversas bactérias gram-negativas, acreditam que a maior resistência destas bactérias aos ionoforos está mais 
fortemente correlacionada a presença de uma membrana externa, que funcionaria como uma barreira fisica à penetração dos ionoforos na célula. Esta membrana estaria ausente em diversas bactérias e outros microrganismos como fungos e protozoários sensiveis aos ionóforos.

ATguns estudos têm sido conduzidos com a finalidade de avaliar as vantagens de um sistema de rotaça de ionóforos $v$ isando reduzir a resistência de certas bactérias ou aumentar o efeito positivo dos ionóforos sobre o desempenho animal (RUSSELL \& STROBEL, 1989). A rotação de monensina, lasalocida e tilosina, pode favorecer o ganho de peso e a conversão alimentar em bovinos (BRANINE et ali i, $1989)$.

2.3.3. Alterações no rúmen e ação sobre utilizaçăo de energia e metabolismo proteico.

O efeito mais marcante do ionóforo sobre a fermentação ruminal é a ałteração nas proporções de ácido acético e ácido propiônico. De modo geral ocorre elevação na proporção molar de ácido propiônico e redução de ácido acético, resultando em menor relação ácido acético/ácido propionico, mantendo inalterada a produção total de AGV (BERGEN \& BATES, 1984; SCHELLING, 1984; RUSSELL \& STROBEL, 1989).

Acredita-se que a manipulação da fermentação 
ruminal visando favorecer a produção de ácido propiônico resulte em ganho energético para o animal, em função de diversos fatores, tais como:

a) Maior eficiência da fermentação da hexose a ácido propiônico (109\%) em relação a ácido acético (62\%) (CHALUPA, 1977 ).

b) O conceito de utilização mais eficiente de ácido propiônico em relação a ácido acético pelos tecidos, proposto (SCHELLING, 1984) e que tem sido questionado (BERGEN \& BATES, 1984).

c) A maior flexibilidade do ácido propionico como fonte energética, já que este pode ser utilizado tanto para a oxidaça no ciclo de krebs como para a gluconeogênese (SCHELLING, 1984).

BERGEN \& BATES (1984), analisando trabalhos de pesquisa relataram que hòve um acréscimo de $20 \%$ na energia metabelizável disponivel ao ruminante recebendo monensina, enquanto DELFINO et alii (1988), avaliando o desempenho e a partição de energia em bovinos suplementados com lasalocida, obtiveram um aumento de $7 \%$ na energia metabolizável da dieta, levando os autores a concluir que este parece ser o principal meio pelo qual lasalocida melhora a conversão alimentar.

A redução na produção de metano durante o processo fermentativo no rúmen, é outro aspecto que pode aumentar a densidade energética de dietas suplementadas com 
ionofotos (fumplep et alit, 1986). Reduçôes de 4 a $31 \%$ da produção de metano, devido ao uso de monensina foram relatados por SCHELLING (1984) em sua revisão sobre o assunto. A reduça na produção de metano não é consequencia de um efeito direto do ionóforo sobre as bactérias metanogênicas, mas sim, função de uma menor disponibilidade de hidrogênio para estas bactérias, devido à inibição de bactérias que o produzem (Ruminócoccus albus), e predomínio de bactérias que utilizam hidrogênio para a produção de ácido succinico (Bacteroides succinogenes e Bacteroides ruminicola), e para a produção de ácido propionico (Selenomonas ruminantium) (CHALUPA, 1980; SCHELLING, 1984). RUMPLER et alii (1986), observaram maior eficiência da monensina em inibir a produção de metano quando comparada à lasalocida enquanto DELFINO et ali (1988) não verificaram efeito da lasalocida na produção de metano.

A energia perdida como metano normalmente representa 7 a $10 \%$ da energia bruta da dieta, dessa maneira, considerando reduções máximas de $30 \%$ na produção de metano na presença de ionóforos, o aumento na energia liquida da dieta não deve ser superior a 3 a $5 \%$ segundo SCHELLING (1984) e DELFINO et alii (1988). SCHELLING (1984), afirmou que a reducão da produção de metano resulta em pequena melhoria da produção anima .

Segundo STROBEL et alii (1989), a maior produção de ácido propiônico e a redução na produção de 
metano não explicam metade dos benefícios derivados dos ionóforos, havendo portanto, outros fatores importantes, determinando o efeito positivo destes compostos na produção an imat.

Diversos autores af irmam que a monens ina reduz a degradação ruminal de proteina, resultando em menor nível de amônia ruminal e maior escape de proteina da dieta para o abomaso, justificando a suposição de que um dos modos de ação dos ionóforos em ruminantes é através de uma utilizacão mais eficiente da proteina, ou seja, o ionóforo economiza proteina (CHALUPA, 1980; BERGEN \& BATES, 1984; SCHELLING, 1984; GOODRICH et alii, 1984; RUSSELL \& STROBEL, 1989). BERGEN \& BATES (1984) relataram que a monensina aumentou o escape ruminal de proteina em 22 a 55\%, enquanto GOODRICH et alii (1984) anaitisando seis experimentos com novithos de corte, concluiram que monensina reduziu a necessidade de proteína da dieta para ganho de $1,0 \mathrm{~kg} /$ cabeça/dia de $11,6 \%$ para $11,2 \%$, suportando a teoria de que monens ina tem efeito de poupar proteina. Reduzir a degradaçăo ruminal da proteina da dieta, maximizar a produção de proteina microbiana a partir do nitrogênio não protéico e suplementar aminoácidos resistentes à degradaçăo ruminal, podem resultar em melhor desempenho de animais de alto potencial que estavam sofrendo alguma limitação, como também, em economia de proteina para aqueles animais que já estavam adequadamente supridos (CHALUPA, $1977)$ 
A resistência à monesina de bactérias com elevada capacidade de degradar proteínas e aminoácidos (Bacteroides ruminicola, Megasphaera elsdenit e selenomonas ruminantium), torna dificil explicar o efeito do ionóforo, reduzindo a degradação de proteína no rúmen. Porém, a descoberta de um peptostreptococcus ruminal sensivel à monensina e com um potencial de produzir amônia vinte vezes maior que o dos microrganismos anteriormente citados, pode ser uma das explicações para este fato, de acordo com RUSSELL \& STROBEL (1989).

SCHELLING (1984) afirmou que apesar do pequeno número de trabalhos sobre o assunto, normalmente a monensina reduz a taxa de diluição ruminal. Esta redução pode levar à uma maior exigência de manutenção dos microrganismos, reduzindo a produção de proteina microbiana no rúmen (HESPELL \& BRYANT, 1979). A menor eficiência de sintese de proteina microbiana na presença de monensina é discutida por BERGEN \& BATES (1984) enquanto RUSSELL \& STROBEL (1989) retatando trabalhos com culturas adaptadas à monensina, em sistema semicontínuo de longa duração, não observaram efeito negativo do ionóforo sobre a produção celular microbiana.

Assim como monensina, a lasalocida parece melhorar a eficiência de utił izaçăo da proteína da dieta visto que tem sido verificado aumento na digestibilidade do nitrogênio da dieta na presença deste ionoforo (PATERSON et alii, 1983; RICKE et alii, 1984; DELFINO et alii, 1988). 
Entretanto, a lasalocida parece não reduzir a degradação de proteina no rúmen como a nomensina, pois diversos trabalhos não têm verificado efeito da lasalocida sobre o nivel de amônia ruminal (RICKE et alii, 1984; SPEARS \& HARVEY, 1984; FUNK et a7ii, 1986; ANDERSEN \& HORN, 1987; DELFINO et a1ii, 1988). Ao que parece a lasalocida e a monensina não se comportam de forma semelhante no rúmen com relação à degradaçăo de proteína (RICKE et all i, 1984; FUNK et alii, $1986)$

STARNES et alii (1984) observaram redução de 66 e $28 \%$ na atividade da urease ruminal em presença de Tasalocida e monensina respectivamente, $o$ que pode ser interessante a fim de se proporcionar uma utilização mais eficiente da uréia no rúmen.

2.3.4. Efeite sobre o consumo, a digestibilidade e a taxa de passagem.

De modo geral, com dietas ricas em grãos, o uso de ionúforos resulta em redução de consumo (BERGEN \& BATES, 1984), da ordem de 5 a $6 \%$ segundo revisão feita por SCHELLING (1984), Quando a dieta é constituida basicamente por forragens, s ionóforos normalmente não deprimem o consumo (BERGEN \& BATES, 1984). A redução no consumo parece ser menos acentuada com a lasalocida do que com a monensina (THONNEY et alii, 1981). Entretanto, alguns trabaithos com 
dietas ricas em grãos não têm mostrado efeito depressivo da lasalocida sobre o consumo (FUNK et alii, 1986, SPEARS \& HARVEY, 1987; DELFINO et a1 i i, 1988).

Considerando o efeito depressivo do ionóforo sobre diversas bactérias celuloliticas (Ruminococcus albus, Ruminococcus flavefaciens e algumas linhagens de Butyrivibrio fibrisolvens), é de se esperar que a digestibilidade da fraçãofibrosa da dieta seja reduzida. Ensaios "in vitro" de curta duraçăo, têm confirmado esta suposição, o mesmo não ocorrendo com ensaios "in vivo" utilizando animais adaptados (SCHELLING, 1984; RUSSELL \& STROBEL, 1989). Um conjunto de fatores pode explicar este fato, tais como: a capacidade de Bacteroides succinogenes, um microrganismo com atividade celulolitica e menos sensivel a ionóforos, poder compensar a redução de Ruminococcus e Butyrivibrio. Bacteroides succinogeries tem um "lag time" bastante longo, assim, em experimentos "in vitro", de curta duraçăo, sua ação fica I imitada (RUSSELL \& STROBEL, 1989). O menor consumo, o maior tempo de permanència do alimento no rúmen (CHALUPA, 1980) e a menor produção de ácido 1ático, mantendo o pH em niveis favoráveis a ação das bactérias celuloliticas (STROBEL et alii, 1989), causados pelos ionoforos, podem favorecer a digestão de fibra.

FUNK et alii (1986), obtiveram maior digestibilidade da matéria seca no trato digestivo total, sendo que a digestibilidade do amido, nitrogênio e NoF não 
foram afetados por lasalocida. Houve tendéncia de redução na degradação ruminal da matéria orgânica e amido, sugerindo que a lasalocida pode alterar o local de digestão do rúmen para o intestino.

PATERSON et alii (1983), RICKE et alii (1984) e DELFINO et alii (1988), obtiveram maior digestibilidade do nitrogênio devido à lasalocida, porém, não observaram efeito sobre a digestibilidade da matéria seca e NDF. ANDERSEN \& HORN (1987) e STROBEL et alii (1989) também não observaram efeito da lasalocida sobre a digestibilidade da matéria seca. Segundo SCHELLING (1984), o aumento na digestibilidade devido à monensina parece ser pequeno e é afetado por diversos fatores, tais como, nivel de consumo, enchimento do rúmen e taxa de passagem ruminal.

Os mecanismos pelos quais os ionóforos parecem reduzir a taxa de passagem ruminal ainda não estão esclarecidos. A capacidade dos ionóforos em transportar ions pode alterar a concentraçăo osmótica do fluido ruminal (STARNES et alii, 1984). A redução na concentração de cá 1cio, magnésio e potássio, no fluido ruminal de animais recebendo racbes com 33 ppm de lasalocida ou monensina, foi considerada por STARNES ot alii (1984) como a principal causa da redução da ocmolalidade do fluido ruminal observada nesses animais. Segundo DESWYSEN \& ELLIS (1988), o maior tempo de retenção de particulas no rumen de animais suplementados com monensina, pode ser causado pelo efeito do ionóforo em reduzir o número 
e a força das contraçooses ruminais.

\title{
2.3.5. Outros efeitos dos ionóforos.
}

\begin{abstract}
A utilização de dietas ricas em concentrado, comuns em confinamentos de paises desenvolvidos, tem apresentado grande incidência de distúrbios metabólicos, principalmente acidose, resultando em queda de consumo, de ganho de peso e até mesmo a morte do animal (BRITTON \& STOCK,
\end{abstract} 1989; STROBEL et alii, 1989). Acidose é um distúrbio metabólico causado por rápida produção e absorção de ácidos organicos ruminais e de endotoxinas a partir de excessiva fermentação ruminal de carboidratos. Este conceito deixa claro que acidose não é consequência do acúmulo de ácido lático apenas, mas de todos os ácidos orgânicos produzidos no rúmen (BRITTON \& STOCK, 1989). Apesar do ácido lático não ser o único responsável pela acidose (BRITTON \& STOCK, 1989), ele é um ácido muito mais forte que os ácidos graxos voláteis produzidos no rúmen. Técnicas que reduzam a sua produção no rúmen podem auxiliar no controle da acidose (STROBEL et alii, $1989)$

o ácido lático é inicialmente produzido no rúmen devido à fermentação de carboidratos solúveis por Streptococcus bovis, ocasionando queda do $\mathrm{pH}$ e facilitando a proliferação de Lactobacilius, aumentando ainda mais a produção de ácido lático. Dessa maneira, a inibição de 
Streptococcus bovis é fundamental para se evitar o acúmulo de ácido lático no rúmen (NAGARAJA et alii, 1981). Diversos trabalhos têm mostrado que ionóforos inibem o crescimento de Streptococcus bovis, sem no entanto, afetar os microrganismos que fermentam o ácido lático (NAGARAJA et alii, 1981; NAGARAJA et alij, 1982, STROBEL et alii, 1989).

A suplementação com nomensina ou lasalocida mostrou-se eficiente em evitar acidose em animais recebendo dietas ricas em carboidratos solúveis, reduzindo o acúmulo de ácido lático e a queda do pH ruminal de acordo com NAGARAJA et alii (1981) e NAGARAJA et alii (1982). Estes autores também verificaram que a lasalocida foi mais eficiente que a monensina em prevenir acidose.

BERGEN \& BATES (1984) comentaram que o
potencial dos ionoforos em reduzir o timpanismo é,
provavelmente, devido à menor viscosidade do fluido ruminal, uma vez que microrganismos produtores de muco como os protozoários e streptococcus bovis, são inibidos pelos ionóforos.

Acredita-se que parte do efeito dos ionóforos no desempenho animal seja devido à alteraçóes no metabolismo intermediário, através de mecanismos que não envolvam alterações no metabolismo ruminal, já que 36 a $50 \%$ da monensina é absorvida por ruminantes de acordo com ARMSTRONG \& SPEARS (1988). Os mesmos autores relataram que a aplicação intravenosa de monensina em ruminantes reduziu a concentração 
sanguinea de potassio, magnésio e fósforo, aumentou a concentragia de glicose e ácidos graxos voláteis e alterou a secreção de insulina e LH, o que pode resultar em alterações na composicáo cerporal, e portanto, no ganho de peso e efietencia al imentar. Estes resultados reforçaram a suposição de que os ionóforos podem agir sobre o metabolismo dos ruminantes independente de alterações no rúmen. As observaçôs experimentais revelaram que a lasalocida não afetou as concentrações de minerais, hormonios e outros metabólitos no sangue. De acordo com os autores, este fato pode estar relacionado à diferenças na habilidade da monensina e lasalocida de alterarem os niveis intracelulares de sódio e cálcio.

Alterações nos niveis de metabólitos intermediários do metabolismo de carboidratos no fígado, sugerem alterações no metabolismo hepático de carboidratos favorecendo a gluconeogênese em animais recebendo monensina e lasalocida (BENZ et alii, 1989). Elevação no nível de glucose sanguinea em animais recebende lasalocida foi observada por THONNEY et a 1 i i (1981) e por SPEARS \& HARVEY (1984), enquanto outros pesquisadores verificaram que as concentraçães de minerais no sangue foram a1teradas por lasalocida (SPEARS \& HARVEY, 1984; STARNES et alii, 1984; CHIRASE et alii; 1988; STABEL et alii, 1989).

Segundo ARMSTRONG \& SPEARS (1988), os dados existentes não permitiam conclusões definitivas, sendo 
necessário maior número de trabalhos de pesquisa para se caracterizar a relevância do efeito dos ionóforos sobre o metabolismo intermediário independente do efeito no rúmen.

\subsubsection{Desempenho anima 1}

O efeito dos diferentes ionóforos parece ser semelhante em termos de desempenho animal. Em dietas ricas em grãos, os ionóforos normalmente reduzem o consumo sem afetar o ganho de peso, melhorando a eficiência alimentar. En dietas ricas em forragens os ionóforos aumentam o ganho de peso sem afetar o consumo, melhorando assim a eficiência alimentar (BERGEN \& BATES, 1984; GOOORICH et alii, 1984).

Os dados a seguir resumem os efeitos dos ionóforos sobre o desempenho de bovinos alimentados com dietas ricas em grãos.

\begin{tabular}{lcc}
\hline \multirow{2}{*}{ Ionoforo } & \multicolumn{2}{c}{ Ganho de Peso } \\
\cline { 2 - 3 } Monensina & $\begin{array}{c}\text { Conversão Alimentar } \\
\text { Controle }\end{array}$ \\
\hline Lasalocida & $99-110$ & $88-95$ \\
Narasina & $99-107$ & $90-96$ \\
Salinomicina & $87-100$ & $84-90$ \\
\hline
\end{tabular}

Fonte: BERGEN \& BRTES 11984 
Os efeitos de monensina sobre o desempenho de bovinos recebendo dietas com diferentes concentrações de energia são mostrados a seguir:

\begin{tabular}{lcccc}
\hline & & \multicolumn{2}{c}{ Desempenho } & (\% do Controle) \\
\cline { 3 - 5 } Dieta & $\begin{array}{c}\text { No de } \\
\text { Ensaios }\end{array}$ & Consumo Ganho & $\begin{array}{c}\text { Conversăo } \\
\text { de Pes }\end{array}$ & Alimentar \\
\hline Confinament. & 19 & 94 & 102 & 92 \\
Pastagem & 12 & -- & 117 & -- \\
Forragem Verie Picada & 3 & 98 & 123 & 85 \\
\hline
\end{tabular}

Fonte: CHALUPA (1971)

o efeito de lasalocida e monensina sobre o desempentio de bovinos confinados está sumarizado nos dados que se seguem:

\begin{tabular}{lccccc}
\hline & \multicolumn{4}{c}{$\%$ do Controle } \\
\cline { 2 - 4 } Medidas & 98 & 97 & 95 & & 102 \\
\cline { 2 - 4 } & 11 & 22 & 33 & & 33 \\
\hline Consulocida $(p p m)$ & & Monensina (ppm) \\
Ganho & 104 & 106 & 105 & 108 \\
Conversão & 96 & 91 & 91 & 94 \\
\hline
\end{tabular}

Fonta: CHALUPA $(1980)$

Analisando 228 ensaios que envolveram 11.274 bovinos utitizando dietas ricas em grãos, GOODRICH et alii (1984) concluiram que monensina aumentou o ganho de peso em $1,6 \%$, reduziu o consumo em $6,4 \%$ melhorando a conversăo 
alimentar em 7,5\%. Um resumo dos dados pode ser visto abaixo:

\begin{tabular}{lccc}
\hline Medidas & Controle & Monensina & Alteração \% \\
\hline No cabeças & 5696 & 5578 & \\
Peso Vivo inicial (Kg) & 284 & 283 & \\
Peso Vivo Final (Kg) & 430 & 432 & \\
E.M. da Dieta (Mcal/Kg MS) & 2,98 & 2,98 & \\
Monensina (mg/cab/dia) & ---- & 246 & $+1,6$ \\
Ganho de Peso (Kg/dia) & 1,09 & 1,1 & $-6,4$ \\
Consumo (Kg/MS/dia) & 8,27 & 7,73 & $-7,5$ \\
Kg MS/Kg ganho de Peso Vivo & 8,09 & 7,43 & \\
\hline
\end{tabular}

Fonte: Goopich et alij (1984)

SPEARS \& HARVEY (1987) e DELFIN et alii (1988), utilizando dietas com 85 e 90\% de concentrado na matéria seca, verificaram efeito positivo da lasalocida sobre a conversão alimentar de novithos enquanto THONNEY et alii (1981), trabalhando com dietas à base de cubos de alfafa e SPEARS \& HARVEY (1984) e ANDERSEN \& HORN (1987) trabalhando com bovinos em regime de pasto, verificaram maior ganho de peso com animais recebendo lasalocida.

SPROTT et ali $i$ (1988) revisando os trabalhos sobre o efeito dos ionóforos em vacas de cria e novithas para reposiçăo, recebendo dietas a base de forragens, verificaram efeito positivo destes agentes sobre o ganho de peso, conversão alimentar, intervalo do parto ao primeiro cio, reduçãona liade à puberdade e nenhum efeito prejudicial sobre a fertilidade em machos e fêmeas. A produção de leite na maioria dos trabalhos não foi prejudicada, podendo até ser aumentada. 


\section{MATERIATS E METODOS}

3.1. Himóteses de trabalho

Na presente trabalho, foram propostas quatro

dietas, com a finalidade de se avaliar o efeito do bicarbonato de sódio, da lasalocida e de cana-de-açúcar picada como fonte de fibra integra, em dietas à base de bagaço de cana-de-ạ̧úcar tratado sob pressão de vapor (BTPV) para bovinos confinados.

o uso conjunto do bicarbonato de sódio e lasalocida, em dietas à base de BTPV, pode apresentar resultados interessantes, tanto pelo efeito isolado de cada composto a nivel de rúmen e metabolismo intermediário, como também, pelo possivel efeito benéfico de um nivel mais elevado de sódio na dieta, acentuando a ação do ionóforo.

- BTPV apresenta elevada acidez, baixo estimulo a ruminação, e consenquente baixa produçâo de saliva pelo ruminante, podendo resultar em um ambiente ruminal desfavoráver à degradação da sua fração fibrosa (CASTRO, 1989), e propicio à distúrbios metabólicos, como acidose (STROBEL et alii 1989). O uso de agentes tamponantes apresenta maior potencial de resposta quando o volumoso 
utilizado é caracteristicamente ácido (STAPLES \& LOUGH, 1989). Assim sendo, as dietas à base de BTPV parecem ter todas as características favoráveis à uma resposta positiva à adição de agentes tamponantes. Os dados de LANNA \& BOIN (1988) confirmam esta proposta, porém NUSSIO et alii (1990) não verificaram resposta positiva à adiçăo de bicarbonato de sódio em dietas à base de BTPV.

O BTPV apresenta elevada taxa de passagem ruminal (CASTRO, 1989), e acredita-se também, que este alimento reduz a digestibilidade da proteina (PATE, 1982; CASTRO, 1989). O uSo de lasalocida poderia melhorar a eficiencia de utilização do BTPV através de um processe fermentativo mais eficiente no rúmen, devido à maior produção de ácido propionico e redução na produção de metano (RUSSELL, 1987). A lasalocida parece aumentar a digestibilidade da proteina da dieta (PATERSON et alii, 1983; RICKE et alii, 1984; DELFINO et alii, 1988) e também reduz a taxa de passagem ruminal (SCHELLING, 1984), o que poderia melhorar o aproveitamento da fração fibrosa do BTPV. Entretanto, CASTRO (1989), afirmou que seria mais interessante aumentar a taxa de degradaço da fraça fibrosa do BTPV em vez de aumentar o tempo de retenção deste no rúmen. A lasalocida também poderia auxiliar na manutenção de um pH ruminal favorável à deg adscâ da fipra, devido à inibiça de microrganismos - rodutores de ácid lático (NAGARAJA et alii, 1981; NAGARAJA et alii, 1982; STROBEL et alii, 1989). 
Admite-se que a adição de uma fonte de fibra integra em dietas à base de BTPV, poderia estimular a ruminação, promovendo uma maior produção de saliva, melhorando o ambiente ruminal (LANNA \& BOIN, 1988). A canade-acucar tem sido utilizada em confinamentos comerciais em dietas a base de BTPV, como fonte de fibra. Entretanto, a sua utilização considerada problemática, por aumentar o trabatho de preparo e distribuição de alimento. A validade de uso de cana picada tem sido questionada mas não pesquisada.

\subsection{Local e animais}

O trabaino de campo foi conduzido nas instalações do Departamento de Zootecnia da ESALQ-USP em Piracicaba - SP, de 24 de fevereiro a 26 de maio de 1988. Foram utilizadas 20 baias com piso de concreto, cochos cobertos e área de $28 \mathrm{~m}^{2}$ por baia ou $14 \mathrm{~m}^{2}$ por animal.

Utilizou-se 40 animais da raça nelore, irmãos por parte de pai (com exceção de apenas 2 animais) sendo 24 machos e 16 fêmeas com idade média de 18,9 meses e peso vivo médio de $329 \mathrm{~kg}$ no início do período experimental. Durante o ano de 1987, logo após a desmama, os animais foram mantidos em confinamento experimental, por um período de 107 dias entre juitho e outubro. Após este perfodo, os animais foram mantidos em regime de pasto até 24 de fevereiro de 1988 , quando teve inicio o periodo ré-experimental deste trabaiho. 


\subsection{Tratamentos}

O trabalho experimental foi conduzido através do uso de quatro dietas.

$A-$ Bagaço tratado sob pressåo de vapor (BTPV) + concentrado + cana picada

$B \rightarrow$ BTPV + concentrado + cana picada + lasalocida

C $\rightarrow$ BTPV + concentrado + lasalocida + bicarbonato de sódio

D $\rightarrow$ BTPV + concentrado + cana picada + lasalocida + bicarbonato de sódio.

O nivel de lasalocida na matéria seca das dietas $B, C$ e $D$ foi calculado para situar-se entre 20 a 30 ppm conforme os dados da 1 iteratura (CHALUPA, 1980; GOODRICH et alii, 1984), enquanto o nivel de bicarbonato de sódio na matéria seca das dietas $C$ e $D$ foi calculado para atingir 1,\% ( LANNA \& BOIN, 1988).

Tomando-se com base a matéria seca, a proporção concentrado:volumoso de 40:60, foi mantida nas 4 dietas, sendo as dietas formuladas para serem isoprotéicas e isonergéticas.

Foram formulados 3 concentrados à base de milho triturado, farelo de algodão (28\% de PB), uréia, calcario mistura mineral. A diferença entre estes concentrados foi a presença ou ausência de lasalocida e de 
bicarbonato de sódio. A tabela 1 mostra a formulação dos concentrados usados para formulação das dietas experimentais.

Tabela 1. Formulação dos concentrados usados no experimento.

\begin{tabular}{lccc}
\hline $\begin{array}{l}\text { Componentes } \\
(\% \text { da Matéria Seca) }\end{array}$ & $\begin{array}{c}\text { Concentrado } \\
(\mathrm{C} 1)\end{array}$ & $\begin{array}{c}\text { Concentrado } \\
(\mathrm{C} 2)\end{array}$ & $\begin{array}{c}\text { Concentrado } \\
(\mathrm{C3})\end{array}$ \\
\hline $\begin{array}{l}\text { Milho Triturado } \\
\text { Farelode Algodão }\end{array}$ & 45,6 & 45,6 & 44,4 \\
Uréta & 45,6 & 45,6 & 44,4 \\
Calcário & 3,8 & 3,8 & 3,7 \\
Suplemento Mineral* & 2,5 & 2,5 & 2,5 \\
Cloreto de Potassio & 1,25 & 1,25 & 1,25 \\
Bicarbonato de sódio & - & 1,25 & 1,25 \\
Taurotec* & - & - & 2,5 \\
\hline
\end{tabular}

\footnotetext{
* Taurotec - Produto comerciallzado cela Roche do Brasil com $15 \%$ de lasalocida sódica.

Sud lemento mineral: Sulfato de amonio: 41,56 iodato de potássio: $0,017 \%$ Cloreto de sódio: $41,5 \%$ Sulfato de cobalto: $0,014 \%$ Oxido de magnésio: $13,8 \%$ Selenito de sódio : $0,011 \%$ Sulfato de zinco: $0,34 \%$ Vitamina ADE : $2,8 \%$ Sulfato de cobre: $0,083 \%$

* Calcário dolomitico com PRNT a 00 o (Hinercal)
}

A tabela 2 apresenta a proporção estimada dos ingredientes das 4 dietas empregadas no experimento, expressa em base de matéria seca. 
Tabela 2. Proporção dos ingredientes nas dietas experimentais.

\begin{tabular}{lrrrc}
\hline $\begin{array}{l}\text { Ingredientes } \\
(\% \text { da MS })\end{array}$ & A & B & C & D \\
\hline BTPV \% & 50 & 50 & 60 & 50 \\
Concentrado \% & 40 & - & - & - \\
C1 & - & 40 & - & - \\
C2 & 10 & 10 & - & 40 \\
C3 & & & - & 10 \\
Cana Picala \% & & & & \\
\hline
\end{tabular}

A tabela 3 apresenta a composição estimada dos al imentos empregados na formulação das dietas experimentais, expressa em base de matéria seca.

Tabela 3. Composição estimada dos alimentos utilizados, expressa em base de matéria seca.

\begin{tabular}{|c|c|c|c|c|c|}
\hline \multirow{2}{*}{$\begin{array}{l}\text { Composição na } \\
\text { matéria seca }\end{array}$} & \multirow[b]{2}{*}{ BTPV } & \multirow[b]{2}{*}{ cana-de-açúcar } & \multicolumn{3}{|c|}{ Concentrado } \\
\hline & & & $c 1$ & $\mathrm{C} 2$ & C3 \\
\hline MS (\% na MO) & 39,90 & 22,90 & 90,40 & 90,20 & 90,30 \\
\hline $\mathrm{PB}(\%)$ & 1,40 & 2,32 & 31,20 & 32,10 & 29,80 \\
\hline ENN $(\%)$ & 51,80 & 65,90 & 50,00 & 49,00 & 51,10 \\
\hline$E E \quad(\%)$ & 0,50 & 0,57 & 2,10 & 2,00 & 2,15 \\
\hline$M M(\%)$ & 4,20 & 4,80 & 7,00 & 6,20 & 7,10 \\
\hline $\mathrm{FB} \quad(\%)$ & 42,10 & 26,40 & 9,80 & 10,80 & 9,90 \\
\hline NDF $(\%)$ & 65,20 & 53,50 & ---- & ---- & $-\cdots-$ \\
\hline $\operatorname{ADF}(\%)$ & 64,70 & 36,50 & 14,00 & 16,00 & 16,90 \\
\hline DVIV (\%) & 64,00 & ----- & $-\cdots-$ & ----- & $-\ldots-n$ \\
\hline NDT $(\%)^{*}$ & 47,80 & 62,80 & 75,52 & 74,72 & 75,28 \\
\hline $\mathrm{Ca}(\%)$ & $\ldots-\cdots$ & ----- & 0,67 & 0,87 & 0,90 \\
\hline$P(\%)$ & $-\cdots--$ & ----- & 0,32 & 0,36 & 0,35 \\
\hline Lasalocida $(\mathrm{ppm})^{* *}$ & $--\cdots$ & ----- & --- & 61,60 & 66,10 \\
\hline $\mathrm{NaHCO}_{3}$ & - & - & - & - & $\therefore$ \\
\hline
\end{tabular}

"Estimado pela aquapto de reşrassà̃o de KeARL, compilada por Boin (1988).

"Ourante 040 sub-periodo exparimental o concentrado 02 apresentou 93 ppo de lasalocida sódica e o C3 3presentou 51 ppm. 
Através de análises laboratoriais, fei

possivel estimar a composiçăo média das quatro dietas empregadas no experimento. A tabela 4 apresenta a composição estimada das 4 dietas empregadas no experimento expressa em base de matéria seca.

Tabela 4. Composição estimada das dietas experimentais expressa em base de matéria seca.

\begin{tabular}{|c|c|c|c|c|}
\hline \multirow{2}{*}{$\begin{array}{c}\text { Composição na } \\
\text { matéria seca }\end{array}$} & \multicolumn{4}{|c|}{ Dietas } \\
\hline & A & $B$ & $c$ & $D$ \\
\hline MS (\% na Mo) & 46,90 & 46,90 & 51,40 & 46,90 \\
\hline PB $(\%)$ & 13,41 & 13,77 & 12,76 & 12,85 \\
\hline ENN (\%) & 52,50 & 52,10 & 51,52 & 52,94 \\
\hline$E E(\not)$ & 1,15 & 1,11 & 1,16 & 1,17 \\
\hline $\operatorname{MM}(\%)$ & 5,38 & 5,06 & 5,36 & 5,42 \\
\hline$F B(\%)$ & 27,56 & 27,96 & 29,22 & 27,60 \\
\hline ADF ( & 41,60 & 42,40 & 45,58 & 42,76 \\
\hline NOT ( & 60,39 & 60,00 & 58,79 & 60,29 \\
\hline $\mathrm{Ca}(\% /)^{*}$ & 0,27 & 0,35 & 0,36 & e, 36 \\
\hline$P(\%)^{*}$ & 0,13 & 0,14 & 0,14 & $0,1,4$ \\
\hline Lasa1ocida (ppm) & $-\cdots-\cdots$ & 24,64 & 26,44 & 26,44 \\
\hline
\end{tabular}

" haliso realizadzala hoche

Durante 0 40 sub-perfodo a dieta $B$ apresentou 37,2 ppm de lasalocida e as dietas $C$ a $D$ apresentaram 20,4 pom.

O BTPV utilizado foi produzido na Destilaria Alcidia (Teodoro Sampaio, SP), tendo sido tratado a uma pressão de $17 \mathrm{kgf} / \mathrm{cm}^{2}$ durante 5 minutos, de acordo com a preposta de BURGI (1985), e armazenado em silo tipo trincheira por um periodo de aproximadamente 6 meses. Removido para a E.S.A.L.Q., o material foi colocado sobre o solo, compactado com trator e coberto com lona plástica. 


\subsection{Conduça do experimento}

\subsubsection{Periodo pré-experimental}

o periodo pré-experimental teve inicio no dia 24 de fevereiro de 1988, e teve a duração de 25 dias. Os animais foram vacinados contra febre aftosa e vermifugados no primeiro dia deste periodo, utilizando o produto comercial Ripercol injetável, (cujo principio ativo é o levamisole), na dosagem de $1 \mathrm{mI}$ para cada $20 \mathrm{~kg}$ de peso vivo.

Durante os primeiros dez dias de confinamento, os animais receberam uma dieta à base de BTPV à vontade, $2 \mathrm{~kg}$ de concentrado com $25 \%$ de proteína bruta, $2 \mathrm{~kg}$ de feno de coast-cross por cabeça/dia e o suplemento mineral empregado pelo Departamento de zootecnia para o rebanho de corte à vontade. Nos quinze dias subsequentes, até o inicio do periodo experimental os animais receberam também à vontale, uma dieta básica com 50\% de BTPV, $10 \%$ de cana picada e $40 \%$ concentrado (base de matéria seca), sendo feita a adaptação à uréia.

\subsubsection{Periodo experimental}

Este periodo teve duraçăo de 66 dias, sendo composto de 4 sub-periodos de 14 dias e um sub-periodo final de 10 dias, que teve que ser encurtado para permitir a retirada dos animais do Departamento de Zootecnia. Acreditou- 
se na ocasião que no final do experimento, 10 dias seriam suficientes para avaliar o ganho de peso do sub-periedo.

Tanto a lasalocida como o bicarbonato de sódio foram introduzidos nas dietas no primeiro dia deste periodo, sem adaptação prévia, devido ao atraso no recebimento do ionóforo. Sabia-se que este fato reconhecidamente interferiria com o desempenho dos animais devido à falta de adaptação (GOODRICH et alii, 1984; SCHELLING, 1984).

A alimentação foi fornecida apenas uma vez ao dia, as 18 hs. Os volumosos e os concentrados respectivos eram pesados e então homogeneizados nos cochos com o auxilio de forcas, gadanhos e enxadas.

No inicio os animais foram pesados após jejum de 18 horas de alimento e água. Procedeumse a uma nova vermifigaçã 44 dias após a primeira aplicação, utilizando o produto comercial tetramisol injetavel (cujo princípio ativo é o tetramisole), na dosagem de $1 \mathrm{ml}$ para cada $15 \mathrm{~kg}$ de peso viro.

Durante todo o experimento os animais tinham a disposiça, à vontade, em cochos especiais, a mistura mineral utilizada pelo Departamento de Zootecnia para o rebanho de corte.

3.4.3. Coleta de dados

As pesagens dos animais foram feitas a cada 14 
dias com exceção do 50 sub-período que teve duração de 10 dias. Os animais foram mantidos em jejum de água e alimento por 18 a 20 horas antes de cada pesagem. A balança era sempre aferida antes do inicio da coleta de dados.

Tanto o BTPV como a cana-de-açúcar eram amostrados semanalmente para determinação da matéria seca, a fim de que as proporções dos ingredientes da dieta fossem aferidas. Estas amostras também foram utilizadas para a análise bromatológica completa, realizada pelo Laboratório de Bromatologia do Departamento de Zootecnia.

$$
\text { Para a avaliação de consumo, o alimento }
$$

fornecido era pesado diariamente, e as sobras retiradas e também pesadas diariamente. Amostras compostas eram preparadas para a determinaçăo da matéria seca, semanalmente. Procurou-se manter um nível de sobra sempre inferior a $10 \%$ do consumido.

Os concentrados foram preparados em batidas de $250 \mathrm{~kg}$, coletando-se uma amostra por batida para a análise bromatológica.

As determinações de matéria seca em estufa, extrato etéreo, fibra bruta, extrativo não nitrogenado e cinzas foram efetuadas segundo os métodos da A.O.A.C. (1965). As determinações de NDF e ADF foram efetuadas segundo GOERING \& VAN SOEST (1970). A análise de digestibilidade verdadeira "in vitro" do BTPV foi efetuada pelo método TILLEY e TERRY (1963), substituindo o segundo estágio de digestão por 
extração com solução de detergente neutro segundo GOERING \& VAN SOEST (1970). ESSa determinação foi usada para aferir o efeito do tratamento sob pressão de vapor e tem sido usada rotineiramente pelo Departamento de Zootecnia com essa final idade.

\subsection{Delineamento experimental}

o delineamento estatistico utilizado foi o fatorial em blocos casualizados, constando de 3 blocos, 4 dietas, 2 sexos e 5 sub-periodos experimentais de avaliação de desempenho. Os blocos eram desbalanceados, sendo que os de no 1 e no 2 eram completos, ou seja, haviam 4 parcelas (baias) para machos e 4 para fêmeas, com dois animais em cada parcela. o bloco ne 3 continha apenas 4 parcelas experimentais referentes aos machos, pois não haviam fèmeas suficientes para completar o bloco. Haviam portanto, 20 parcelas experimentais (baias), com 2 animais cada uma, perfazendo um total de 40 animais. $0 s$ animais foram pesados e agrupades nos blocos, procurando se obter a maior uniformidade possivel dentro de cada bloco. Procedeu-se então ao sorteio dos tratamentos (dietas).

A análise estatística dos dados foi realizada através do procedimento "GLM" de análise de variância do programa estatistico "SAS (1988)".

As variáveis analisadas foram: consumo de 
matéria seca, ganho de peso e conversão alimentar, sendo a comparação entre médias realizada pelo teste "Média dos quadrados mmnímos" (LSM), adotando o nível de probabilidade igual ou inferior a $5 \%$ como estatisticamente significativo. A análise estatistica para ganho de peso individual foi efetuada por covariancia, sendo os dados ajustados ao peso vivo inicial dos animais.

o esquema de análise de variância utilizado foi o seguinte.

\begin{tabular}{lc}
\hline Causa da Variação & Graus de Liberdade \\
\hline Ploco & 2 \\
Sub-periodo (P) & 4 \\
Dieta D & 3 \\
Sexo (S) & 1 \\
D S & 3 \\
PXD & 12 \\
PXS & 4 \\
PXDXS & 12 \\
\hline Residuo & 53 \\
\hline Total & 94 \\
\hline
\end{tabular}

Durante o transcorrer do experimento houve a perda de 3 parcelas experimentais relacionadas a seguir:

a) No bloco 1 foi perdido o tratamento referente a dieta $D$ para fêmeas nos sub-períodos 4 e 5 .

b) No bloco 3 foi perdido o tratamento referente a dieta D para machos nos sub-períodos 4 e 5 .

c) No bloco 3 foi perdido o tratamento referente a dieta A para machos no sub-período 5 . 
A perda das parcelas foi devido ao fato de que alguns animais apresentaram problemas de saúde não caracterizados, que afetaram o comportamento e o consumo. Foram, por esse motivo, eliminados do confinamento. 


\section{RESULTADOS E DTSCUSSÃO}

\subsection{Consumo de matéria seca}

4.1.1. Nivel e comportamento de consumo

A tabela 5 mostra que a análise estatistica

realizada para avaliar o efeito das dietas util izadas no presente estudo sobre o consumo diário de matéria seca, indicou efeitos semelhantes quando a variável foi analisada em termos de $\mathrm{Kg}$ de MS/cabeça.dia, $\mathrm{Kg}$ MS em xPV ou g MS/Kg $p V^{\prime \prime}$, Assim sendo os resultados foram discutidos somente em função da estimativa que mostra de maneira mais precisa do ponto de vista biológico os efeitos das dietas sobre a ingestão de alimentos, ou seja, consumo em função do peso metabólico (A.R.C., 1984).

Tabela 5. Efeito das dietas sobre o consumo diário de MS estimado.

\begin{tabular}{|c|c|c|c|c|c|}
\hline \multirow{2}{*}{\multicolumn{2}{|c|}{ Variavel }} & \multicolumn{4}{|c|}{ Dietas } \\
\hline & & A & $B$ & $c$ & D \\
\hline & $\mathrm{MS} / \mathrm{Kg} P V^{0.15}$ & $135,53^{a}$ & $129,07^{b}$ & $130,02^{b}$ & $139,71^{6}$ \\
\hline & s & 1,17 & 1,21 & 1,14 & 1,27 \\
\hline Kc & ${ }^{g}$ MS/cabeça & $\begin{array}{r}11,52^{a} \\
0,11\end{array}$ & $\begin{array}{r}10,96^{b} \\
0,11\end{array}$ & $\begin{array}{l}11,11^{b} \\
0,10\end{array}$ & $0^{11,95^{\circ}} 0,12$ \\
\hline$K \varsigma$ & $\begin{array}{r}g \text { MS em } \% \text { PV } \\
\\
5\end{array}$ & $\begin{array}{l}3,09^{a} \\
0,03\end{array}$ & $\begin{array}{r}2,94^{b} \\
0,03\end{array}$ & $2,96^{b}$ & $2^{3,18^{c}} 0,03$ \\
\hline
\end{tabular}

$a: b, c$ - na mesma linha médias sequidas de letras diferentes diferen entre si $(P \leq 0,05)$. 
o nivel de consumo verificado neste experimento foi superior à média obtida em outros trabaihos que utilizaram dietas à base de bagaço tratado sob pressão de vapor (BTPV), e obtiveram valores entre 104 e $116 \mathrm{~g} \mathrm{MS} / \mathrm{Kg}$ PV 0.75 (LANNA \& BOIN, 1988; NUSSIO et alii, 1990). Vale ressaltar que o BTPV utilizado no presente ensaio permaneceu armazenado em silo trincheira durante aproximadamente 6 meses. Observações de campo têm levado à suposição de que o armazenamento do BTPV por um certo periodo antes do fornecimento aos animais, pode favorecer um consumo mais elevado de matéria seca. Este fato acentua a importância de se estudar o processo de conservação desse resíduo industrial.

O elevado consumo de matéria seca verificado em dietas à base de BTPV deve-se principalmente à alta taxa de passagem ruminal, conforme observaçóes realizadas por CASTRO (1989). O tratamento sob pressão de vapor reduz o tamanho das particulas de bagaço, aumentando a sua friabllidade e densidade, favorecendo assim uma rápida taxa de passagem ruminal (CASTRO, 1989).

E. fato conhecido que o BTPV é um alimento pobre em proteina e minerais e de médio valor energético (MATTOS, 1985). Entretanto, o elevado consumo verificado em diversos trabalhos de pesquisa (BURGI, 1985; LANNA \& BOIN, 1988; NUSSIO et alii, 1990), e em confinamentos comerciais (PLANO CONSULTORIA AGROPECUARIA, 1989), pode ser considerado 
como um fator altamente positivo para o uso desse alimento. O consumo superior a praticamente $130 \mathrm{~g}$ de matéria seca por $\mathrm{kg} \mathrm{PV}, 15$ verificado no presente experimento, possibilitou que os animais ingerissem quantidades de energia, proteina e minerais adequados para um bom desempenho, como pode ser visto na Tabela 6 , que mostra o consumo estimado médio de nutrientes, comparado com as exigências nutricionais dos bovinos.

A observação das estimativas apresentadas na tabela 6 mostra que o consumo de todos os nutrientes, com exceção do fósforo, foi suficiente para niveis de ganho de peso diários entre 1,2 e $1,4 \mathrm{~kg}$ para machos e superior a $1 \mathrm{~kg}$ para fêmeas. Deve-se ressaltar que, a aparente deficiência de fósforo, não afetou o consumo nem o ganho de peso dos bovinos confinados. Esse fato talvez possa ser explicado pela existência de mistura mineral completa à vontade no cocho durante todo o experimento, cujo consumo não foi medido.

O consumo de $\mathrm{PB}$ estimado para machos e fêmeas do experimento p de ser considerado elevado, quando comparado com os niveis propostos pelo NRC (1984). Entretanto, deve se considerar que dietas ricas em constituintes da parede celular podem ser melhor utilizadas pelos bovinos quando em presenga de niveis mais elevados de nitrogênio, capazes de elevar a quantidade de $\mathrm{NH}_{3}$ no fluido ruminal (TAMMINGA, 1979). Além desse aspecto, alimentos fibrosos apresentando elevada taxa de passagem ruminal, como o BTPV, poderiam ser 
utilizados mais eficientemente com um nivel mais elevado de proteina, capaz de favorecer uma maior taxa de degradação da frạ̧ão fibrosa no rúmen (FRANCISCO Jr. \& MACHADO, 1990). Pode-se também considerar que o efeito tamponante, principalmente da uréia, poderia ser benéfico em dietas à base de BTPV, já que as condições de pH no rúmen tendem a ser baixas, com o uso desse alimento (FRANCISCO Jr. \& MACHADO, 1990). Outro fator a ser considerado, é que os trabathos de PATE (1982) e CASTRO (1989) indicaram um efeito negativo do BTPV sobre a digestibilidade da proteina, e este fato poderia justificar a utilização de niveis de proteina bruta em dietas à base de BTPV acima das recomendações do NRC (1984).

A análise de variância levada a efeito para a variável consumo de matéria seca (Tabela 1 do apêndice) indicou efeitos significativos para sub-periodos e sexo, mas a interação não foi significativa. A tabela 7 mostra a análise do consumo de matéria seca nos diferentes subperíodos experimentais para machos e fêmeas, indicando que as fêmeas consumiram significativamente mais alimento que os machos. Essa mesma caracteristica foi observada por LANNA \& BOIN (1988) trabalhando com BTPV, e foi explicado pelos automes citados, como decorrente da diferença na composição do ganho de peso corporal entre os sexos. 
Tabela 6. Consumo diário de nutrientes por um bovino (macho) médio de $393 \mathrm{~kg}$, e por um bovino (fêmea) médio de $335 \mathrm{~kg}$ comparado com suas exigências nutricionais.

\begin{tabular}{|c|c|c|c|c|c|}
\hline \multirow[b]{2}{*}{ Nutrientes } & & \multirow{3}{*}{$\begin{array}{l}\text { Consumo } \\
\text { estimado }\end{array}$} & Exigências & para ganthos & s diários \\
\hline & & & \multicolumn{2}{|c|}{ Macho } & \\
\hline & & & $1,0 \mathrm{~kg}$ & $1,2 \mathrm{~kg}$ & $1.4 \mathrm{~kg}$ \\
\hline Ms/cabeca/dia & a $\mathrm{Kg}$ & 11,36 & 9,00 & 9,10 & 8,30 \\
\hline $\mathrm{Ms} / \mathrm{Kg} \mathrm{Pv}^{0.75}$ & 9 & 128.07 & 100,60 & 101,70 & 99,50 \\
\hline NDT $/ d i a^{2}$ & $\mathrm{Kg}$ & 6.80 & 6,04 & 6,44 & 6,81 \\
\hline $\mathrm{PB} / \mathrm{dia}$ & $\mathrm{Kg}$ & 1,50 & 0,88 & 0,93 & 0,97 \\
\hline $\mathrm{Ca} / \mathrm{dia}$ & $\mathrm{g}$ & 38,60 & 30,00 & 33,00 & 36,00 \\
\hline \multirow[t]{3}{*}{$P / d i a$} & $g$ & 16,00 & 19,00 & 20,00 & 21,00 \\
\hline & & \multicolumn{4}{|c|}{ Fêmea } \\
\hline & & & $0,6 \mathrm{~kg}$ & $0,8 \mathrm{Kg}$ & $1,0 \mathrm{~kg}$ \\
\hline MS/cabeça/dia & a $\mathrm{Kg}$ & 11,40 & 7,30 & 7,40 & 7,20 \\
\hline$M S / K g \quad P V^{0,75}$ & $g$ & 139,09 & 90,21 & 91,45 & 88,98 \\
\hline NDT $/ \mathrm{dia}$ & $\mathrm{Kg}$ & 6,82 & 4,70 & 5,20 & 5,60 \\
\hline PB/dia & $\mathrm{Kg}$ & 1,50 & 0,68 & 0,73 & 0,77 \\
\hline $\mathrm{Ca} / \mathrm{dia}$ & $\mathrm{g}$ & 38,76 & 21,00 & 23,00 & 26,00 \\
\hline$P / d i a$ & 9 & 16,00 & 15,00 & 16,00 & 17,00 \\
\hline
\end{tabular}

Fode também ser observado na tabela 7 que 0 consumo de matéria seca permaneceu estável nos três primeiros sub-periodos experimentais, havendo redução a partir do 40 
sub-periodo. O consumo inicial mais elevado pode ser talvez explicado por uin efeito compensatório, já que os animais estavam em regime de pasto durante os 4 meses que antecederam o experimento, e o periodo pré-experimental foi curto, com duração de 25 dias. Outra possivel explicaçăo para a queda de consumo, poderia ser uma possivel alteraçăo na qualidade de um dos ingredientes das dietas. Dentre os ingredientes utilizados, O BTPV é o que estaria mais sujeito a algum tipo de modificação. Apesar das análises bromatológicas não indicarem qualquer modificaça no valor nutritivo dos alimentos, pode ter ocorrido alguma deterioraçăo aeróbica do BTPV pela ação de microrganismos. Visualmente não for am detectadas aiterações no material utilizado, apesar ter se notado a presença de fungos em pontos 1ocalizados. Trabalhos sobre conservação do BTPV são inexistentes, e a ausência de informações sobre o assunto abre a perspectiva de um novo campo de pesquisa sobre este alimento, como mencionado anteriormente. Deve-se ressaltar que apesar da queda observada durante a fase final do experimento, o consumo de matéria seca permaneceu elevado, acima de $126 \mathrm{~g} / \mathrm{kg} \mathrm{PV}^{0,75}$, nivel este que possibilitou a ingeståo de nutrientes em quantidades adequadas, como comentado anteriormente. 
Tabela 7. Efeito do sexo e do sub-periodo experimental sobre o consumo de matéria seca.

\begin{tabular}{|c|c|c|c|}
\hline \multirow{2}{*}{$\begin{array}{l}\text { sub. } \\
\text { periodo }\end{array}$} & \multicolumn{3}{|c|}{ Consumo de $\mathrm{MS} \mathrm{g} / \mathrm{Kg} \mathrm{PV} 0,75$} \\
\hline & Machos & Fêmeas & Médias \\
\hline 1 & $\begin{array}{r}131,67 \\
1,57\end{array}$ & $\begin{array}{rl}139,50 & 1,99\end{array}$ & $\begin{array}{r}135,58^{x} \\
1,26\end{array}$ \\
\hline 2 & $\begin{array}{r}132,14 \\
1,57\end{array}$ & $\begin{array}{r}145,50 \\
1,99\end{array}$ & $\begin{array}{r}138,81^{x} \\
1,26\end{array}$ \\
\hline 3 & $\begin{array}{r}132,60 \\
1,57\end{array}$ & $\begin{array}{r}144,28 \\
1,99\end{array}$ & $\begin{array}{r}138,42^{x} \\
1,26\end{array}$ \\
\hline 4 & $\begin{array}{r}123,45 \\
1,67\end{array}$ & $\begin{aligned} 133,13 \\
2,22\end{aligned}$ & $\begin{array}{r}128,29^{8} \\
1,40\end{array}$ \\
\hline 5 & $\begin{array}{r}120,50 \\
1,77\end{array}$ & $\begin{array}{r}133,14 \\
2,22\end{array}$ & $\begin{array}{r}126,82^{!} \\
1,44\end{array}$ \\
\hline $\begin{array}{r}\text { Medias } \\
5\end{array}$ & $\begin{array}{r}128,07^{\circ} \\
0,73\end{array}$ & $\begin{array}{r}139,09^{b} \\
1,05\end{array}$ & \\
\hline
\end{tabular}

a.b.c - Na mesma linha médias seguizas por ietras diferentes diferem entre si $(P \leq 0,05)$.

$x, y, z$ - Ha mesma coluna médias seguidas por letras diferentes diferent entre si $(P \leq 0,05)$.

A análise de variancia (Tabela 1 do apendice) indicou efeitos significativos das dietas sobre o consumo de matéria seca, mas a interação tratamento periodo não foi significativa. A tabela 8 mostra os valores estimados para o consumo de matéria seca das diferentes dietas dentro dos subperiodos experimentais, e indica que a tendencia de queda de consumo com o decorrer do experimento ocorreu para todas as dietas. Assim sendo, pode-se propor que os aditivos usades não tiveram relação com os fatos observados. 
Tabela 8. Efeito das dietas e dos sub-periodos sobre 0 consumo de MS.

\begin{tabular}{|c|c|c|c|c|c|}
\hline \multirow{2}{*}{$\begin{array}{l}\text { Sub- } \\
\text { periodo }\end{array}$} & \multicolumn{4}{|c|}{ Consumo de $M S \mathrm{~g} / \mathrm{Kg} \mathrm{PV} \mathrm{P}^{0,75}$} & \multirow[b]{2}{*}{ Médias } \\
\hline & $A$ & $B$ & $c$ & $D$ & \\
\hline$s$ & $\begin{array}{r}140,14^{3} \\
2,49\end{array}$ & $\begin{array}{r}128,32^{b} \\
2,49\end{array}$ & $\begin{array}{r}134,83^{a b} \\
2,49\end{array}$ & $\begin{array}{r}139,04^{a} \\
2,49\end{array}$ & $\begin{array}{r}135,58^{x} \\
1,26\end{array}$ \\
\hline$s$ & $\begin{array}{r}140,72^{a c} \\
2,49\end{array}$ & $\begin{array}{r}133,65^{b} \\
2,49\end{array}$ & $\begin{array}{r}134,50^{a b} \\
2,49\end{array}$ & $\begin{array}{r}146,38^{\mathrm{c}} \\
2,49^{1}\end{array}$ & $138,81^{x} 1,26$ \\
\hline$s$ & $\begin{array}{r}137,82^{3} \\
2,49\end{array}$ & $\begin{array}{r}133,61^{2} \\
2,49\end{array}$ & $\begin{array}{r}135,82^{8} \\
2,49\end{array}$ & $\begin{array}{r}146,42^{b} \\
2,49\end{array}$ & $\begin{array}{r}138,41^{x} \\
1,26\end{array}$ \\
\hline 4 & $\begin{array}{r}129,62^{a b} \\
2,49\end{array}$ & $\begin{array}{r}125,72^{2} \\
2,76\end{array}$ & $\begin{array}{r}122,93^{8} \\
2,49\end{array}$ & $134,88^{b}, 16$ & $\begin{array}{l}128,29^{y} \\
1,40\end{array}$ \\
\hline 5 & $\begin{array}{r}129,36^{2} \\
2,76\end{array}$ & $\begin{array}{r}124,07^{a b} \\
2,76\end{array}$ & $\begin{array}{r}122,03^{b} \\
2,49\end{array}$ & $\begin{array}{r}131,83^{2} \\
3,16\end{array}$ & $126,82^{1} 1,44$ \\
\hline $\begin{array}{r}\text { Média } \\
\text { s }\end{array}$ & $\begin{array}{r}135,53^{2} \\
1,17\end{array}$ & $\begin{array}{r}129,07^{b} \\
1,21\end{array}$ & $\begin{array}{r}130,02^{b} \\
1,14\end{array}$ & $\begin{array}{r}139,71^{c} \\
1,27\end{array}$ & \\
\hline
\end{tabular}

a.b.c - Na mesma linha médias seguiáas por ietras diferentes diferen entre si $(P \leq 0,05)$.

$x, y, z$ - Ha mesma coluna médias seguidas por letras diferentes diferent entre si $(P \leq 0,05)$.

4.1.2. Efeito das dietas sobre o consumo

a. Adição de Tasalocida sớdica

Analisando os dados contidos na tabela 8 , e comparando a dieta testemunha $A$ com a dieta $B$, verifica-se que o aditivo lasalocida promoveu uma redução significativa no consumo de matéria seca, de aproximadamente $4,7 \%$. Reduções de $5 \%$ no consumo em presença de lasalocida sódica, estão de acordo com os dados da literatura para bovinos confinados, e O fato parece bem estabelecido para dietas ricas em grãos 
(CHALUPA, 1977; CHALUPA, 1980; BERGEN \& BATES, 1984 e GOODRICH et alii, 1984). Entretanto, observações sobre dietas com niveis intermediários de concentrado são escassas, apesar de SCHELLING (1984) ter citado, em sua revisão, reduções de $3 \%$ no consumo com dietas mais volumosas.

A redução no consumo nos primeiros subperiodos experimentais em que os animais receberam a ração com lasalocida, poderia ser atribuida à falta de adaptação ao aditivo. No presente trabalho os animais não foram adaptados ao ionóforo durante o período pré experimental, ou seja, o aditivo foi introduzido na dieta no primeiro dia do periodo experimental, e em dose normal, porque houve atraso no recebimento do produto. Revisando o uso de ionóforos em dietas para bovinos, SCHELLING (1984) relatou que em animais não adaptados, o teito depressivo do aditivo sobre o consumo era acentuado na fase inicial de fornecimento. O autor mencionou que redução de até $16 \%$ pode ser observada quando o ionóforo é introduzido de forma abrupta e, à medida que ocorre a adaptaçăo, há tendência de redução do efeito depressivo. Esse fato foi observado no presente experimento pois, como pode ser visto na tabela 8 , após 020 sub-periodo experimental não mais ocerreu a mencionada redução.

A tabela 9 mostra o consumo estimado de matéria seca para machos e fémeas nas diferentes dietas testadas. A análise de variancia (Tabela 1 do apêndice) mostrou efeitos significativos para sexo, mas a interação 
dessa variável com as dietas não foi significativa. Pode-se observar, que a tendencia de redução no consumo pela adição de lasalocida (A comparada com B) ocorreu tanto para machos (redução de 5,5\%) quanto para fêmeas (redução de $4,0 \%$ ).

Tabela 9. Efeito do sexo e das dietas sobre o consumo de matéria seca.

\begin{tabular}{|c|c|c|c|}
\hline \multirow[b]{2}{*}{ Dietas } & \multicolumn{3}{|c|}{ Consumo de $M S \mathrm{~g} / \mathrm{Kg} \mathrm{PV} V^{0,75}$} \\
\hline & Machos & Fêmeas & Médias \\
\hline \multirow[t]{2}{*}{$A$} & $129,94^{x}$ & $141,12^{x}$ & $135,53^{x}$ \\
\hline & 1,47 & 1,80 & 1,17 \\
\hline \multirow[t]{2}{*}{$B$} & $122,74^{y}$ & $135,40^{y}$ & $129,07^{!}$ \\
\hline & 1,55 & 1,80 & 1,21 \\
\hline \multirow[t]{2}{*}{$c$} & $125,45^{y}$ & $134,59^{y}$ & $130,02^{!}$ \\
\hline & 1,40 & 1,80 & 1,14 \\
\hline \multirow[t]{2}{*}{$\mathrm{D}$} & $134,15^{2}$ & $145,27^{x}$ & $139,71^{\circ}$ \\
\hline & 1,40 & 2,12 & 1,27 \\
\hline Médias & $128,07^{a}$ & $139,09^{b}$ & \\
\hline$\varepsilon$ & 0,73 & 1,05 & \\
\hline
\end{tabular}

$a, b, c$ - la mesma linha rédias seguidas por letras diferentes diferen entre si $(P \leq 0,05)$.

$x, y, z$ - Na mesma coluna médias seguicas por letras diferentes diferem entre si $(P \leq 0,05)$.

A observação da tabela 10 mostra que o efeito depressivo da lasalocida sódica sobre o consumo de matéria seca por machos e fêmeas, dentro de cada sub-periodo experimental, foi diferente. Pode-se verificar que para os machos foram detectados reduções significativas no 10 (redução de $13,0 \%$ ) e no 20 sub-periodo (reduçăo de $6,8 \%$ ) ao passo que para as fêmeas o efeito não foi observado, apesar dos valores absolutos de consumo terem indicado tendência de 
redução em todos os sub-períodos.

Tabela 10. Efeito do sexo e dos sub-periodos experimentais sobre o consumo das dietas A e B.

\begin{tabular}{|c|c|c|c|c|c|}
\hline \multirow{2}{*}{$\begin{array}{l}\text { Sub- } \\
\text { periodo }\end{array}$} & \multirow[b]{2}{*}{ Dieta } & \multicolumn{4}{|c|}{ Consumo de $M S \mathrm{~g} / \mathrm{Kg} \mathrm{PV}$} \\
\hline & & Machos & $s$ & Fômeas & s \\
\hline 1 & $\begin{array}{l}A \\
B\end{array}$ & $\begin{array}{l}137,93^{x} \\
119,93^{y}\end{array}$ & $\begin{array}{l}3,13 \\
3,13\end{array}$ & $\begin{array}{l}142,34^{x} \\
136,71^{x}\end{array}$ & $\begin{array}{l}3,88 \\
3,88\end{array}$ \\
\hline 2 & $\begin{array}{l}A \\
B\end{array}$ & $\begin{array}{l}13.3,72^{x} \\
124,67^{y}\end{array}$ & $\begin{array}{l}3,13 \\
3,13\end{array}$ & $\begin{array}{l}147,72^{x} \\
142,64^{x}\end{array}$ & $\begin{array}{l}3,88 \\
3,88\end{array}$ \\
\hline 3 & $\begin{array}{l}A \\
B\end{array}$ & $\begin{array}{l}131,46^{x} \\
129,00^{x}\end{array}$ & $\begin{array}{l}3,13 \\
3,13\end{array}$ & $\begin{array}{l}144,19^{x} \\
138,22^{x}\end{array}$ & $\begin{array}{l}3,88 \\
3,88\end{array}$ \\
\hline 4 & $\begin{array}{l}A \\
B\end{array}$ & $\begin{array}{l}123,09^{x} \\
121,87^{x}\end{array}$ & $\begin{array}{l}3,13 \\
3,87\end{array}$ & $\begin{array}{l}136,15^{x} \\
129,57^{x}\end{array}$ & $\begin{array}{l}3,88 \\
3,88\end{array}$ \\
\hline 5 & $\begin{array}{l}A \\
B\end{array}$ & $\begin{array}{l}123,53^{x} \\
118,25^{x}\end{array}$ & $\begin{array}{l}3,87 \\
3,87\end{array}$ & $\begin{array}{l}135,20^{x} \\
129,90^{x}\end{array}$ & $\begin{array}{l}3,83 \\
3,88\end{array}$ \\
\hline
\end{tabular}

$x . y$ - Ha mesma coluna médias seguidas por letras diferentes diferem entre si $(P \leq 0,05)$.

A observação dos efeitos mencionados parece indicar uma maior sensibilidade dos machos em relação ao uso da Tasalocida, principalmente na fase inicial de fornecimento. A literatura revisada não fornece nenhuma referêncía de comportamento diferenciado entre machos e fêmeas à lasalocida. Além desse aspecto, deve-se atentar para - fato que, na tabela 9, quando foi verificado o efeito dos tratamentos sobre o consumo de machos e fêmeas, havia sido detectada uma redução significativa, da ordem de $4,05 \%$ no consumo de fêmeas. O pequeno número de observações real izades para fêmeas pode ter afetado a análise da interação tripla 
para este sexo. Entretanto; trabalhando com dietas seme Thantes às utilizadas neste experimento, SILVA (1990) não obteve efeito depressivo da lasalocida sódica sobre o consumo de matéria seca de vacas leiteiras adaptadas ao ionóforo.

\section{b. Adição de bicarbonato de sódio as lietas contendo lasalocida}

No presente trabaiho não foi possivel caracterizar o efeito isolado do bicarbonato de sódio sobre o consumo de matéria seca. Assim o efeito desse aditivo foi analisado de duas maneiras distintas, ou seja, o efeito da adisăo de bicarbonato em dietas contendo lasalocida (B comparada com D) e o efeito combinado dos dois aditivos (A comparada com D).

Através dos dados inseridos na tabela 8 , podese verificar que a comparação das dietas B $(129,07 \mathrm{~g}$ MS/Kg $\left.P V^{0,15}\right)$ e $D\left(139,71 \mathrm{~g} M S / K g \quad P V^{0,75}\right)$ indicou que na média, a adição de bicarbonato à dieta contendo lasalocida promoveu um aumento significativo no consumo da ordem de $8,2 \%$. Revisando cerca de 40 trabalhos sobre o efeito do bicarbonato de sódio na produção de leite e gordura, STAPLES \& LOUGH (1989) relataram que o incremento de produção poderia estar relacionado com um maior consumo, sendo o efeito observado para dietas contendo alimentos ácidos. Uma das hipóteses para justificar esse efeito seria o aumento na taxa de passagem de alimentos pelo rúmen, devido às alterações na concentração 
osmótica do fluído ruminal, mas o efeito só é observado com niveis muito elevados de bicarbonato, provocando nesse caso redução no consumo (STAPLES \& LOUGH, 1988). Segundo LANNA \& BOIN (1988) a neutralização no cocho dos ácidos existentes no BTPV poderia ser 0 fator a promover o consumo. Outra possibilidade para explicar o incremento de consumo com o BTPV seria o efeito positivo do bicarbonato sobre o ambiente ruminal, favorecendo a taxa de degradação da fração fibrosa no rúmen, fato esse que aumentaria o consumo (LANNA \& BOIN, 1988)

A ausência de efeito positivo do $\mathrm{NaHCO}_{3}$ sobre o consumo de matéria seca de dietas à base de BTPV, contendo (SILVA, 1990) ou não (NUSSIO et alii, 1990) lasalocida pode ser consequência da presença de calcário calcítico de granulometria reduzida, utilizado nas dietas. Trabalhos têm mostrado que calcários calciticos de alta reatividade podem agir como agentes tamponantes a nível de rúmen (WHEELER et alii, 1981b; TEH et a1ii, 1985).

Anal isando na tabela 8 o efeito do bicarbonato sobre as dietas contendo lasalocida (B comparada com D), observa-se que o efeito significativo de aumento de consumo ocorreu no 4 rimeiros sub-períodos experimentais. No 59 subperiodo experimental o nivel de significância detectado para a dfferenga foi de $P<0,08$. Assim sendo pode-se considerar que também na fase final do experimento houve tendência de aumento. Essas observações não estão de acordo com a 
1 iteratura, já que revisando o assunto WHEELER (1980) relatou que, de modo geral, o efeito benéfico do bicarbonato sobre o consumo ocorre principalmente na fase inicial do fornecimento. Trabalhando com dietas à base de BTPV, LANNA \& BOIN (1988) também verificaram efeito positivo do bicarbonato apenas na fase inicial do experimento. Deve-se ressaltar que no presente experimento o efeito do bicarbonato foi avaliado na presença de lasalocida sódica, que pode talvez afetar o padra de reposta dos animais à presença do bicarbonato.

Na tabela 9, pode-se verificar que o efeito significativo do $\mathrm{NaHCO}_{3}$ sobre o consumo da dieta contendo lasalocida (B comparada com D), foi observado tanto para machos quant para fêmeas. Para o caso dos machos o aumento foi de $9,3 \%$, enquanto que para as fêmeas o incremento foi de 7,3\%. Trabalhando com animais semelhantes aos do presente experimento, LANNA e BOIN (1988) não verificaram efeito de $\mathrm{NaHCO}_{3}$ sobre o consumo de fêmeas recebendo dietas sem a adiçăo de lasalocida.

Verifica-se na tabela 11, que a análise do efeito do $\mathrm{NaHCO}_{3}$ sobre o consumo de machos e de fêmeas dentro de cada sub-periodo experimental, indicou efeitos diferentes. os dados parecem indicar que os efeitos foram bem pronunciados nos machos, já que ocorreram diferenças significativas nos três primeiros sub-periodos experimentais, ao passo que para as fêmeas, a análise estatistica não indicou incrementos significativos, apesar de se observar 
tendência de aumento pela análise dos dados coletados. Como discutido anteriormente, o pequeno número de observações realizadas para fêmeas, pode não ter sido suficiente para detectar efeitos significativos. Tomando-se por base a análise, aparece também neste caso a sugestão de que os machos foram mais sensiveis que as fêmeas à açăo do bicarbonato de sódio.

Na análise dos dados inseridos na tabela 11, aparece a tendência relatada na literatura de que o efeito benéfico do bicarbonato ocorre principalmente na fase inicial de fornecimento (WHEELER, 1980; LANNA \& BOIN, 1988), sendo o efeito caracterizado para os machos.

Tabela 11. Efeito do sexo e dos sub-periodos experimentais sobre as dietas $B \in D$.

\begin{tabular}{cccccc}
\hline \multirow{2}{*}{$\begin{array}{c}\text { Sub- } \\
\text { periodo }\end{array}$} & Dietas & Machos & s & Fêmeas & S \\
\cline { 2 - 6 } & B & $119,93^{x}$ & 3,13 & $136,71^{x}$ & 3,88 \\
\hline 1 & D & $134,44^{y}$ & 3,13 & $143,64^{x}$ & 3,88 \\
2 & B & $124,67^{x}$ & 3,13 & $142,64^{x}$ & 3,88 \\
& D & $141,20^{y}$ & 3,13 & $151,55^{x}$ & 3,88 \\
3 & B & $129,00^{x}$ & 3,13 & $138,22^{x}$ & 3,88 \\
& D & $142,27^{y}$ & 3,13 & $150,56^{y}$ & 3,88 \\
4 & B & $121,87^{x}$ & 3,88 & $129,57^{x}$ & 3,88 \\
& D & $128,92^{x}$ & 3,13 & $140,84^{x}$ & 5,49 \\
5 & B & $118,25^{x}$ & 3,88 & $129,90^{x}$ & 3,88 \\
& D & $123,91^{x}$ & 3,13 & $139,75^{x}$ & 5,49 \\
\hline
\end{tabular}

$x, y$ - ha mesma coluna médias sezuidas por letras diferentes diferem entre si $(P \leq 0,05)$. 
Considerando na tabela 8 a comparação entre as dietas $D$ e $A$, verifica-se que houve um efeito significativo da associação dos dois aditivos testados, aumentando o consumo de matéria seca em $3,1 \%(D=139,71$ e $A=135,53 \mathrm{~g} / \mathrm{Kg}$ $\left.P V^{(i s}\right)$. Na mesma tabela pode-se observar que houve uma tendência de efeito positivo em todos os sub-períodos, mas efeito significativo somente no terceiro. Como discutido anteriormente a adiçăo de lasalocida sódica reduziu o consumo de matéria seca na fase inicial de fornecimento da dieta, enquanto que efeitoda adição de $\mathrm{NaHCO}_{3}$ ocorreu em todos os sub-periodos. Os dados indicam que 0 bicarbonato em assoolacáa com a lasalocida, foi capaz de evitar o efeito depressivo do ionóforo sobre consumo de matéria seca na fase inicial, favorecendo assim a adaptação dos animais.

Os dados da tabela 9 mostram que a associação do $\mathrm{NaHCO}_{3}$ com - ionóforo (D comparado com A) promoveu aumentos significativos no consumo de matéria seca dos machos da ordem de $3,2 \%\left(D=134,15\right.$ e $\left.A=129,94 \mathrm{~g} / \mathrm{Kg} \mathrm{PV}^{0,15}\right)$ ao passo que para as fèmeas a análise estatística não detectou aumentos significativos $(2,94 \%)$.

A tabela 12 mostra o efeito das dietas e de sexo dentro dos sub-periodos experimentais e indica que, como nos desdobramentos anteriores, o efeito associado (D comparada com A) do bicarbonato e da lasalocida promoveu resultados diferentes em machos e fêmeas. 
Tabela 12. Efeito do sexo e dos sub-períodos experimentais sobre o consumo das dietas $A$ e D.

\begin{tabular}{|c|c|c|c|c|c|}
\hline \multirow{2}{*}{$\begin{array}{l}\text { Sub } \\
\text { periodo }\end{array}$} & \multirow[b]{2}{*}{ Dietas } & \multicolumn{4}{|c|}{ Consumo de $M S \mathrm{~g} / \mathrm{Kg} \mathrm{PV}$} \\
\hline & & Machos & $s$ & Fêmeas & $s$ \\
\hline 1 & $\begin{array}{l}A \\
D\end{array}$ & $\begin{array}{l}137,92^{x} \\
134,44^{x}\end{array}$ & $\begin{array}{l}3,13 \\
3,13\end{array}$ & $\begin{array}{l}142,35^{x} \\
143,64^{x}\end{array}$ & $\begin{array}{l}3,88 \\
3,88\end{array}$ \\
\hline 2 & $\begin{array}{l}A \\
D\end{array}$ & $\begin{array}{l}133,72^{x} \\
141,20^{x}\end{array}$ & $\begin{array}{l}3,13 \\
3,13\end{array}$ & $\begin{array}{l}147,72^{x} \\
151,55^{x}\end{array}$ & $\begin{array}{l}3,88 \\
3,88\end{array}$ \\
\hline 3 & $\begin{array}{l}A \\
D\end{array}$ & $\begin{array}{l}131,46^{x} \\
142,27^{y}\end{array}$ & $\begin{array}{l}3,13 \\
3,13\end{array}$ & $\begin{array}{l}144,19^{x} \\
150,56^{x}\end{array}$ & $\begin{array}{l}3,88 \\
3,88\end{array}$ \\
\hline 4 & $\begin{array}{l}A \\
D\end{array}$ & $\begin{array}{l}123,09^{x} \\
128,92^{x}\end{array}$ & $\begin{array}{l}3,13 \\
3,13\end{array}$ & $\begin{array}{l}136,15^{x} \\
140,85^{x}\end{array}$ & $\begin{array}{l}3,88 \\
5,49\end{array}$ \\
\hline 5 & $\begin{array}{l}A \\
D\end{array}$ & $\begin{array}{l}123,53^{x} \\
123,91^{x}\end{array}$ & $\begin{array}{l}3,88 \\
3,13\end{array}$ & $\begin{array}{l}135,20^{x} \\
139,75^{x}\end{array}$ & $\begin{array}{l}3,88 \\
5,49\end{array}$ \\
\hline
\end{tabular}

x.y - Na mesma coluna médias seguidas por letras diferentes diferem entre si $(P \leq 0,05)$.

Para o caso dos machos, o aumento significativo no consumo de matéria seca pelo efeito associado de lasalocida sódica e do bicarbonato, só apareceu no 30 sub-periodo experimental, de acordo com a informação já discutida dos dados contidos na tabela 8. Para as fêmeas pode ser notado novamente a tendência de aumento em todos os subperiodos, sem a caracterização de diferença significativa, como ocorrida anteriormente.

Com base nas comparaçôes efetuadas entre os efeitos das dietas sobre o consumo de matéria seca $(A \times B, B$ $\times D$, e $A \times D)$, pode-se concluir que o bicarbonato de sódio foi capaz de anular o efeito depressivo da lasalocida. o mecanismo pelo qual o $\mathrm{NaHCO}_{3}$ pode anular ou reduzir o efeito deressivo do ionóforo sobre o consumo $e$ desconhecido, mas 
existem informações sobre o fato de que a lasalocida reduz o consumo afetando a taxa de passagem ruminal, através da redução na taxa de degradação da porção fibrosa, principalmente de animais não adaptados (RUSSELL \& STROBEL, 1989), alteração na osmolalidade do fluído ruminal (STARNES et alii, 1984), e redução no número e força das contrações do trato digestivo (DESWYSEN \& ELLIS, 1988). Não existem na 7 iteratura informações quanto ao efeito do $\mathrm{NaHCO}_{3}$ sobre as contrações do trato digestivo. Com respeito a osmolalidade do fluido ruminal STAPLES e LOUGH (1989) afirmam que esta não é afetada por niveis de $\mathrm{NaHCO}_{3}$ entre 0,7 a $1,5 \%$ da MS da dieta, porém, a degradação da fração fibrosa da dieta pode ser afetada pelo $\mathrm{NaHCO}_{\hat{j}}$. Assim sendo, em dietas à base de BTPV, onde a fraço fibrosa é considerável, o $\mathrm{NaHCO}_{3}$ poderia talvez reduzir o efeito depressivo do ionóforo sobre a taxa de degradação desta fração na fase inicial de fornecimento do aditivo. Pode-se propor que a manutenção de um pH ruminal actima de 6, o criaria uma condição mais favorável às bactérias celuloliticas sensiveis ao ionóforo, como Ruminococcus e Butyrovibrio, como também poderia acelerar a taxa de crescimento (reduzir o "lag time") de bactérias pouco sensiveis ao ionóforo como Bacteroides sUccinogenes (RUSSELL \& STROBEL, 1989). Esses fatos poderiam permitir uma adptação mais rápida dos animais ao ionóforo. SILVA (1990) não verificou efeito depressivo da lasalocida sódica sobre o consumo de matéria seca de vacas leiteiras recebendo dietas 
à base de BTPV, quando o pH médio do fluído ruminal foi de 6.74. Alem desse aspecto, a literatura indica que o efeito depressivo do ionóforo é maior em dietas ricas em grãos, onde - pH ruminal é mais baixo (CHALUPA, 1977; BERGEN \& BATES, $1984)$.

c) Ausència de cana-de-açúcar em dietas contendo lasalocida e bicarbonato.

Tomando-se come base os dados inseridos na tabela 8, pode-se verificar que a comparaçăo entre as dietas $\mathrm{D}\left(139,71 \mathrm{~g} / \mathrm{Kg} P V^{0.15}\right)$ e $\mathrm{C}\left(130,02 \mathrm{~g} / \mathrm{kg} \mathrm{PV}^{0,75}\right)$ indicou uma redução significativa no consumo de matéria seca da ordem de $6,9 \%$, quando a cana-de-açúcar picada foi retirada da dieta à base de BTPV contendo lasalocida e bicarbonato. Na realidade, o major vator estimado de consumo foi para a dieta $D$, havendo uma tendência de se observar esse fato em praticamente todos os sub-periedos experimentais, com exceçăo do primeiro. Podese também verificar consumos elevados para a dieta $A$, onde os animais receberam a dieta de BTPV sem aditivos mas com cana picada.

A análise detalhada dos dados contidos na tabela 8 , indica que efeitos significativos da retirada da cana picada sobre o consumo só foram observados à partir do segundo sub-período experimental. Esse fato pode estar relacionado com a ação depressiva do ionóforo na fase 
inicial, como discutido anteriormente, e ao fato do bicarbonato ter mostrado efeito positivo sobre o incremento no consumo de matéria seca no tratamento T3.

o efeito negativo da retirada da cana-deaçúcar picada sobre o consumo de matéria seca, poderia ser atribuido ao efeito fisiológico da fração fibrosa no rúmen e no trato digestivo inferior, pois o tratamento sob pressão de vapor reduz o tamanho da particulas do bagaço e aumenta a sua friabilidade (BURGI, 1985). Esse fato pode limitar a atuação da fração fibrosa do BTPV no estímuio à ruminação e ao peristaltismo intestinal (CASTRO, 1989).

Pode-se sugerir, com base em observações de campo, não sistemáticas, que a cana pode ter também atuado como um agente palatabilizante. Durante a condução do ensaio, foi observado que após a distribuição do alimento, os animais recebendo dietas contendo cana-de-açúcar, dirigiam-se ao cocho rapidamente, e comecavam a comer antes de todos os outros. Essa suposicão pode ser de certa maneira suportada pelo rato de que nos experimentos onde a fonte de fibra integra era o bagaço de cana, sem tratamento, não houve estimulo de consumo (SILVA, 1990), talvez por ser esse volumoso de baixa alatabilidade.

Na tabela 9 pode-se verificar que, tanto para os machos quanto para as fêmeas, a retirada de cana picada. reduziu significativamente o consumo de matéria seca ( $D$ comparada com C). Para o caso dos machos, a redução foi de 
$6,5 \%\left(D=134,15\right.$ e $\left.C=125,45 \mathrm{~g} / \mathrm{Kg} \mathrm{PV} V^{0,75}\right)$ enquanto que para as fameas, a reduça foi de $7,3 \%(D=145,27$ e $C=134,59$ $\left.\mathrm{g} / \mathrm{kg} P v^{0,75}\right)$. Na média, o consumo da dieta $\mathrm{C}(130,02 \mathrm{~g} / \mathrm{kg}$ - $v^{0,15}$ foi significativamente inferior ao consumo da dieta $D$ $\left(139.71 \mathrm{~g} / \mathrm{Kg} \mathrm{PV} \mathrm{V}^{0.15}\right)$, sendo a diferença da ordem de $6.9 \%$.

A andise da tabela 13 , mostra que a reduçao no consum de matéria seca observada para machos e fêmeas dentro de cada sub-periodo experimental foi diferente. Podese verificar que para os machos os efeitos significativos de redução no consumo de matéria seca só apareceram a partir do 20 sub-periodo, permanecendo o efeito até o 40. Para o caso das fêmeas o efeito foi menos evidente. Apesar desse fato, deve-se observar que a tendência de redução foi nítida em todos os sub-periodos para as fêmeas, mas não para os machos, onde no primeiro sub-periodo não apareceu a tendência. Esse fato pode estar associado com a maior sensibilidade dos machos à lasalocida, como discutida anteriormente.

\section{Levando-se em consideração o elevado consumo} da dieta C (adição de lasalocida e bicarbonato, sem cana picada), da ordem de $130 \mathrm{~g} \mathrm{MS/Kg} \mathrm{PV}^{0,15}$, e a ausência de distúrbios digestivos durante o experimento, pode-se propor que a adição de cana picada às dietas de BTPV, comuns em confinamentos comerciais, pode ser dispensada quando a ração contem lasalocida e bicarbonato. 
Tabela 13. Efeito do sexo e dos sub-períodos experimentais sobre o consumo das dietas C e D.

\begin{tabular}{|c|c|c|c|c|c|}
\hline \multirow{2}{*}{$\begin{array}{l}\text { Sub- } \\
\text { periodo }\end{array}$} & \multirow[b]{2}{*}{ Dietas } & \multicolumn{4}{|c|}{ Consumo de $\mathrm{MS} \mathrm{g} / \mathrm{Kg} \mathrm{PV} \mathrm{PV}^{0,75}$} \\
\hline & & Machos & $s$ & Fêmeas & $s$ \\
\hline 1 & $\begin{array}{l}C \\
D\end{array}$ & $\begin{array}{l}134,38^{x} \\
134,43^{x}\end{array}$ & $\begin{array}{l}3,13 \\
3,13\end{array}$ & $\begin{array}{l}135,29^{x} \\
143,64^{x}\end{array}$ & $\begin{array}{l}3,88 \\
3,88\end{array}$ \\
\hline 2 & $\begin{array}{l}C \\
D\end{array}$ & $\begin{array}{l}128,97^{x} \\
141,20^{y}\end{array}$ & $\begin{array}{l}3,13 \\
3,13\end{array}$ & $\begin{array}{l}140,02^{x} \\
151,55^{y}\end{array}$ & $\begin{array}{l}3,88 \\
3,88\end{array}$ \\
\hline 3 & $\begin{array}{l}C \\
D\end{array}$ & $\begin{array}{l}127,67^{x} \\
142,27^{y}\end{array}$ & $\begin{array}{l}3,13 \\
3,13\end{array}$ & $\begin{array}{l}143,98^{x} \\
150,57^{x}\end{array}$ & $\begin{array}{l}3,88 \\
3,88\end{array}$ \\
\hline 4 & $\begin{array}{l}C \\
D\end{array}$ & $\begin{array}{l}119,92^{x} \\
128,92^{y}\end{array}$ & $\begin{array}{l}3,13 \\
3,13\end{array}$ & $\begin{array}{l}125,94^{x} \\
140,84^{y}\end{array}$ & $\begin{array}{l}3,88 \\
5,49\end{array}$ \\
\hline 5 & $\begin{array}{l}C \\
D\end{array}$ & $\begin{array}{l}116,32^{x} \\
123,91^{x}\end{array}$ & $\begin{array}{l}3,13 \\
3,13\end{array}$ & $\begin{array}{l}127,74^{x} \\
139,74^{x}\end{array}$ & $\begin{array}{l}3,88 \\
5,49\end{array}$ \\
\hline
\end{tabular}

$x, y$ - La mesma coluna médias seguidas por letras diferentes diferem entre si $(p \leq 0,05)$.

4.2. Ganho de peso vivo diário

4.2.1. Nivel e comportamento de ganho de peso

\begin{abstract}
A análise de variancia (Tabela 2 do apêndice) revelou que o ganho de peso diário estimado no presente esperimento, so fol afetado significativamente pelo sexo e por aub-perfodo. A tabela 14, apresenta o ganho de peso diário de machos e fêmeas nos diferentes sub-periodos experimentais e indica que os machos ganharam significativamente mais peso (25\%) do que as fêmeas. Essas observaçôes estão de acordo com o esperado, já que inúmeros trabathes de pesquisa revelam que os machos são capazes de
\end{abstract}


ganhar mais peso que as fêmeas da mesma raça (SILVEIRA \& DOMINGUES, 1978; ROCHE \& QUIRKE, 1986; LANNA \& BOIN, 1988; Nussio et alii, 1990), devido à secreção de hormonios esteróides sexuais, principalmente testosterona (R CHE : QUIRKE, 1986).

Tabela 14. Ganho de peso diário de machos e fêmeas.

\begin{tabular}{|c|c|c|c|c|}
\hline \multirow{2}{*}{$\begin{array}{l}\text { Sul- } \\
\text { período }\end{array}$} & & \multicolumn{3}{|c|}{ Ganho diário em $\mathrm{kg}$} \\
\hline & & Machos & Fêmeas & Medias \\
\hline 1 & $s$ & $\begin{array}{l}1,11^{x y} \\
0,084\end{array}$ & $\begin{array}{l}0,93^{x y} \\
0,128\end{array}$ & $1,02^{x} 0,082$ \\
\hline 2 & s & $\begin{array}{l}1,63^{2} \\
0,082\end{array}$ & $\begin{array}{l}1,26^{2} \\
0,115\end{array}$ & $\begin{array}{r}1,44^{y} \\
0,069\end{array}$ \\
\hline 3 & s & $\begin{array}{l}1,40^{2} \\
0,098\end{array}$ & $\begin{array}{l}1,23^{2} \\
0,104\end{array}$ & $\begin{array}{l}1,31^{y z} \\
0,068\end{array}$ \\
\hline 4 & s & $\begin{array}{l}1,42^{x z} \\
0,129\end{array}$ & $\begin{array}{l}0,88^{y} \\
0,115\end{array}$ & $\begin{array}{l}1,15^{x z^{\prime}} \\
0,091\end{array}$ \\
\hline 5 & s & $\begin{array}{l}1,09^{y} \\
\quad 0,166\end{array}$ & $\begin{array}{l}1,03^{y z} \\
0,121\end{array}$ & $\begin{array}{r}1,06^{x} \\
0,116\end{array}$ \\
\hline Médias & $s$ & $\begin{array}{l}1,33^{\mathrm{a}} \\
0,067\end{array}$ & $\begin{array}{l}1,06^{b} \\
0,057\end{array}$ & \\
\hline
\end{tabular}

a.b - Na mesma linha médias seguinas por letras diferentes diferem entre si $(P \leq 0,05)$.

$x, y, z$ - ta mesma coluna nédias seguidas por letras diferentes diferem entre si $(P \leq 0,05)$.

Com os dados inseridos na tabela 14, pode-se verificar que o ganho de peso do lote experimental durante os 66 dias de confinamento foi de $1,20 \mathrm{~kg} / \mathrm{cab} / \mathrm{dia}$. Este nivel pode ser considerado muito bom, principalmente levando-se em conta que $40 \%$ dos animais eram fêmeas. Deve-se mencionar que 
o ganho dos machos está de acordo com a expectativa estimada de consumo de nutrientes (Tabela 6), como discutido anteriormente, enquanto o ganho de peso das fêmeas não foi compativel com o elevado consumo verificado. As estimativas indicam que dietas contendo $60 \%$ de BTPV e 40\% de concentrado com base na matéria seca possibilitam desempenho satisfatório de bovinos com idade inferior a 20 meses. Sem dúvida, como apontado anteriormente, o elevado consumo de matéria seca das dietas contribuiu para a obtenção de ganhos satisfatórios:

Para a análise de ganho de peso, deve-se atentar para o fato de que durante os 4 meses que antecederam o experimento, os animais ermaneceram em regime de pasto, onde o ritmo de crescimento foi reduzido, porque haviam saido de um confinamento de 107 dias, onde ganharam 0,930 $\mathrm{kg} / \mathrm{cab} / \mathrm{dia}$. Colocados novamente no confinamento, durante o periodo pré-experimental de 25 dias, ganharam 1,16 $\mathrm{kg} / \mathrm{cab} / \mathrm{dia}$, ao passo que no primeiro sub-periodo experimental, o ganho médio foi reduzido para $1,02 \mathrm{~kg} / \mathrm{cab} / \mathrm{dia}$ (Tabela 14), talvez devido ao efeito depressivo do ionóforo, reduzindo o consumo de alimento (Tabela 9). Nos sub-períodos 2 e 3 , os ganhos de peso foram bastante elevados (Tabela 14) tanto para fêmeas quanto para machos, atingindo uma média $1,44 \mathrm{~kg} / \mathrm{cab} / \mathrm{dia}$ e $1,31 \mathrm{~kg} / \mathrm{cab} / \mathrm{dia}$, respectivamente. Esses fatos permitem sugerir a possibitidade de ter ocorrido nessa fase um efelto de ganho compensatório. Em condiçóes normais o concumo de $132,14 \mathrm{~g}$ de $M S / K g$ PV 0,75 pelos machos (Tabela 7) 
durante 0 20 sub-periodo, dificilmente permitiria ganhos diários da ordem de $1,63 \mathrm{~kg} /$ cabeça (NRC, 1984), principalmente considerando que cerca de 45 a $50 \%$ do NDT estimado da dieta era proveniente do BTPV. O ganho verificado para os machos durante 05 g sub-período experimental, onde provavelmente já não havia mais efeito do ganho compensatório, pode ser considerado satisfatório.

Na análise dos ganhos de peso elevados obtidos no presente experimento, deve-se considerar ainda o fato de que animais zebuinos bem alimentados, entre 15 e 20 meses, provaveimente encontram-se na fase da puberdade. Sabe-se que esta a fase onde o ritmo de crescimento é máximo (SILVEIRA e DOMINGUES, 1978), e assim sendo, os animais apresentavam condigōes ideais para um bom desempenho.

4.2.2. Efeito das dietas sobre o ganho de peso a. Adição de lasalocida sódica

A tabela 15 mostra o efeito das dietas sobre - ganho de peso. Pode-se observar, na comparação entre as dietas $B$ e A, que a adição de lasalocida sódica não afetou o ganho diário. Além disso, a ausência de efeito ocorreu tanto para machos quanto para fêmeas. A análise de variancia (Tabela 2 do apêndice) não indicou interaçăo significativa entre essas variáveis.

A observação de que o ganho diário não foi 
aumentado pela adiça do ionóforo esta em desacordo com a 1iteratura, pois CHALUPA (1977) e GOODRICH et alii (1984) relataram aumentes superiores a $13 \%$ para animais recebendo dietas mais volumosas adicionadas de ionóforos. Deve-se atentar que ocorreu em machos uma tendência (não significativa) de aumento no ganho de peso. A curta duração do experimento ( 66 dias), o número reduzido de observações e o elevado coeficiente de variaçăo para ganho de peso, podem ter contribuido para que não fossem caracterizados efeitos esperados.

Tabela 15. Efeito do sexo e das dietas sobre o ganho de peso.

\begin{tabular}{|c|c|c|c|}
\hline \multirow[b]{2}{*}{ - ietas } & \multicolumn{3}{|c|}{ Ganho diário em $\mathrm{kg}$} \\
\hline & Machos & Fêmeas & Médias \\
\hline A & $\begin{array}{l}1,25 \\
\quad 0,094\end{array}$ & $\begin{array}{l}1,04 \\
0,095\end{array}$ & $\begin{array}{l}1,15^{x} \\
0,063\end{array}$ \\
\hline$B$ & $\begin{array}{l}1,33 \\
0,095\end{array}$ & $\begin{array}{l}1,00 \\
0,096\end{array}$ & $\begin{array}{l}1,17^{x} \\
0,064\end{array}$ \\
\hline$c$ & $\begin{array}{l}1,29 \\
0,092\end{array}$ & $\begin{array}{l}1,07 \\
0,094\end{array}$ & $\begin{array}{l}1,18^{x} \\
0,063\end{array}$ \\
\hline $\mathrm{D}$ & $\begin{array}{l}1,44 \\
0,093\end{array}$ & $\begin{array}{l}1,15 \\
0,110\end{array}$ & $\begin{array}{l}1,30^{x} \\
0,069\end{array}$ \\
\hline $\begin{array}{r}\text { Médias } \\
\text { S }\end{array}$ & $\begin{array}{l}1,33^{a} \\
0,067\end{array}$ & $\begin{array}{c}1,06^{b} \\
0,057\end{array}$ & \\
\hline
\end{tabular}

$a, b$ - Na mesma linha médias seguidas por letras diferentes diferen entre si $(P \leq 0,05)$.

$x, y$ - Na mesma coluna médias sezuidas por letras diferentes diferen entre si $(P \leq 0,05)$.

Na tabela 16, pode ser observado o efeito das dietas sobre o ganho diário de machos e fêmeas dentro de cada 
sub-periodo experimental. Pode ser visto que a adição de lasalocida sódica à dieta básica de BTPV (A) reduziu significativamente o ganho diário dos machos na fase inicial do trabalho, ou seja, quando os animais năo estavam adaptados, tendo seu desempenho prejudicado pela introdução abrupta do ionóforo na dieta ao nivel de 24,6 ppm da matéria seca. Para o caso das fêmeas a tendência de redução não foi significativa, talvez devido ao número reduzido de observações e o elevado coeficiente de variação verificado.

Tabela 16. Efeito do sexo e dos sub-periodos experimentais sobre o ganho de peso nas dietas $A$ e $B$.

\begin{tabular}{cccccc}
\hline \multirow{2}{*}{$\begin{array}{c}\text { Sub- } \\
\text { período }\end{array}$} & Dietas & Machos & s & Fêmeas & s \\
\cline { 3 - 6 } 1 & A & $1,35^{x}$ & 0,16 & $0,94^{x}$ & 0,21 \\
& B & $0,79^{y}$ & 0,16 & $0,60^{x}$ & 0,21 \\
2 & A & $1,39^{x}$ & 0,16 & $1,25^{x}$ & 0,21 \\
& B & $1,66^{x}$ & 0,16 & $1,34^{x}$ & 0,21 \\
3 & A & $1,20^{x}$ & 0,17 & $1,07^{x}$ & 0,20 \\
& B & $1,37^{x}$ & 0,17 & $1,21^{x}$ & 0,20 \\
4 & A & $1,24^{x}$ & 0,19 & $0,68^{x}$ & 0,20 \\
& B & $1,43^{x}$ & 0,22 & $0,66^{x}$ & 0,20 \\
& A & $1,07^{x}$ & 0,24 & $1,26^{x}$ & 0,20 \\
& B & $1,39^{x}$ & 0,24 & $1,19^{x}$ & 0,24 \\
\hline
\end{tabular}

$x_{1} y-H_{a}$ mesma coluna médias saguidas por letras diferentes diferem entre si $(P \leq 0,05)$.

Apenas a redução no consumo de matéria seca de cerca de 13,0\% (Tabela 10), devido à inclusão do ionóforo na dieta, talvez não explique totalmente a queda de ganho de peso de $41,5 \%$ observada para os machos na dieta $B$ (Tabela 16) 
no 10 sub-perfodo experimenta1. Pode-se também observar que para as fôneas, apesar de não ter sido identificada sianiflcâncta, a reduça foi de $36,2 \%$. O consumo de $119,93 \mathrm{~g}$ MS $/ \mathrm{Kg} \mathrm{PV}$ P.is para os machos e de $136,71 \mathrm{~g}$ MS/Kg PV ${ }^{0,15}$ para as fêmeas (Tabe1a 10) durante o 10 sub-período, seria suficiente para permitir ganhes bem mais elevados que os observados. Sabe-se que a eficiencia da utilizaçăo do arimento é prejudicada quando o animal ainda năo está adaptado ao ionóforo (SCHELLING, 1984; GOODRICH et alii, 1984), e o efeito deve ser pronunciado nas dietas ricas em alimentos fibrosos, como o BTPV.

b. Adição de bicarbonato de sódio às dietas contendo lasalocida

A observação da Tabela 15 permite ver que a comparação entre as dietas $B$ e $D$ indica que a adição de $\mathrm{NaHCO}_{3}$ em uma dieta contendo lasalocida năo promoveu aumentos significativos no ganho de peso dos bovinos confinados. Entretanto, torna-se possivel verificar que houve tendência de aumento tanto para o grupo dos machos quanto para o grupo das fêmeas, como também, para a média dos tratamentos ( $11 \%$ de incremento). Na realidade, era de se esperar uma elevação do ganho de peso, pois como discutido anteriormente (Tabela 8), a adição do bicarbonato à dieta contendo lasalocida elevou significativamente o consumo de matéria seca em $8,2 \%$, e a 
Titeratura mostra efeitos benéficos do uso de $\mathrm{NaHCO}_{\hat{j}}$ sobre a ingestão de matéria seca (STAPLES \& LOUGH, 1989; LANNA \& BOIN, 1988).

Na Tabe Ia 17 , pode-se observar que houve no 19 sub-periodo aumento significativo no ganho de peso dos bovinos que receberam bicarbonato de sódio na dieta (D), quando comparado com aqueles que receberam a ração básica contendo lasalocida (B), sendo o incremento da ordem de $67,1 \%$.

Tabela 17. Efeito das dietas e dos sub-periodos sobre o ganho de peso.

\begin{tabular}{|c|c|c|c|c|c|}
\hline \multirow{2}{*}{$\begin{array}{l}\text { Sub- } \\
\text { período }\end{array}$} & \multicolumn{4}{|c|}{ Ganho diário em $\mathrm{kg}$} & \multirow[b]{2}{*}{ Médias } \\
\hline & $A$ & $B$ & $c$ & D & \\
\hline S & $\begin{array}{l}1,15^{3} \\
0,14\end{array}$ & $\begin{array}{l}0,70^{b} \\
0,14\end{array}$ & $\begin{array}{l}1,08^{a} \\
0,14\end{array}$ & $\begin{array}{l}1,17^{\mathrm{a}} \\
0,14\end{array}$ & $\begin{array}{l}1,02^{x} \\
.0,082\end{array}$ \\
\hline s & $\begin{array}{l}1,32^{a} \\
0,13\end{array}$ & $\begin{array}{l}1,50^{2} \\
0,13\end{array}$ & $\begin{array}{l}1,38^{a} \\
0,13\end{array}$ & $\begin{array}{l}1,57^{a} \\
0,14\end{array}$ & $\begin{array}{r}1,44^{x} \\
0,069\end{array}$ \\
\hline 3 & $\begin{array}{l}1,14^{a} \\
0,13\end{array}$ & $\begin{array}{l}1,29^{a} \\
0,13\end{array}$ & $\begin{array}{l}1,34^{a} \\
0,13\end{array}$ & $\begin{array}{l}1,49^{\mathrm{a}} \\
0,13\end{array}$ & $\begin{array}{l}1,31^{x} \\
0,068\end{array}$ \\
\hline 4 & $\begin{array}{l}0,96^{\mathrm{a}} \\
0,14\end{array}$ & $\begin{array}{c}1,04^{3 b} \\
0,15\end{array}$ & $\begin{array}{l}1,22^{a b} \\
0,14\end{array}$ & $\begin{array}{r}1,39^{b} \\
0,17\end{array}$ & $\begin{array}{r}1,15^{x} \\
0,091\end{array}$ \\
\hline 5 & $\begin{array}{c}1,17^{3 b} \\
0,17\end{array}$ & $\begin{array}{l}1,29^{2} \\
0,16\end{array}$ & $\begin{array}{l}0,89^{b} \\
0,16\end{array}$ & $\begin{array}{r}0,88^{a b} \\
0,19\end{array}$ & $\begin{array}{r}1,06^{x} \\
0,116\end{array}$ \\
\hline $\begin{array}{r}\text { Media } \\
\text { s }\end{array}$ & $\begin{array}{l}1,15^{3} \\
0,063\end{array}$ & $\begin{array}{l}1,17^{2} \\
0,064\end{array}$ & $\begin{array}{l}1,18^{a} \\
0,063\end{array}$ & $\begin{array}{l}1,30^{a} \\
0,069\end{array}$ & \\
\hline
\end{tabular}

$a, b, c$ - Na mesma linha médias seģuidas por letras diferentes diferem entre si $(P \leq 0,05$.

$x, y$ - lla mesma coluna médias seguidas oor letras diferentes diferen entre si $<\leqslant \leq 0,05$. 
O efeito bastante pronunciado do $\mathrm{NaHCO}_{3}$ sobre - ganho diário durante 0 10 sub-periodo experimetnal está de acordo com as observações de WHEELER (1980) que relatou que o efeito benéfico dos a entes tamponantes sobre o desempenho dos bovinos manifesta-se principalmente na fase inicial do fomecimento. Os dados de LANNA \& BOIN (1988), utitizando dietce com 55\% de BTPV, 5\% de BIN e $40 \%$ de concentrado, na base de matéria seca, também indicaram efeito positivo do NaHCO, sobre ganho na fase inicial do fornecimento da dieta. Deve-se atentar para o fato de que houve tendencia de melhor desempenho do lote recebendo a dieta $D$ até o 40 sub-periodo. Esse melhor desempenho pode ser atribuído ao fato de que o consumo de matéria seca foi significativamente maior para a dieta D comparada com B (Tabela 8), aparecendo também a tendência de maior consumo durante todo o periodo experimental. Como discutido anteriormente, a adicão de $\mathrm{NaHCO}_{3}$ à dietas de BTPV contendo lasalocida pode elevar o consumo e resultar em melhor desempenho animal.

A Tabela 18 sumariza o efeito das dietas sobre o ganho de peso diário de machos e fêmeas dentro de cada subperiodo experimental. Pode-se observar que tanto nos machos como nas fêmeas o efeito do $\mathrm{NaHCO}_{3}$ sobre o ganho de peso ocorreu principalmente durante o 10 sub-periodo experimental, sendo o efeito significativo somente para as fêmeas. Entretanto, pode-se observar que houve tendência de ganhos maiores para a dieta $D$ em quase todos os sub-periodos 
experimentais, para os dois sexos. A resposta mais acentuada para as fêmeas no 1 e sub-período, talvez possa ser atribuido ao consumo elevado de $143,64 \mathrm{~g} \mathrm{MS/Kg} \mathrm{PV} 0,75$ (Tabela 13 ) naque.1 a fase experimental. Como discutido anteriormente, os machos apresentaram tendência de maior sensibilidade à ação da lasalocida na fase inicial de fornecimento, e por isso, talvez o efeito do bicarbonato tenha sido menos evidente. LANNA \& BOIN (1988) não verificaram resposta de fêmeas à adição de $\mathrm{NaHCO}_{3}$ em dietas baseadas em BTPV.

Tabela 18. Efeito do sexo e dos sub-periodos experimentais sobre o ganho de peso nas dietas $B$ e $D$.

\begin{tabular}{|c|c|c|c|c|c|}
\hline \multirow{2}{*}{$\begin{array}{l}\text { Sub- } \\
\text { período }\end{array}$} & \multirow[b]{2}{*}{ Dietas } & \multicolumn{4}{|c|}{ Ganho diário em $\mathrm{kg}$} \\
\hline & & Machos & $s$ & Fêmeas & s \\
\hline 1 & $\begin{array}{l}\mathrm{B} \\
\mathrm{D}\end{array}$ & $\begin{array}{l}0,79^{x} \\
1,13^{x}\end{array}$ & $\begin{array}{l}0,16 \\
0,16\end{array}$ & $\begin{array}{l}0,60^{x} \\
1,21^{y}\end{array}$ & $\begin{array}{l}0,21 \\
Q, 21\end{array}$ \\
\hline 2 & $\begin{array}{l}B \\
D\end{array}$ & $\begin{array}{l}1,66^{x} \\
1,82^{x}\end{array}$ & $\begin{array}{l}0,16 \\
0,16\end{array}$ & $\begin{array}{l}1,34^{x} \\
1,32^{x}\end{array}$ & $\begin{array}{l}0,21 \\
0,21\end{array}$ \\
\hline 3 & $\begin{array}{l}B \\
D\end{array}$ & $\begin{array}{l}1,37^{x} \\
1,58^{x}\end{array}$ & $\begin{array}{l}0,17 \\
0,17\end{array}$ & $\begin{array}{l}1,21^{x} \\
1,39^{x}\end{array}$ & $\begin{array}{l}0,20 \\
0,20\end{array}$ \\
\hline 4 & $\begin{array}{l}B \\
D\end{array}$ & $\begin{array}{l}1,43^{x} \\
1,55^{x}\end{array}$ & $\begin{array}{l}0,22 \\
0,19\end{array}$ & $\begin{array}{l}0,66^{x} \\
1,24^{x}\end{array}$ & $\begin{array}{l}0,20 \\
\cdot, 28\end{array}$ \\
\hline 5 & $\begin{array}{l}B \\
D\end{array}$ & $\begin{array}{l}1,39^{x} \\
1,15^{x}\end{array}$ & $\begin{array}{l}0,24 \\
0,21\end{array}$ & $\begin{array}{l}1,19^{x} \\
0,61^{x}\end{array}$ & $\begin{array}{l}0,20 \\
0,29\end{array}$ \\
\hline
\end{tabular}

n.y - Ha mesma coluna mévias seguidas por letras diferentes diferem entre si $(P \leq 0,05)$.

Vale a pena ressaltar, novamente, com base nos dados apresentados na Tabela 18, os elevados ganhos de peso conseguidos no trabalho experimental. Pode-se observar que a partir lo 20 sub-periodo, onde o efeito depressivo do ionoforo era menos pronunciado, a dieta D, que possibititou 
como mencionado na Tabela 8 os maiores consumos de matéria seca, permitiu ganhos de peso diários médios de $1,82 \mathrm{k}, 1,58$ $\mathrm{kg}$ e 1,55 kg para os machos e 1,32 kg, 1,39 $\mathrm{kg} \mathrm{e} \mathrm{1,24} \mathrm{kg} \mathrm{para}$ as fêmeas.

A tendência de restrição no nível de ganho no 50 sub-período, não se justifica quando o nível de consumo é analisado na Tabela 11, nas comparaçǒes entre as dietas $B$ e D para machos e fêmeas nas diferentes fases do experimento. Comparando-se na Tabela 17 as dietas $D$ e $A$, verifica-se que a associação de bicarbonato e lasalocida, quando comparado com a dieta testemunha, não provocou efeitos significatives no ganho diário, apesar de haver tendência de ganhos maiores para todos os sub-periodos, com exceção do 5 o. Deve-se resaltar que as dietas contendo bicarbonato ( $C$ e $D$ ) foram as que possibilitaram os menores ganhos de peso no 50 sub-periodo, sendo os valeres da dieta C significativamente menores que os observados para a dieta $B$, que continha somente lasalocida. Essa ocorrencia é difícil de ser explicada, já que o nível de consumo observado (Tabe1a 8) para as dietas mencionadas no 50 sub-periodo do experimento, foi elevado, da ordem de $122,03 \mathrm{~g} \mathrm{MS/Kg} \mathrm{PV} \mathrm{MV}^{0,75}$ para a dieta $\mathrm{C}$ e $131,83 \mathrm{~g} \mathrm{MS} / \mathrm{kg} \mathrm{PV}{ }^{0,75}$ para a dieta D. Essa observação parece sugerir que a eficiência de utilização das dietas foi reduzida pela utilização de bicarbonato no final do experimento, já que os elevados consumos observados para as dietas contendo o agente tamponante não resultaram em ganho. 
Assim sendo, o bicarbonato deveria ser empregado somente no inicio do confinamento ( 56 dias) de maneira a não afetar a melhoria eserada de aumento de eficiéncia com uso da lasalocida (CHALUPA, 1980). Como o experimento foi de curta duração, na média, esse possivel efeito depressivo do bicarbonato sobre o ganho das dietas contendo lasalocida não foi observadoe, assim, uma conclusão final é dificil de ser apontada .

Considerando-se os resultados das dietas $B, C$ e o (Tabela 17) conjuntamente, pode-se verificar que a adição de $\mathrm{NaHCO}_{3}$ às dietas contendo Tasalocida possibilitou, no primeiro sub-periodo, anular o efeito negativo do ionóforo sobre o ganho de peso de animais não adaptados (SCHELLING, 1984 ) pela elevação significativa no consumo de matéria seca, como apresentada na Tabela 8 . Nos 20 e 30 sub-períodos, a ação do bicarbonato não foi tão nitida, mas no 40 houve tendência mais evidente de ganhos mais elevados, ao passo que no 50, como mencionado, houve reduçăo significativa.

Os dados sugerem que a presença do bicarbonato em dietas contendo lasalocida pode potencializar a ação do ionóforo, através de adaptação mais fácil, aumento no consumo e maior eficiência na utilizaçăo dos nutrientes no início do confinamento. BERGEN \& BATES (1984) propuseram um mecanismo de ação dos ionóforos, no qual a adição de bicarbonato poder ia anular o efeito do ionóforo, contradizendo assim os resultados obtidos. Por outro lado, RUSSELL (1987) propondo 
outro mecanismo de ação do ionóforo, relatou que o bicarbonato poderia potencializar o efeito dequele aditivo. Trabalhando com dietas à base de BTPV, SILVA (1990) verificou que o bicarbonato potencializou a ação do ionóforo no rúmen, resultando em maior produção de ácido propiônico e redução na produção de metano, fatos esses que coincidem com os resultados obtidos. Seria importante o estabelecimento de trabalhos de pesquisa para verificar se o beneficio da associação de lasalocida e bicarbonato tem curta duraçăo, como sugerido no presente trabalho, e para caracterizar a razão da perda de eficiência observada.

c) Ausência de cana-de-açúcar picada como fonte de fibra em dietas contendo lasalocida e bicarbonato.

Comparando-se na Tabela 17 as dietas $D$ e $C$, verifica-se que a retirada de cana-de-açúcar picada da dieta contendo lasalocida e bicarbonato não afetou significativamente o ganho de peso. Entretanto, deve-se atentar para o fato de que em todos os sub-periodos experimentais, com exceção do 5오, apareceu tendência de redução. Como discutido anteriormente (Tabela 8 ), a ausência da cana-de-açúcar provocou um consumo mais baixo de matéria seca, sendo o efeito notado também nos sub-periodos experimentais. Como consequencia, foi possivel caracterizar 
tendência de ganhos mais baixos do 10 ao 40 sub-periodo do experimento.

A comparą̧a entre as dietas C e A (Tabela 17). indica que no ocorreram diferenças significativas no ganho diário pela substituição da cana-de-açúcar como fonte de fibra em uma ração básica de BTPV (60\%) e concentrado (40\%), por bicarbonato de sódi e lasalocida. Com base nessa informação e considerando que não foram observados distúrbios digestivos entre os animais que não receberam cana, é possivel propor que a cana picada pode ser dispensada. Entretanto, deve-se considerar nessa proposiçăo os aumentos significativos obtidos no consumo (Tabela 8), a tendência de ganhos maiores nas dietas com cana (Tabeia 17).

\subsection{Conversão alimentar}

A análise de variância (Tabela 3 do apêndice) revelou que a variável conversão alimentar foi significativamente influenciada pelo sub-periodo e pelo sexo, ocorrendo também interação significativa entre dietas e subperiodos. A Tabela 19 mostra os valores da conversão alimentar estimado para machos e fêmeas dentro de cada sub periodo experimental. 
Tabela 19. Efeito do sexo e do sub-periodo experimental sobre o consumo de matéria seca.

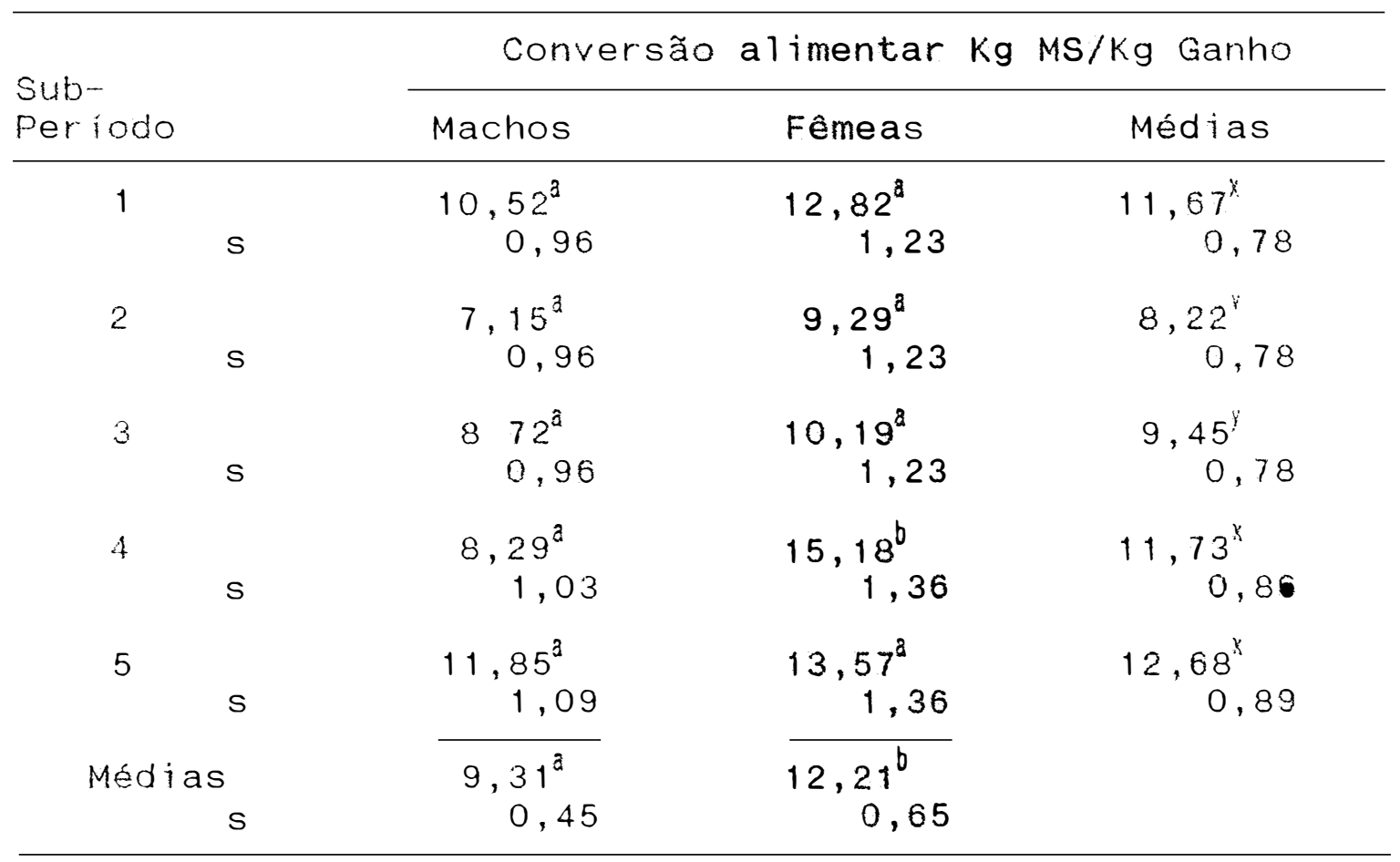

a.b - Na mesma linha médias seguidas por letras diferentes diferen entre si $(P \leq 0,05)$.

$x, x$ - lia mesma coluna médias seguidas oor latras diferentes diferen entre si $(P \leq 0,05)$.

A conversão média durante o período experimental foi de $9,31 \mathrm{Kg} \mathrm{MS} / \mathrm{Kg}$ ganho para os machos e $12,21 \mathrm{~kg} \mathrm{MS} / \mathrm{kg}$ ganho para as fémeas, valores esses significativamente diferentes. A menor eficiência das fêmeas, no que diz respeito ao aproveitamento dos nutrientes para o crescimento e engorda, é fato bem estabelecido na pesquisa (ROCHE \& QUIRKE, 1996). Trabaihando com animais semelhantes e usando rações à base de BTPV, LANNA \& BOIN (1988) também obtiveram dados mostrando a maior eficiência dos machos submetidos ao confinamento. Na análise da conversão alimentar de machos e fèmeas dentro dos sub-periodos experimentais, diferença estatitica só foi observada no 4 으 sub-periodo. 
Entretanto a tendencia geral foi de valores sempre melhores para os machos.

Os dados de conversão alimentar obtidos no presente trabalho, estão dentro do esperado para rações de engorda (NRC, 1984). Os trabalhos experimentais que utilizaram BTPV, obtiveram valores de conversăo de 6 a 14,9 $\mathrm{kg} \mathrm{NS/Kg}$ ganho (PATE, 1982; BURGI, 1985; LIMA \& ZANETTI, 1989, BERCHIELLI et a $11 i$, 1989; LACORTE, 1987; LANNA \& BOIN, 1988; NUSSIO et alii, 1990). Trabalhando com animais de mesma origem que os utilizados no presente experimento, mas bem mais jovens, LANNA \& BOIN (1988) e NUSSIO et alii (1990) obtiveram valores de conversăo alimentar variando de 6,9 a $8,8 \mathrm{~kg} \mathrm{MS} / \mathrm{Kg}$ ganho.

Verificando-se o comportamento de conversão al imentar na Tabela 19, pode-se verificar que no segundo e terceiro sub-periodos os resultados foram significativamente methores, indicando maior eficiência do uso das rações experimentais. A pior conversăo alimentar observada no 1 은 sub-periodo experimental, pode ser atribuida, ao problema já mencionado da falta de adpatação ao ionóforo (SCHELLING, 1984). A perda de eficiência detectada nos dois úttimos subperiodos, onde o valor de conversão alimentar foi significativamente elevado ( Tabela 19), poderia ser explicado pela tendência de redução no ganho de peso (Tabela 17), associada aos consumos elevados (126 a $128 \mathrm{~g} \mathrm{MS} / \mathrm{Kg} \mathrm{PV}^{0,75}$ ) de matéria seca, obtidos no presente trabalho (Tabela 8). Deve- 
se também considerar a proposta apresentada de que no inicio do experimento pode ter havido ganho compensatório, quando a eficiência é maior (VILLARES, 1978).

4.3.1. Efeito das dietas sobre a conversåo alimentar a. Efeito da lasalocida sódica

A and́lise de variância (Tabela 3 do apêndice) não mostrou efeitos significativos das dietas sobre a conversão alimentar estimada para o trabalho experimental. Pode-se verificar na Tabela 20 , que a comparaçăo entre as dietas $B$ e $A$, indicou que a adição de lasalocida sódica não afetou significativamente a conversăo alimentar dos bovinos durante o periodo experimental. Entretanto, pode-se notar claramente, eliminando-se o sub-período 1 onde ocorreu adaptação dos animais ao ionóforo, que a tendência foi da dieta $B$ apresentar melhor conversão alimentar (4,8\% melhor na média). Essa tendência é seme ihante à verificada por GOODRICH et alii (1984), que revisaram 228 ensaios envolvendo 11.274 bovinos, recebendo dietas ricas em grăos no confinamento. Os autores verificaram na média, uma melhoria de $7,5 \%$ no indice de conversão alimentar ela adição de ionoforos.

Fode-se também verificar na Tabela 20 , que no 10 sub-periodo experimental, quando os animais não estavam adaptados, a adição de lasalocida piorou significativamente a conversão alimentar (B comparada com A) em cerca de 54,2\%. 
Esse efeito do ionóforo alterando o funcionamento do rúmen e a eficiência de utilização dos alimentos foi discutida anteriormente (SCHELLING, 1984; RUSSELL \& STROBEL, 1989). Deve-se notar que, após o primeiro sub-periodo a presença do ionóforo promoveu melhorias não significativas nos indices de conversăo de $17,7 \%$ no 2 O sub-periodo, $12,6 \%$ no 3 으, 13,8 no 4 은 e $25,5 \%$ no 50 .

Tabela 20. Efeito das dietas e dos sub-periodos sobre a conversão alimentar.

\begin{tabular}{|c|c|c|c|c|c|}
\hline \multirow{2}{*}{$\begin{array}{l}\text { sub- } \\
\text { periodo }\end{array}$} & \multicolumn{3}{|c|}{ Conversão alimentar $\mathrm{kg} \mathrm{MS} / \mathrm{kg}$} & \multirow{2}{*}{$\frac{\text { ganho }}{\text { Dieta D }}$} & \multirow[b]{2}{*}{ Médias } \\
\hline & - ieta A & Dieta $B$ & Dieta C & & \\
\hline 1 & $\begin{array}{r}10,13^{8} \\
0,53\end{array}$ & $\begin{array}{r}15,62^{b} \\
1,53\end{array}$ & $\begin{array}{l}10,23^{a} \\
1,53\end{array}$ & $\begin{array}{rl}10,71^{8} & 1,53\end{array}$ & $\begin{array}{r}11,67^{x} \\
0,78\end{array}$ \\
\hline 2 & $\begin{array}{ll}9 & 09^{8} \\
& 1,53\end{array}$ & $\begin{array}{l}748^{3} \\
1,53\end{array}$ & $\begin{array}{r}8,38^{a} \\
1,53\end{array}$ & $\begin{array}{r}7,94^{\mathrm{a}} \\
1,53\end{array}$ & $\begin{array}{r}8,22^{y} \\
0,78\end{array}$ \\
\hline 3 & $\begin{array}{r}10,60^{3} \\
1,53\end{array}$ & $\begin{array}{l}9,26^{3} \\
1,53\end{array}$ & $\begin{array}{l}9,10^{\circ} \\
1,53\end{array}$ & $\begin{array}{r}8,86^{a} \\
1,53\end{array}$ & $\begin{array}{r}9,45^{y} \\
0,78\end{array}$ \\
\hline 4 & $\begin{array}{r}15,22^{\natural} \\
1,53\end{array}$ & $\begin{array}{r}13,11^{a b} \\
1,70\end{array}$ & $\begin{array}{r}9,69^{b} \\
1,53\end{array}$ & $\begin{array}{r}8,90^{b} \\
1,94\end{array}$ & $\begin{array}{r}11,73^{x} \\
0,86\end{array}$ \\
\hline 5 & $\begin{array}{r}12,29^{30} \\
1,70\end{array}$ & $\begin{array}{l}9,11^{\hat{a}} \\
1,70\end{array}$ & $\begin{array}{l}13,30^{a b} \\
1,53\end{array}$ & $\frac{16,08^{b}}{1,94}$ & $\begin{array}{r}12,68^{*} \\
0,89\end{array}$ \\
\hline $\begin{array}{r}\text { Média } \\
\text { s }\end{array}$ & $\begin{array}{l}11,47^{\mathrm{a}} \\
0,72\end{array}$ & $\begin{array}{l}10,91^{a} \\
0,74\end{array}$ & $\begin{array}{l}10,14^{2} \\
0,70\end{array}$ & $\begin{array}{c}10,50^{a} \\
0,78\end{array}$ & \\
\hline
\end{tabular}

$a, b, c$ - ha mesma linha médias seguidas oor letras diferentes diferen entre si $(\beta \leq 0,05)$. $x_{1} y$ - ha mesma coluna médias seguidas por letras diferentes diferem entre si $(P \leq 0,05)$.

Na análise da Tabela 21 verifica-se que a adição de lasalocida sódica não afetou os indices de conversão alimenar tanto em machos quanto em fêmeas ( $B$ comparada com A), apesar de se verificar também neste caso a 
tendència já mencionado de melhora. Nessa análise pode se observar um comportamento mais uniforme na conversão alimentar de machos (variando de 8,88 a 9,74) e de fêmeas (variando de 10,59 a 13,20) durante o experimento. Tabela 21. Efeito do sexo e das dietas sobre a conversão a 1 imentar.

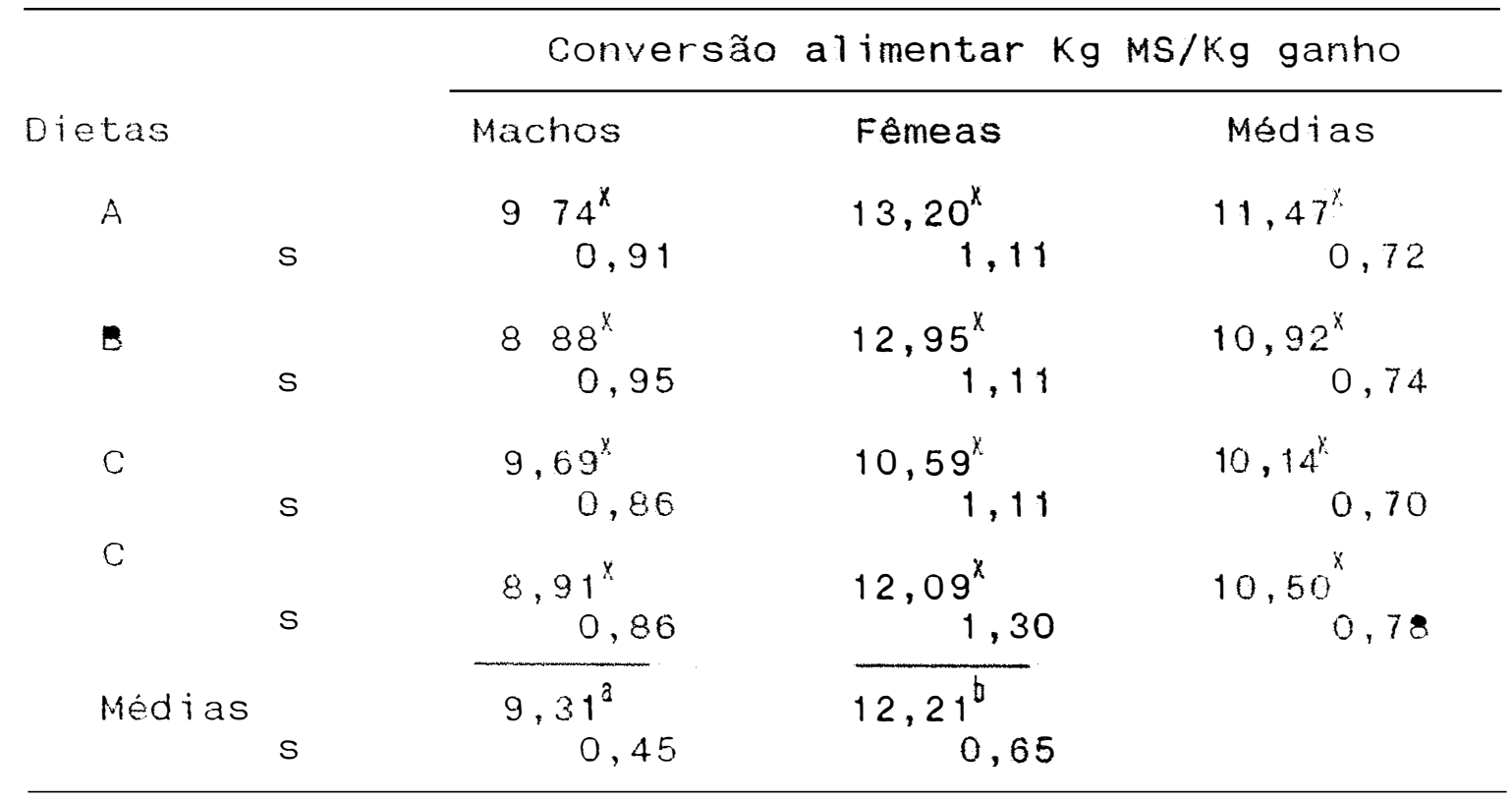

a.b.c - va mesma linha médias seguidas por letras diferentes diferem entre si $(P \leq 0,05)$.

$x, y$ - lia mesma coluna médias segudidas por letras diferentes diferen entre si $(P \leq 0,05)$

b) Adição de bicarbonato às dietas contendo Tasalocida

A anárise da Tabela 20 indica que a comparação entre as dietas $0(10,50 \mathrm{~kg}$ MS/ Kg ganho $)$ e $\mathrm{B}(10,91 \mathrm{~kg} \mathrm{MS} / \mathrm{Kg}$ ganho revela que na média, a adiçåo de $\mathrm{NaHCO}_{3}$ à dieta contendo Tasalocida năo a Tterou a conversăo a limentar durante - periodo experimental. Entretanto, a verificação do 
comportamento das dietas dentro do periodo experimental indica que a adição de bicarbonato melhorou significativamente a conversão alimentar no 10 sub-período. O efeito benéfico da adição de bicarbonato no to sub-periodo indica que o agente tamponante foi capaz de anular ou reduzir o efeito depressivo do ionóforo sobre animais não adaptados (SCHEELING, 1984), trazendo como discutido anteriormente consumos significativamente maiores de matéria seca (Tabela 8), e ganhos de peso também significativamente mais elevados (Tabela 17). Esse efeito precisa ser estudado em detalhes para a caracterizacão do efeito associativo. Analisando parametros ruminais de vacas fisturadas, SILVA (1990) detectou efieitos significativos da associaçăo dos dois aditivos alterando as produçóes estimadas de ácido propiónico e de metano.

Os dados inseridos na Tabe 1 a 20 também mostram que o efeito benéfico da adição de bicarbonato à dieta contendo lasalocida (D comparada com B) năo foi significativo no 20 e 30 sub-periodos. Essa observação está de acordo com os dados obtidos por LANNA \& BOIN (1988) que relataram vantagens da adição do $\mathrm{NaHCO}_{3}$ somente no início do período experimenta1. Não se encentrou uma explicaçăo lógica para a aparente tendência de melhora da conversão alimentar durante o 4Q sub-período, a não ser o fato de que a partir dessa fase a ração passou a ter um nivel mais elevado de lasalocida sódica (37 ppm na MS) como detectado nas análises de 
laboratório. Nos primeiros sub-periodos a quantidade detectada foi de 24,6 ppm e, assim sendo, pode aparecer de novo o efeito do agente tamponante inibindo o efeito depressivo do ionóforo.

$$
\text { Efetuando-se a comparaçăo entre as dietas } D \text { e }
$$

A, com os dados inseridos na Tabe 1 a 20 , pode-se verificar que na média, não ocorreram diferenças significativas entre a dieta testemunha (A) e auela contendo os dois aditivos empregados no experimento (D). Observa-se que em todos os sub-periodos experimentais, com exceça do 50, as dietas tiveram comportamentos idênticos, apesar de se notar tendència de melhoria para a dieta contendo lasalocida sedica e bicarbonato. Esse efeito havia sido notado para consumo de matéria seca (Tabela 8) e ganho de peso (Tabela 17).

A. comparação entre todas as dietas apresentadas na Tabela 20 mostra uma tendência aparente de superioridade para as duas dietas contendo bicarbonato. Como discutido anteriormente, essa mesma tendencia foi observada para as variáveis consumo de matéria seca e ganho de peso, indicando possiveis efeitos diretos e associativos entre os aditivos. Deve-se porém atentar para o fato de que no 50 subperíodo o desempenho do lote recebendo bicarbonato foi reduzido, aparecendo inclusive piora significativa na conversão da dieta D. Assim sendo, a proposta sugerida na discussão relativa ao ganho de peso para as dietas com bicarbonato parecem válidas. Havia sido caracterizado no 50 
sub-periodo, consumo relativamente elevado de matéria seca (Tabela 8) e tendência de ganho de peso menor, sugerindo perda de eficiência. Seria então, de grande importância, estudar o efeito prolongado do uso do bicarbonato, para caracterizar um possivel efeito depressivo, sugerido no presente trabaino.

c) Ausência de cana-de-açúcar picada como fonte de fibra em dietas contendo lasalocida e bicarbonato

A observacáo dos dados contidos na Tabela 20 , indicam năo haver diferenças significativas entre as médias das dietas $c$ e $D$, que tiveram um comportamento muito semelhante durante todo o transcorrer do experimento. Com base nesses resultados, pode-se sugerir, como feito anterformente, que a cana-de-açúcar pode ser suprimida das dietas contendo BTPV, apesar do seu efeito benéfico sobre o consumo e o ganho de peso. Deve-se também ser lembrado que não foram detectados distúrbios digestivos a nível de rúmen com a dieta sem cana-de-ąúcar.

A comparação entre as dietas A e C, sugere que a substituição de cana pelos dois aditivos utilizados resultou em tendência de redução no consumo de matéria seca (Tabela 8) e nầo afetou, de maneira geral o ganho de peso (Tabela 17) e a conversão alimentar (Tabela 20). 
5) CONCLUSÃO

Dietas contendo 50-60\% de bagaço de cana tratado sob pressão de vapor (BTPV) com base na matéria seca, possibilitam elevado consumo e ganho de peso com uma conversão alimentar satisfatória em bovinos jovens. A adição de lasalocida sódica prejudica o desempenho de bovinos não adaptados, porém quando os animais já estão adaptados parece existir methor eficiência de utilizaşăo dos alimentos. A adição de bicarbonato de sódio pode anular o efeito depressivo da lasalocida sódica sobre o consumo, o ganho de peso e a conversão alimentar de animais não adaptados ao ionoforo. A partir da adaptaçăo dos bovinos à lasalocida sódica, a adição de bicarbonato de sódio apresenta tendência em melhorar o desempenho animal, porém após 56 dias de fornecimento ele pode prejudicar o ganho de peso e a conversão alimentar. Este efeito negativo do bicarbonato de sódio precisa ser melhor estudado, através de experimento de Tonga duração. Há um efeito benéfico da associação bicarbonato de sódio e lasalocida sódica sobre o desempenho dos animais, seja devido à açăo tamponante do $\mathrm{NaHCO}_{3}$ e ou à ação da lasalocida sódica pontecializada pelo $\mathrm{NaHCO}_{3}$. Em 
dietas à base BTPV suplementadas com $\mathrm{NaHCO}_{3}$ + Tasalocida, a ausência de cana-de-açúcar não afeta a eficiência de utilização dos alimentos. O bom desempenho dos bovinos recebendo dietas sem cana-de-açúcar e a ausência de distúrbios metabúlicos, indicam que é possivel utilizar o BTPV como único alimento volumoso quando $\mathrm{NaHCO}_{3}+$ lasalocida são fornecidos. Em situações onde se pretenda estimular o consumo de matéria seca, a adição de cana-de-açúcar pode ser um recurso interessante.

o experimento conduzido não permitiu uma avaliação conclusiva sobre o efeito de adiçăo do ionóforo lasalocida, do agente tamponante bicarbonato de śodio, e da cana-de-acúcar como fonte de fibra integra em dietas à base de BTPV. 


\section{REFERENCIAS BIOLIOGRAFICAS}

ANDERSEN, M.A. \& HORN, G.W. Effects of lasalocid on weight gains, ruminal fermentation and forage intake of stocker cattle grazing winter wheat pasture. Journal of Animal science, 65(4):865-71, 1987 .

A.O.A.C. Official methods of analysis Association of official Agricultural Washington, D.C., 1965.

Chemists. Tenth edition.

A.R.C. The Nutrient Requirements of Ruminants Livestock. second edition. London, D.C., 1984.

ARMENTANO, L.E. \& SOLORZANO, L.C. Choice of buffers should depend on diet, environment. Feedstuffs, $60(3): 19-62$, 1988 .

ARMSTRONG, J.D. \& SPEARS, J.W. Intravenous administration of ionophores in ruminants: effects on metabolism independent of the rumen. Journal of Animal Science, $66(7): 1807-17,1988$.

BALDWIN, R.L. \& ALLISON, M.J. Rumen metabolism, Journat of Animal Science, $57: 461,1983$.

BENZ, D.A.; BYERS, F.M.; SCHELLING, G.T.; GREENEM L.W.; LUNT, D.K. and SMITH, S.B. Ionophores alter hepatic concentrations of intermediary carbohidrate metabolites in steers. J. Animal Science, 67(9):2393, 1989.

BERCHIELLI, T.T.; ANDRADE, P.; PINOTTI, R.F. \& KRONKA, S.N. Niveis de concentrado e uréia na alimentação de bovinos nelore com bagaço de cana hidrolisado. In: SBZ Anais da XXVI Reuniz̃o Anual da Sociedade Brasileira de Zootecnia, Porto Alegre - RS, 1989. p. 157.

BERGEN, W.G. \& YOKOYAMA, M.T. Productive Timits to rumen fermentation. Journal of Animal Science, 45(3):573-584, 1977 . 
BERGEN, G.W \& BATES, D.B. Ionophores: Their effect on production efficiency amd mode of action. Journal of Animal Science, 58(6):1465-83, 1984 .

BOERNER, B.J.; BYERS, F.M.; SCHELLING, G.T.; COPPOCK, C.E. \& GREENE, L.W. Trona and sodium bicarbonate in beef cattle diets: Effects on site and extent of digestion. Journal of Animal Science, 65(1):303-8, 1987a.

BOERNER, B.4.; BYERS, F.M.; SCHELLING, G.T.; COPPOCK, C.E. \& GREENE, L.W. Trona and sodium bicarbonate in beef cattle diets: Effects on $\mathrm{pH}$ and volatile fatty acid concentrations. Journal of Animal Science, 65(1):309-16, $1987 \mathrm{~b}$.

BoIN, C. Formulação de rações para bovinos de corte em confinamento. In: Peres, F.C. \& Marques, P.V. ed. Manual de Cálculo de Raşões de Custo Mínimo. Piracicaba, FEALQ. 1938. Cap. 141-191.

BOIN, C. Exigências nutricionais de Bovinos de corte. In: Peixoto, A.M. e outros. ed. Alimentação de Bovinos de Corte. Piracicaba, FEALQ, 1990. Cap. 257-270.

BONDI, A. Metabolism of protein in ruminant animals. A Review. Nutrition Reports International, 23(5):993, 1981 .

BRANINE, M.E., LOFGREEN, G.P.; GALYEAN, M.L.; HUBBBET, M.E.; FREEMAN, A.S. and GARCIA, D.R. Comparison of continuous with daily and weekly alternate feeding of lasalocid and monensin plus tylosin on performance of growing finishing steers. J. Animal Science, 67(sup) 2) : 206,1989 .

BRITTON, R. \& STOCK, R. ACidosis: a continual problem in cattle fed high grain diets. In: Conference for Feed Manufactures. Proceedings. Cornel1 Nutrition, Syracuse Marriott, East syracuse, N.Y., 1989. p. 8-15.

BURGI, R. Produça do bagaço de cana-de-açúcar (Saccharum sp.L.) auto-hidrolisado e avaliação do seu valor nutritivo para ruminantes. Piracicaba, 1985. 61 p. (Mestrado Escola Superior de Agricultura "Luiz de Queiroz" / USP).

BURGI, R. Utilizaçäo de resíduos agroindustriais na alimentaça de ruminantes. Congresso Brasileiro de Pastagens, 1986.

BURGI, R. O bagaço de cana-de-açúcar no confinamento de bovinos de corte. 60 Congresso Paulista de Agronomia, aposti1a, $1987,6 p$. 
BYERS, F.M.; SCHELLING, G.T. and COPPOCK, C.E. Scientist test a new buffer for ruminants. Feedstuffs, september 16, p. $18-20,1985$.

CASTRO, F.B. Avaliação do processo de digestão do bagaço de cana-de-açúcar ( Saccharum sp.L) auto-hidrolisado em bovinos. Piracicaba, 1989. 123 p. (Mestrado - Escola Superior de Agricultura "Luiz de Queiroz" / USP).

CHALUPA, W. Manipulating rumen fermentation. J. Animal Science, $46(3): 585,1377$.

CHALUPA, W. Chemical control of Rumen Microbial metabolism. In' RUCKEBUSH \& THIVEND, ed. Digestive Physiology an Metabolism in Ruminants. AVI Publishing Co., Westport, CT, 198 . p $325-347$.

CHIRASE, N.K.; GREENE, L.W.; LUNT, D.K; BAKER, J.F. \& KNUTSON; R.E. Serum and ruminal fluid characteristics of beef cows grazing oat pasture and supplemented with or without lasalocid. Journal of Animal Science, $66(7): 1746-54,1988$.

CHRISTIANSEN, M.L. \& WEBB Jr., K.E. starch and protein digestibility and amino acid absorption in beef cattle fed a high concentrate diet euith mineral acidneutralizing compounds. Virginia Iech Livestock Reaserch Report, 1987/1988, pg. 100-105.

COSTA, L.R.o. Suplementação de uréia em dietas de bagaço de cana (Saccharum s. L.) auto-hidrolisado para ruminantes. Piracicaba, 1987. $111 \mathrm{p}$. (Mestrado - Escola Superior de Agricultura "Luiz de Queiró" / USP).

COUNOTTE, G.H.M.; VAN'T KLOOSTER, A.Th,; VAN DER KUILEN, J. and PRINS, R.A. An analysis of the buffer system in the rumen of dairy cattle. J. Animal Science, 49(6):1536, 1979 .

DAWSON, K.A. \& BOLING, J.A. Effects of potassium ion concentrations on the antimicrobial activities of ionophores against ruminal anaerobes. Applied Enviromental Microbiology, 53(10):2363-67, 1987.

DELFINO, J,; MATHISON, G.W. \& SMITH, M.W. Effect of lasalocid on feedlot performance and energy partitioning in cattle. Journal of Animal science, 66(1):136-50, 1988 . 
DESWYSEN, A.G. and ELLIS, W.C. Site and extent of neutral detergent fiber digestion, effeciency of ruminal digesta flux and fecal output as related to variations in voluntary intake and chewing behavior in neifers. J. Animal Science. 66:2678, 1988.

DIVEN, R.H. Bicarbonates in Ruminants nutrition and physiology. Feedstuffs, August 4:21-26, 1975a.

DIVEN, R.W. Bicarbonates in Ruminant Nutrition and Physiology. Feedstuffs, August 11, p. 23-25, $1975 \mathrm{~b}$.

FRANCISCO Jr., J.C.; MACHADO, P.F. Efeito da uréia sobre a atividade fermentativa do rúmen e degradação de bagaço auto-hidrolisado. Anais da 27a Reuniăo Anual da Sociedade Brasileira de Zootecnia, Campinas, SP, Brasi1, 1990 .

FUNK, M.A.; GALYEAN, M.L. and ROSS, T.T. Motassium and lasalocid effects on performance and digestrion in 1ambs. J Animal Science, 63:685, 1986.

GOERING, H.K. \& VAN SOEST, P.J. Forage fiber analyses (Apparatus reagents, procedures and some applications). Washington, D.C. Agricultural Research Service, USDA. 19 p. A riculure Handbook, p. 379, 1970.

GOODRICH, R.D.GARRETT, J.E.; GAST, D.R.; KIRICK, M.A.; LARSON, D.A. \& MEISKE, J.C. Influence of monensin on the performance of cattle. Journal of Animal science, $58(6): 1484-98,1984$.

HAALAND, G.L. \& TYRRELL, H.F. Effects of limestone and sodium bicarbonate buffers on rumen measurements and rate of passage in cattle. Journal of Animal Science, $55(4): 935-42,1982$.

HAALAIND, G.L.; TYRREL, H.F.; MOE, P.W. \& WHEELER, W.E. Effect of crude protein level and limestone buffer in diets fed at two levels of intake on rumen $\mathrm{pH}$, ammonianitrogen, buffering capacity and volatile fatty acid concentration of cattle. Journal of Animal Science, $55(4): 943-50,1982$.

HINKLE, P.C. and MCCARTY, E. How cells make ATP. In: molecules to living cells. W.H. Freeman and Company, San Francisco, California, USA. p. 154-169, 1980.

HESPELL, R.B. and BRYANT, M.P. Efficiency of rumen microbial growth: Influence of some therethical and experimental factor on y ATP. J. Animal Science, $43(6): 1640,1979$. 
JACQUES, K.A.; AXE, D.E.; HARRIS, T.R.; HARMON, D.L.; BOLSEN, K.K. \& JOHNSON, D.E. Effect of sodium bicarbonate and sodium bentomite on digestion, solid and liquid flow, and ruminal fermentation characteristics of forage sorghum silage-based diets fed to steers. Journal of Animal Science, 63( ):923-32, 1986.

JAMES, L.G. \& WOHLT, J.E. Effect of supplementing equivalent cation amounts from $\mathrm{NaCl}, \mathrm{MgO}, \mathrm{NaHCO}_{3}$ e $\mathrm{CaCO}_{3}$ on nutrient utilization and acid-base status of growing dorset lamles fed high concentrate diets. Journal of Animal Science, 60(1):307-15, 1985 .

KOVACIK, A.M.; LOERCH, S.C. \& DEHORITY, B.A. Effect of supplemental sodium bicarbonate on nutrient digestibilities and ruminal pH measured continuously. Journal of Animal Science, 62:226-34, 1986.

KRONFELD, D.S. Sodium, osmolarim and nydration. Rigulation of Acid-Base balance. Chuich J night Co, Inc. Ed. W.H. Hale and Paul Meinhaidt, 1978.

LACORTE, M.C.F. Desempenho de bovinos confinados à base de bagaço de cana-de-açúcar auto-hidrolisado, levedura e vinhaça, subprodutos da indústria de açúcar e á1cool. Piracicaba, 1987. 71p. (Mestrado - Escola Superior de Agricultura "Luiz de Queiroz" / USP).

LANNA, D.P.D. \& BOIN, C. Efeito da adição de bicabonato de sódio, feno e bagaço de cana-de-açúcar "In Natura" em dietas à base de bagaço hidrolisado, 1988. (A ser publicado nos Anais da E.S.A. Luiz de Queiroz).

LIMA, M.L.P. \& ZANETTI, M.A. Utilização do bagaço hidrolisado como alimento volumoso para bovinos confinalos. In: SBZ. Anais da XXVI Reunião Anual da Sociedade Brasileira de Zootecnia, Porto Alegre, RS, 1989. p. 156.

MACHADO, P.F. \& MADEIRA, H.M.F. Manipulação de Nutrientes em nivel de rúmen - efeitos do uso de ionóforos. In: Novas Técnologias de Produção Animal, SBZ, Campinas SP, 1990. p. $41-58$.

MATTOS, W.R.S. Utilização do bagaço de cana-de-açúcar na a 7 imentação de ruminantes. In: D'ARCE, R.D.; BOIN, C. \& MATTOS, W.R.S. Utilizą̧ão de residuos agro-industriais da cana-de-açucar na alimentação de ruminantes. Piracicaba - SP, FEALQ, 1985. p. 53-72. 
NAGARAJA, T.G.; AVERY, T.B.; BARTLEY, E.E.; GALITZER, S.J. \& DAYTON, A.D. Prevention of lactic acidoses in cattle by lasalocid or monensin. Journal of Animal Science, $53(1): 206-15,1981$.

NAGARAJA, T.G.; AVERY, T.B.; BARTLEY, E.E.; ROOF, S.K. \& DAYTON, A.D. Effect of lasalocid, monensin or thiopeptin on lactic acidosis in cattle. Jounal of Animal science, 54(3):649-58, 1982 .

N.R.C. Commite on Animal Nutrition. Nutrient requirements of beef cattle. Sixth edition. Washington, D.C., 1984.

NUSSIO, L.G.; SILVA, S.C.; BOIN, C. e SANTOS, F.A.P. Avaliação do uso de bicarbonato de sódio em dietas com bagaço de cana auto-hidrol isado no desempenho de bovinos confinados. XXVII Reuniăo Anual da Sociedade Brasileira de Zootecnia, Campinas, SP. 1990.

OKEKE, G.C.; BUCHANAN-SMITH, J.G.. \& GROVUM, W.L. Effects of buffers on ruminal rate of passage and degradation of soyban meal in steers. Journal of Animal science. $56(6): 1393-99,1983$.

OWENS, F.N. e GOETSCH, A.L. Digesta passage and microbial protein synthesis. In: Sixth International symposium on Ruminant Physiology, Canadá. Proceedings, 1984.

PATE, F.M. Value of treating bagasse with steam under pressure for cattle fed. Tropical Agriculture, $59(4): 293-7,1982$.

PATERSON, J.A.; ANDERSON, B.M.; BOWMAN, D.K.; MORRISON, R.L. and WILLIANS, J.E. Effect of protein source and Lasalocid on $N$ digestibility and growth by ruminants. J. Animal science, $57(6): 1537,1983$.

PEIRCE, S.B.; MULLER, L.D. \& HARPSTER, H.W. Influence of sodium bicarbonate and magnesium oxide on digestion and metabolism in yearling beef abruptiy changed from high forage to high energy diets. Journal of Animal Science, $56(6): 1561-7,1983$.

PLANO CONSULTORIA AGROPECUARIA. ReTatórios Ténicos Finais de Confinamentos comerciais, 1989.

PLANO CONSULTORIA AGROPECUÁRIA. (1990). Comunicação pessoal. PREÇOS AGRICOLAS. Piracicaba (38): 140, dez. 1989.

PRESSMAN, B.C. Biological application of ionophores. Animal Review of Biochemistry, 45:501, 1976. 
RICKE, S.C.; BERGER, L.L.; VAN DER AAR \& FAHEY Jr, G.C. Effects of lasalocid and monensin on nutrients digestion, metabolism and rumen characteristics of sheep. Journal of Animal Science, 58(1):194-202, 1984.

ROBY, K.A.W.; CHALUPA, W.; ORSINI, J.A.; ELSER, A.H. \& KRONFELD, D.S. Acid-base and electrolyte balance in dairy heifers fed forage and concentrate rations: Effects of sodium bicarbonate. Am. J. Vet. Res., $48(6): 1012-16,1987$.

ROCKE, J.F. \& QUIRKE, J.F. The Effects of steroid Hormones and Xenobiotics on growth of in animals. Control and manipulation of animal growth, p. 39, 1986.

RUAS, D.G.G., Utilização do bagaço por usinas e destil arias da Região centro-sul. Rev. Alcool e Açúcar no 50, 1989.

RUMPLER, W.V; JOHNSON, D.E. \& BATES, D.B. The effect of high dietary cation concentration on methanogenesis by steers fed diets with and without ionophores. Journal of Anlinal Science, 62(6):1737-41, 1986.

RUSSELL, J.R.; YOUNG, A.W. \& JORGENSEN, N.A. Effect of s-dium bicarbonate and 1 imestone additions to high grain diets on feedlot performance and ruminal and feca parameters in finishing steers. Journal of Animal science, 51(4):996-1002, 1980.

RUSSELL, J.B. A proposed mechanism of monensin action in inhibiting ruminal bacterial growth: effects on ion fluxo and protonmotive force. Journal of Animal Science, $64(5): 1519-25,1987$.

RUSSELL, J.B. \& STROBEL, H.J. Effect of ionophores on ruminal fermentation. Applied and Environmental Microbiology, 55(1):1-6, 1989.

SAS Institute Inc. SAS/STAT User's Guide ed. Cary, NC, 1988 .

SCHELLING, G.T. Monensin mode of action in the rumen. Journal of Animal Science, 58(6)-1518-1527, 1984.

SILVEIRA, A.C. \& DOMINGUES, C.A. Sistemas de Alimentação de novithas em crescimento. Anais do 30 simpósio sobre Manejo de Bovinos no Trópico, Botucatu, S.P., 1978, p. 134.

SPEARS, J.W. \& HARVEY, R.W. Performance, ruminal and serum characteristics of steers fed lasalocid on pasture. Journal of Animal Science, 58(2):460-4, 1984. 
SPEARS, J.W. and HARVEY, R.W. Lasalocid and dietary sodium and potassium effects on mineral metabolism ruminal volatile fatty acids and perfomance of finishing steers. J Animal Science, 65:830, 1987.

SPROTT, L.R.; GOEHRING, T.B.; BEVERLY, J.R. and COPRAH, L.R. Effects of ionophores on cow herd production: a Review. J. Animal Science, 66:1340, 1988.

STABEL, J.R.; SPEARS, J.W., HARVEY, R.W. and LUCAS, D.M. Salinomyan and lasalocid effects on growth rate, mineral metabolism and ruminal fermentation in steers.

J. Animal scince, 67:2735, 1989.

STAPLES, C.R. \& LOUGH, D.S. Efficacy of supplemental dietary neutralizing agents for lactating dairy cows. A review. Animal Feed Science and Technology, 277-303, 1989.

STARNES, S.R.; SPEARS, J.W.; FROETSCHEL, M.A. \& CROOM Jr., W.J. Influence of monensin and lasalocid on mineral metsholism and ruminal urease activity in steers. The Journal of Nutrition, 114(3):518-25, 1984.

STROBEL, H.J.; CHOW, J.M. \& RUSSELL, J.B. Rumina1 ionophores: Manipulating fermentation and control of acidosis. In: Conference for Feed Manufactures. Proceedings Cornel1 Nutrition, Syracuse Marriott,. East Syracuse, N.Y., 1989. p. 16-21.

STROUD, T.E.; WILLIAN, J.E.; LEDOREX, D.R. and PATERSON, J.A. The infiuency of sodium bicarbonate and dehydrated alfafa as buffers on steer performance and ruminal characteristics. J. Animal science, 60(2):551, 1985.

TAMMINGA, S. Protein Degradation in the forestomachs of ruminants. J. Animal Science, 49(6):1615, 1979.

TEH, T.H.; HEMKEN, R.W. \& HARMON, R.J. Comparasions of buffers and their modes in the rumen and abomassum. Nutritional Reports International, 32(6):1339-48, 1985.

TEH, T.H; HEMKEN, R.W.; BRESSEL, D.R. and HARMON, R.I. comparison of buffers on rumen functions, turnover rate and gastric secretions in holstein steers. Animal Feed Science and Technology, 17:257-290, 1987.

THONNEY, M.L; HEIDE, E.K.; DUHAIME, D.J.; HAND, R.J. \& PEROSIO, D.J. Growth, feed afficiency and metabolite concentrations of cattle fed high forage diets with lasalocid or monensin supplements. Journal of Animal science, $52(2): 427-33,1981$. 
TILLEY, J.M.A. \& TERRY, R.A. A two stage techinique for the "in vitro" digestion of forage crops. Journal Brit. Grass1. Soc., 18:104-11, 1963.

VILLARES, J.B. Exploração do ganho compensatório para a produção de bovinos no trópico. Anais do 30 simpósio Sobre Manejo de Bovinos no Trópico, Botucatu, S.P., 1978, p. 249.

WHEELER, W.E. Gastrointestinal tract pH environment and the influence of buffering materials on the performance of ruminants. Journal of Animal Science, 51(1):224-35, 1980 .

WHELLER, W.E.; NOLLER, C.H. \& WHITE, J.L. Comparasion betwen 1 imistones and cement kiln dusts of similar rates of reactivity used in high concentrate diets for beef steers. Journal of Animal Science, 52(4):873-81, $1981 \mathrm{a}$.

WHEELER, W.E.; NOLLER, C.H.; WHITE, J.L. Effect of level of calcium and sodium bicarbonate in high concentrate diets on performance and nutriente utilization by beef steers. Journal of Animal Science, 53(2):499-514, $1981 \mathrm{~b}$.

YOKOYAMA, M.T. \& JOHNSON, K.A. Microbiology of the rumen and lower intestine. Michigan - State University. 1985. 
Apêndice 
Tabela 1. Análise de variancia para consumo de matéria seca $\left(\mathrm{g} / \mathrm{kg} \mathrm{PV} \mathrm{P}^{0, i 5}\right)$.

\begin{tabular}{lccccc}
\hline Causa da variação & $\begin{array}{c}\text { Graus } \\
\text { liberdade }\end{array}$ & $\begin{array}{c}\text { Soma dos } \\
\text { quadrados }\end{array}$ & $\begin{array}{c}\text { Quadrado } \\
\text { Médio }\end{array}$ & $F$ & Pr > F \\
\hline BLOCO & 2 & 866,807 & 433,403 & 14,7 & 0,0001 \\
SUB-PERIODO (P) & 4 & 2157,064 & 539,266 & 18,29 & 0,0001 \\
OIETA (D) & 3 & 1554,819 & 518,273 & 17,58 & 0,0001 \\
SEXO (S) & 1 & 2309,935 & 2309,935 & 78,36 & 0,0001 \\
DXS & 3 & 36,217 & 12,072 & 0,41 & 0,7468 \\
PXD & 12 & 264,777 & 22,064 & 0,75 & 0,6983 \\
PXS & 4 & 93,807 & 23,451 & 0,80 & 0,5334 \\
PXDXS & 12 & 267,275 & 22,272 & 0,76 & 0,6916 \\
\hline RESIDUO & 53 & 1562,414 & 29,479 & & \\
\hline TOTAL & 94 & 9337,620 & & & \\
\hline
\end{tabular}

c.V. $=4,128 \%$ 
Tabela 2. Análise de variância para ganho de peso ( $\mathrm{kg} / \mathrm{cab} / \mathrm{dia})$.

\begin{tabular}{lccccc}
\hline Causa da Variação & $\begin{array}{c}\text { Graus } \\
\text { de }\end{array}$ & $\begin{array}{c}\text { Soma dos } \\
\text { quadrados }\end{array}$ & $\begin{array}{c}\text { Quadrado } \\
\text { Médio }\end{array}$ & $F$ & $P r>F$ \\
\hline BLOCO & 2 & 0,0852 & 0,0426 & 0,27 & 0,7639 \\
SUB PERIODO (P) & 4 & 4,5120 & 1,1280 & 7,14 & 0,0001 \\
OIETA ( $)$ & 3 & 0,5793 & 0,1931 & 1,22 & 0,3039 \\
SEXO (S) & 1 & 1,1350 & 1,1350 & 7,18 & 0,0082 \\
DXS & 3 & 0,1170 & 0,0390 & 0,25 & 0,8634 \\
PXD & 12 & 3,3714 & 0,2809 & 1,78 & 0,0568 \\
PXS & 4 & 1,1752 & 0,2938 & 1,86 & 0,1207 \\
PXOXS & 12 & 1,4130 & 0,1177 & 0,75 & 0,7054 \\
PESO INICIAL & 1 & 0,0003 & 0,0003 & 0,00 & 0,9647 \\
\hline RESIDUO & 147 & 23,2332 & 0,1580 & & \\
\hline TOTAL & 189 & 40,2691 & & & \\
\hline
\end{tabular}

c.V. $=32,844 \%$ 
Tabela 3. Análise de variância para conversão alimentar.

\begin{tabular}{lcrrrr}
\hline Causa da Variação & $\begin{array}{c}\text { Graus } \\
\text { de liberdade }\end{array}$ & $\begin{array}{c}\text { Soma dos } \\
\text { quadrados }\end{array}$ & $\begin{array}{c}\text { Quadrado } \\
\text { Médio }\end{array}$ & $F$ & Pr $>F$ \\
\hline BLOCO & 2 & 20,4635 & 10,2317 & 0,92 & 0,4060 \\
SUB-PERIODO (P) & 4 & 242,0762 & 60,5190 & 5,42 & 0,0010 \\
OIETA (D) & 3 & 22,6575 & 7,5525 & 0,68 & 0,5701 \\
SEXO (S) & 1 & 159,8770 & 159,8770 & 14,33 & 0,0004 \\
OXS & 3 & 33,5013 & 11,1671 & 1,00 & 0,3998 \\
PXD & 12 & 286,4233 & 23,8686 & 2,14 & 0,0295 \\
PXS & 4 & 83,1303 & 20,7825 & 1,86 & 0,1307 \\
PXDXS & 12 & 158,6378 & 13,2198 & 1,18 & 0,3180 \\
\hline RESTDUO & 53 & 591,4403 & 11,1592 & & \\
\hline TOTAL & 94 & 1541,3063 & & & \\
\hline
\end{tabular}

C.V. $=32,77 \%$ 
Tabela 4. Planilha de dados usados para a análise de consumo (CPM) e conversão alimentar (CA),

\begin{tabular}{|c|c|c|c|c|c|c|c|c|c|}
\hline Bloco & Periodo & $\begin{array}{l}\text { Die- } \\
\text { ta }\end{array}$ & Sexo & $\begin{array}{l}\text { Cons } \\
\mathrm{Kg} \mathrm{MS}\end{array}$ & $\begin{array}{c}\text { GPDm } \\
\mathrm{Kg}\end{array}$ & $C A$ & $\begin{array}{c}\text { CPV } \\
*\end{array}$ & $\begin{array}{l}C P M \\
g / K g \\
P V^{0.75}\end{array}$ & $\begin{array}{r}\mathrm{PVm} \\
\mathrm{Kg}\end{array}$ \\
\hline b1 & p1 & $A$ & M & 10,37 & 1,36 & 7,62 & 2,93 & 127,20 & 353,50 \\
\hline b1 & $p 1$ & B & $M$ & 9,76 & 0,61 & 16,00 & 2,79 & 120,55 & 350,25 \\
\hline bl & $p 1$ & C & $M$ & 10,62 & 0,89 & 11,93 & 3,01 & 130,47 & 352,75 \\
\hline b1 & $\mathrm{p} 1$ & D & $M$ & 11,14 & 1,43 & 7,79 & 3,12 & 135,64 & 357,00 \\
\hline b1 & p2 & $A$ & $M$ & 10,87 & 1,53 & 7,10 & 2,91 & 127,88 & 373,75 \\
\hline b1 & p2 & B & $M$ & 10,33 & 1,89 & 5,46 & 2,81 & 123,01 & $36 T, 75$ \\
\hline b1 & $\mathrm{p} 2$ & C & $M$ & 10,46 & 1,36 & 7,69 & 2,84 & 124,37 & 368,50 \\
\hline b1 & p2 & D & $M$ & 12,60 & 1,75 & 7,20 & 3,32 & 146,61 & 379,25 \\
\hline b1 & p3 & $A$ & $M$ & 11,06 & 1,14 & 9,70 & 2,82 & 125,42 & 392,50 \\
\hline b1 & p3 & B & $M$ & 11,33 & 1,11 & 10,20 & 2,91 & 129,41 & 388,75 \\
\hline by & p3 & C & M & 10,39 & 1,00 & 10,39 & 2,70 & 119,54 & 385,00 \\
\hline 61 & p3 & D & M & 12,88 & 1,68 & 7,67 & 3,19 & 143,13 & 403,25 \\
\hline b1 & p4 & A & M & 10,47 & 1,39 & 7,53 & 2,55 & 114,86 & 410,25 \\
\hline b1 & p4 & B & $M$ & 10,81 & 1,46 & 7,40 & 2,66 & 119,35 & 406,75 \\
\hline b1 & p4 & C & $M$ & 10,31 & 1,10 & 9,37 & 2,58 & 115,32 & 399,75 \\
\hline b1 & p4 & 0 & $M$ & 11,91 & 1,25 & 9,53 & 2,81 & 127,52 & 423,75 \\
\hline$b 1$ & p5 & A & $\mathrm{M}$ & 11,00 & 0,70 & 15,71 & 2,60 & 117,83 & 423,50 \\
\hline$b 1$ & p5 & B & $M$ & 11,10 & 1,40 & 7,93 & 2,62 & 118,80 & 424,00 \\
\hline bi & p5 & $\mathrm{C}$ & $M$ & 10,22 & 0,90 & 11,35 & 2,48 & 111,76 & 412,00 \\
\hline$b 1$ & p5 & D & $M$ & 11,52 & 1,50 & 7,68 & 2,62 & 119,91 & 440,00 \\
\hline bi & p1 & A & $\mathrm{F}$ & 10,66 & 0,89 & 11,98 & 3,34 & 141,31 & 318,75 \\
\hline b1 & $p 1$ & B & $\mathrm{F}$ & 9,64 & 0,46 & 20,96 & 3,04 & 128,39 & 316,75 \\
\hline b1 & $\mathrm{p} 1$ & C & $\mathrm{F}$ & 9,67 & 0,82 & 11,79 & 3,01 & 127,29 & 321,75 \\
\hline b1 & p 1 & D & $F$ & 10,34 & 1,18 & 8,76 & 3,22 & 136,27 & 321,25 \\
\hline b1 & $\mathrm{p} 2$ & A & $\mathrm{F}$ & 11,54 & 1,32 & 8,74 & 3,45 & 147,62 & 334,25 \\
\hline b1 & $\mathrm{p} 2$ & B & $\mathrm{F}$ & 10,86 & 1,25 & 8,69 & 3,30 & 140,66 & 328,75 \\
\hline b) 1 & p2 & C & $\mathrm{F}$ & 10,16 & 1,00 & 10,16 & 3,04 & 129,90 & 334,50 \\
\hline bi & p2 & D & $\mathrm{F}$ & 11,25 & 1,36 & 8,27 & 3,32 & 142,40 & 339,00 \\
\hline b1 & p3 & A & $\mathrm{F}$ & 11,52 & 1,21 & 9,52 & 3,27 & 141,76 & 352,00 \\
\hline b1 & p3 & B & $F$ & 11,49 & 1,46 & 7,87 & 3,30 & 142,68 & 347,75 \\
\hline b1 & p 3 & C & $F$ & 10,80 & 1,36 & 7,94 & 3,08 & 133,18 & 351,00 \\
\hline b1 & p3 & D & $\mathrm{F}$ & 11,75 & 1,68 & 6,99 & 3,26 & 142,10 & 360,25 \\
\hline b1 & $\mathrm{p} 4$ & A & $\mathrm{F}$ & 10,83 & 0,36 & 30,10 & 2,98 & 130,23 & 363,00 \\
\hline b1 & p4 & B & $\mathrm{F}$ & 10,68 & 0,82 & 13,02 & 2,94 & 128,22 & 363,75 \\
\hline$b_{1}$ & $\mathrm{p} 4$ & c & $F$ & 9,72 & 0,82 & 11,85 & 2,65 & 116,10 & 366,25 \\
\hline b1 & p4 & 0 & $F$ & & $P$ a $r$ & $c e 1 a$ & Pe & $r d i d$ & a \\
\hline b1 & p5 & $A$ & $\mathrm{~F}$ & 11,26 & 1,85 & 6,09 & 3,00 & 132,20 & 374,75 \\
\hline b1 & p5 & B & $\mathrm{F}$ & 10,80 & 0,90 & 12,00 & 2,89 & 126,99 & 374,00 \\
\hline b1 & p5 & $c$ & $\mathrm{~F}$ & 10,10 & 1,10 & 9,18 & 2,68 & 117,93 & 377,50 \\
\hline by & p5 & D & $\mathrm{F}$ & & $P$ a $r$ & $c e 1 a$ & Pe & $r d i d$ & a \\
\hline$b_{2}$ & $\mathrm{p} 1$ & A & $M$ & 10,79 & 1,57 & 6,87 & 3,39 & 143,29 & 318,00 \\
\hline b2 & p 1 & B & $M$ & 8,33 & 1,04 & 8,00 & 2,63 & 110,94 & 316,75 \\
\hline$b_{2}$ & $p 1$ & C & $M$ & 10,07 & 1,18 & 8,53 & 3,18 & 134,28 & 316,25 \\
\hline b2 & pi & D & $M$ & 9,31 & 0,64 & 14,55 & 2,98 & 125,41 & 312,00 \\
\hline
\end{tabular}




\begin{tabular}{|c|c|c|c|c|c|c|c|c|c|}
\hline B 1000 & Periodo & $\begin{array}{l}\text { Die- } \\
\text { ta }\end{array}$ & $S e \times 0$ & $\begin{array}{l}\text { Cons } \\
\mathrm{Kg} \mathrm{MS}\end{array}$ & $\begin{array}{c}\text { GPOm } \\
\mathrm{Kg}\end{array}$ & $C A$ & $\begin{array}{c}\text { CPV } \\
\%\end{array}$ & $\begin{array}{c}C P M \\
g / K g \\
P V^{0,75}\end{array}$ & $\begin{array}{r}P \vee m \\
K g\end{array}$ \\
\hline b2 & p2 & A & M & 10,94 & 1,61 & 6,79 & 3,22 & 138,09 & 340,25 \\
\hline b2 & $\mathrm{p} 2$ & $B$ & M & 9,25 & 1,29 & 7,17 & 2,78 & 118,66 & 333,00 \\
\hline b2 & $\mathrm{p} 2$ & C & M & 10,38 & 1,78 & 5,83 & 3,09 & 132,19 & 336,25 \\
\hline b2 & p2 & D & $M$ & 10,24 & 1,68 & 6,09 & 3,12 & 132,78 & 328,25 \\
\hline b2 & p3 & A & $M$ & 11,17 & 1,36 & 8,21 & 3,09 & 134,87 & 361,00 \\
\hline b2 & p3 & B & $M$ & 10,02 & 1,71 & 5,86 & 2,83 & 122,78 & 354,00 \\
\hline b2 & p3 & C & $M$ & 10,74 & 1,68 & 6,39 & 2,97 & 129,61 & 361,25 \\
\hline b2 & p3 & D & $M$ & 11,23 & 1,25 & 8,98 & 3,22 & 139,15 & 348,75 \\
\hline$b 2$ & p4 & A & M & 10,90 & 1,04 & 10,48 & 2,89 & 127,21 & 377,75 \\
\hline b2 & $\mathrm{p} 4$ & B & $M$ & 10,17 & 1,32 & 7,70 & 2,71 & 119,28 & 375,25 \\
\hline b2 & p4 & C & $M$ & 10,26 & 1,18 & 8,69 & 2,69 & 118,92 & 381,25 \\
\hline b2 & p4 & D & M & 10,25 & 1,53 & 6,70 & 2,78 & 121,93 & 368,25 \\
\hline b2 & p5 & A & M & 10,93 & 1,35 & 8,10 & 2,79 & 124,13 & 391,75 \\
\hline b2 & p5 & B & M & 9,90 & 1,30 & 7,61 & 2,53 & 112,59 & 391,00 \\
\hline b2 & p5 & C & M & 9,96 & 0,55 & 18,10 & 2,54 & 113,00 & 392,25 \\
\hline b2 & p5 & D & M & 10,70 & 1,15 & 9,30 & 2,78 & 123,17 & 384,75 \\
\hline b2 & $p 1$ & A & $\mathrm{F}$ & 9,73 & 0,93 & 10,46 & 3,35 & 138,28 & 290,50 \\
\hline b2 & $p 1$ & B & $\mathrm{F}$ & 9,84 & 0,68 & 14,47 & 3,39 & 139,93 & 290,25 \\
\hline b2 & $\mathrm{p} 1$ & C & $\mathrm{F}$ & 9,78 & 1,11 & 8,81 & 3,34 & 138,19 & 292,75 \\
\hline b2 & p1 & D & $\mathrm{F}$ & 10,28 & 0,86 & 11,95 & 3,53 & 145,91 & 291,00 \\
\hline$b 2$ & $\mathrm{p} 2$ & A & $\mathrm{F}$ & 10,41 & 1,11 & 9,38 & 3,42 & 142,72 & 304,75 \\
\hline b2 & p2 & $B$ & $\mathrm{~F}$ & 10,17 & 1,36 & 7,48 & 3,34 & 139,52 & 304,50 \\
\hline b2 & p2 & C & $\mathrm{F}$ & 10,69 & 1,21 & 8,83 & 3,46 & 145,05 & 309,00 \\
\hline b2 & p2 & D & $\mathrm{F}$ & 11,37 & 1,21 & 9,40 & 3,72 & 155,60 & $305^{\circ}, 50$ \\
\hline b2 & p3 & A & $F$ & 10,67 & 0,86 & 12,41 & 3,35 & 141,52 & 318,50 \\
\hline b2 & p3 & $B$ & $\mathrm{~F}$ & 9,74 & 0,89 & 10,94 & 3,04 & 128,66 & 320,25 \\
\hline b2 & p3 & C & $\mathrm{F}$ & 11,45 & 1,03 & 11,12 & 3,53 & 149,67 & 324,75 \\
\hline b2 & p3 & D & $\mathrm{F}$ & 11,68 & 1,03 & 11,34 & 3,64 & 153,93 & 321,25 \\
\hline b2 & $\mathrm{p} 4$ & A & $\mathrm{F}$ & 10,63 & 0,93 & 11,43 & 3,21 & 136,98 & 331,00 \\
\hline b2 & $\mathrm{p} 4$ & B & $F$ & 9,73 & 0,43 & 22,63 & 2,95 & 125,81 & 329,50 \\
\hline b2 & $\mathrm{p} 4$ & C & $\mathrm{F}$ & 10,33 & 1,03 & 10,03 & 3,04 & 130,68 & 339,25 \\
\hline$b_{2}$ & $\mathrm{p} 4$ & D & $\mathrm{F}$ & 11,00 & 1,18 & 9,32 & 3,27 & 139,93 & 336,75 \\
\hline b2 & p5 & A & $\mathrm{F}$ & 10,55 & 0,60 & 17,58 & 3,10 & 133,10 & 340,50 \\
\hline b2 & p5 & B & $\mathrm{F}$ & 10,10 & 1,40 & 7,21 & 2,97 & 127,70 & 339,50 \\
\hline b2 & p5 & C & $F$ & 10,74 & 0,90 & 11,93 & 3,06 & 132,44 & 351,00 \\
\hline b2 & p5 & D & $F$ & 11,18 & 0,55 & 20,33 & 3,21 & 138,83 & $34 T, 75$ \\
\hline b3 & pl & A & $M$ & 12,96 & 1,14 & 11,37 & 3,19 & 143,29 & 406,00 \\
\hline b3 & $p 1$ & $B$ & $M$ & 11,47 & 0,75 & 15,30 & 2,87 & 128,30 & 399,75 \\
\hline b3 & $p 1$ & $c$ & $M$ & 12,47 & 1,43 & 8,72 & 3,09 & 138,38 & 404,00 \\
\hline b3 & $\mathrm{p} 1$ & 0 & M & 12,67 & 1,32 & 9,60 & 3,19 & 142,26 & 397,75 \\
\hline b3 & p2 & A & $M$ & 12,57 & 1,03 & 12,20 & 2,98 & 135,19 & 421,25 \\
\hline b3 & $\mathrm{p} 2$ & $B$ & $M$ & 12,23 & 1,82 & 6,72 & 2,93 & 132,35 & 417,75 \\
\hline b3 & p2 & $\mathrm{C}$ & $M$ & 12,23 & 1,75 & 6,99 & 2,87 & 130,37 & 426,25 \\
\hline b3 & $p_{2}$ & D & $M$ & 13,41 & 2,03 & 6,60 & 3,18 & 144,22 & 421,25 \\
\hline b3 & p3 & A & $M$ & 12,80 & 1,11 & 11,53 & 2,93 & 134,09 & 436,25 \\
\hline b3 & p3 & B & M & 12,94 & 1,28 & 10,03 & 2,94 & 134,81 & 439,50 \\
\hline b3 & p3 & C & $M$ & 13,08 & 1,64 & 7,97 & 2,91 & 133,87 & 450,00 \\
\hline
\end{tabular}




\begin{tabular}{|c|c|c|c|c|c|c|c|c|c|}
\hline Bloco & Periodo & $\begin{array}{l}\text { Die- } \\
\text { ta }\end{array}$ & Sexo & $\begin{array}{l}\text { Cons } \\
\mathrm{Kg} \mathrm{MS}\end{array}$ & $\begin{array}{c}\text { GPDm } \\
\mathrm{Kg}\end{array}$ & $\mathrm{CA}$ & $\begin{array}{c}\text { CPV } \\
\approx\end{array}$ & $\begin{array}{c}C P M \\
g / K g \\
P V^{0,75}\end{array}$ & $\begin{array}{r}\mathrm{PVm} \\
\mathrm{Kg}\end{array}$ \\
\hline b3 & p3 & [) & M & 14,08 & 1,82 & 7,74 & 3,14 & 144,53 & 448,25 \\
\hline b3 & p4 & A & $M$ & 12,49 & 1,28 & 9,76 & 2,76 & 127,20 & 453,00 \\
\hline b3 3 & p4 & B & M & & $P$ a $r$ & $c$ e 1 a & P e & $r d i d$ & a \\
\hline b. 3 & p4 & C & $M$ & 12,80 & 2,14 & 5,98 & 2,69 & 125,51 & 476,50 \\
\hline b.3 & p4 & D & $M$ & 13,95 & 1,86 & 7,50 & 2,94 & 137,32 & 474,00 \\
\hline b3 & $p 5$ & A & M & & $P$ a $r$ & $c$ e 1 a & $P e$ & $r d i d$ & a \\
\hline b. 3 & p5 & B & $M$ & & $P a r$ & $c$ e $]$ a & Pe & $r d i d$ & a \\
\hline$b 3$ & p5 & $c$ & M & 13,04 & 0,75 & 17,39 & 2,63 & 124,21 & 495,25 \\
\hline b3 & p5 & 0 & $M$ & 13,42 & 0,80 & 16,77 & 2,73 & 128,66 & 491,00 \\
\hline
\end{tabular}


Tabela 5, Planilha de dados usados para a analise de gantio de peso corrigido para o peso vivo inicial.

\begin{tabular}{|c|c|c|c|c|c|}
\hline Bloco & Periodo & Dieta & Sexo & $\mathrm{P}_{\mathrm{Kg}}$ Inic & $\begin{array}{l}\text { GPD } \\
\mathrm{Kg}\end{array}$ \\
\hline b1 & $\mathrm{p} 1$ & $A$ & $\mathrm{~F}$ & 305 & 0,93 \\
\hline bl & p 1 & $\hat{A}$ & $\mathrm{~F}$ & 320 & 0,86 \\
\hline b1 & pl & $B$ & $\mathrm{~F}$ & 318 & 0,71 \\
\hline bl & p 1 & B & $\mathrm{F}$ & 309 & 0,21 \\
\hline b1 & p 1 & C & $F$ & 296 & 1,00 \\
\hline b 1 & $\mathrm{p} 1$ & $\mathrm{C}$ & $\mathrm{F}$ & 336 & 0,64 \\
\hline b1 & p 1 & $\mathrm{D}$ & $\mathrm{F}$ & 323 & 1,28 \\
\hline b1 & p1 & D & $\mathrm{F}$ & 303 & 1,70 \\
\hline b1 & p2 & $A$ & $\mathrm{~F}$ & 318 & 1,71 \\
\hline b1 & $\mathrm{p} 2$ & $A$ & $\mathrm{~F}$ & 332 & 0,93 \\
\hline b1 & $\mathrm{p} 2$ & B & $\mathrm{F}$ & 328 & 1,36 \\
\hline$b 1$ & p2 & $\mathrm{B}$ & $F$ & 312 & 1,14 \\
\hline b1 & p2 & $\mathrm{C}$ & $\mathrm{F}$ & 310 & 0,64 \\
\hline$b t$ & $p 2$ & C & $F$ & 345 & 1,36 \\
\hline b1 & 02 & $\mathrm{D}$ & $\mathrm{F}$ & 341 & 1,21 \\
\hline bl & $p 2$ & $D$ & $\mathrm{~F}$ & 318 & 1,50 \\
\hline b1 & p3 & A & $\mathrm{F}$ & 342 & 1,07 \\
\hline b1 & p3 & $A$ & $\mathrm{~F}$ & 345 & 1,36 \\
\hline bl & p3 & $B$ & $\mathrm{~F}$ & 328 & 1,28 \\
\hline b1 & p3 & $B$ & $\mathrm{~F}$ & 347 & 1,64 \\
\hline b1 & $p 3$ & $\mathrm{C}$ & $\mathrm{F}$ & 364 & 1,36 \\
\hline bl & n3 & C & $\mathrm{F}$ & 319 & 1,36 \\
\hline bl & p3 & $D$ & $\mathrm{~F}$ & 358 & 1,36 \\
\hline b1 & $p 3$ & D & $\mathrm{F}$ & 339 & 2,00 \\
\hline b1 & p4 & $A$ & $\mathrm{~F}$ & 357 & 0,00 \\
\hline by & $p 4$ & A & $\mathrm{F}$ & 364 & 0,71 \\
\hline b1 & $p 4$ & $B$ & $\mathrm{~F}$ & 370 & 0,78 \\
\hline b1 & $p 4$ & $B$ & $\mathrm{~F}$ & 346 & 0,86 \\
\hline b1 & $p 4$ & $\mathrm{C}$ & $\mathrm{F}$ & 338 & 0,50 \\
\hline bl & p4 & c & $\mathrm{F}$ & 383 & 1,14 \\
\hline b1 & $p 4$ & D & $\mathrm{F}$ & \multirow{2}{*}{\multicolumn{2}{|c|}{$\begin{array}{l}\text { Parcela } \\
\text { Perdida }\end{array}$}} \\
\hline b1 & p4 & 0 & $\mathrm{~F}$ & & \\
\hline b) & p5 & $A$ & $\mathrm{~F}$ & 357 & 2,00 \\
\hline b1 & p5 & $A$ & $\mathrm{~F}$ & 374 & 1,70 \\
\hline by & 05 & $\mathrm{~B}$ & $\mathrm{~F}$ & 381 & 0,90 \\
\hline b1 & p5 & $B$ & $\mathrm{~F}$ & 358 & 0,90 \\
\hline b1 & p5 & C & $\mathrm{F}$ & 345 & 1,10 \\
\hline$b 1$ & p5 & $c$ & $\mathrm{~F}$ & 399 & 1,10 \\
\hline b1 & p 5 & D & $F$ & \multicolumn{2}{|c|}{ Parcela } \\
\hline b1 & 05 & D & $\mathrm{F}$ & \multicolumn{2}{|c|}{ Perdida } \\
\hline b1 & p1 & $A$ & $M$ & 333 & 1,43 \\
\hline b 1 & p1 & $A$ & $M$ & 355 & 1,28 \\
\hline b 1 & p1 & $B$ & $M$ & 347 & 0,21 \\
\hline b1 & $p 1$ & $B$ & $M$ & 345 & 1,00 \\
\hline$b 1$ & 1 & c & $M$ & 332 & 0.64 \\
\hline
\end{tabular}




\begin{tabular}{|c|c|c|c|c|c|}
\hline 81000 & Periodo & Dieta & Sexo & $P_{\overline{K g}}$ Inic & $\begin{array}{l}\text { GPD } \\
\mathrm{Kg}\end{array}$ \\
\hline b 1 & p1 & $C$ & $M$ & 361 & 1,14 \\
\hline b1 & $p 1$ & $D$ & $M$ & 349 & 1,14 \\
\hline b1 & p 1 & 0 & $M$ & 345 & 1,71 \\
\hline b1 & $\mathrm{p} 2$ & $A$ & $M$ & 353 & 1,28 \\
\hline b1 & $p_{2}$ & A & $M$ & 373 & 1,78 \\
\hline b1 & $p 2$ & $B$ & $M$ & 350 & 2,14 \\
\hline bl & $p_{2}$ & $B$ & $M$ & 359 & 1,64 \\
\hline b 1 & p2 & $C$ & $M$ & 341 & 1,36 \\
\hline b1 & $\mathrm{p} 2$ & C & $M$ & 377 & 1,36 \\
\hline b 1 & $p 2$ & $D$ & $M$ & 365 & 1,71 \\
\hline b 1 & $p 2$ & $D$ & $M$ & 369 & 1,78 \\
\hline b1 & p3 & $A$ & $M$ & 371 & 1,07 \\
\hline b 1 & p3 & $A$ & $M$ & 398 & 1,21 \\
\hline b1 & p3 & B & $M$ & 382 & 1,14 \\
\hline b1 & p3 & $B$ & $M$ & 380 & 1,07 \\
\hline b1 & p3 & $c$ & $M$ & 396 & 1,21 \\
\hline b 1 & p3 & C & $M$ & 360 & 0.79 \\
\hline b 1 & p3 & 0 & $M$ & 389 & 1,28 \\
\hline b) 1 & D3 & $\mathrm{D}$ & $M$ & 394 & 2,07 \\
\hline$b_{1}$ & 14 & $A$ & $M$ & 386 & 1,42 \\
\hline b 1 & p4 & $A$ & $M$ & 415 & 1,36 \\
\hline$b 1$ & D4 & $B$ & $M$ & 395 & 0,92 \\
\hline$b 1$ & p4 & $B$ & $M$ & 398 & 2,00 \\
\hline bi & p4 & $\mathrm{C}$ & $M$ & 371 & 1,42 \\
\hline b1 & $p 4$ & $\mathrm{C}$ & $M$ & 413 & 0,78 \\
\hline b 1 & p4 & D & $M$ & 407 & 1,64 \\
\hline b1 & $p 4$ & 0 & $M$ & 423 & 0,86 \\
\hline b 1 & p5 & A & $M$ & 406 & 0,70 \\
\hline b1 & p5 & A & $M$ & 434 & 0,70 \\
\hline 61 & 05 & $B$ & $M$ & 408 & 1,70 \\
\hline b1 & p5 & $\mathrm{B}$ & $M$ & 426 & 1,10 \\
\hline b1 & p 5 & C & $M$ & 391 & 0,90 \\
\hline b1 & p5 & C & $M$ & 424 & 0,90 \\
\hline b1 & p5 & D & $M$ & 430 & 1,50 \\
\hline b 1 & $\mathrm{p} 5$ & $D$ & $M$ & 435 & 1,50 \\
\hline b2 & $p 1$ & $A$ & $M$ & 297 & 1,64 \\
\hline b2 & $\mathrm{p} 1$ & $A$ & $M$ & 317 & 1,50 \\
\hline b2 & p 1 & $B$ & $M$ & 314 & 1,36 \\
\hline b2 & pl & $\mathrm{B}$ & $M$ & 305 & 0,71 \\
\hline b2 & $p 1$ & C & $M$ & 302 & 1,64 \\
\hline$b_{2}$ & $\mathrm{p} 1$ & $C$ & $M$ & 314 & 0,71 \\
\hline b2 & p 1 & $D$ & $M$ & 321 & 0,79 \\
\hline $\mathrm{b} 2$ & p 1 & $\mathrm{D}$ & $M$ & 294 & 0,50 \\
\hline b2 & p2 & $A$ & $M$ & 320 & 1.50 \\
\hline$b 2$ & $\mathrm{p} 2$ & A & $M$ & 338 & 1,71 \\
\hline $\mathrm{b2}$ & 122 & $B$ & $M$ & 333 & 1,21 \\
\hline b2 & $\mathrm{p} 2$ & $B$ & $M$ & 315 & 1,36 \\
\hline$b 2$ & $\mathrm{p} 2$ & $c$ & $M$ & 325 & 1,78 \\
\hline
\end{tabular}




\begin{tabular}{|c|c|c|c|c|c|}
\hline B 1000 & Periodo & Dieta & Sexo & $P_{\text {Kg Inic }}$ & $\begin{array}{l}\mathrm{GPD} \\
\mathrm{Kg}\end{array}$ \\
\hline b2 & p2 & $C$ & $M$ & 324 & 1,78 \\
\hline b2 & $p 2$ & 0 & $M$ & 332 & 1,57 \\
\hline$b_{2}$ & p 2 & D & $M$ & 301 & 1,78 \\
\hline b2 & p3 & $A$ & $M$ & 341 & 1,43 \\
\hline b2 & p3 & $A$ & $M$ & 362 & 1,28 \\
\hline b2 & p3 & $B$ & $M$ & 334 & 1,64 \\
\hline$b_{2} 2$ & p3 & B & $M$ & 350 & 1,78 \\
\hline b2 & p3 & C & $M$ & 349 & 2,14 \\
\hline b2 & p3 & C & $M$ & 350 & 1,21 \\
\hline b2 & p3 & $D$ & $M$ & 354 & 1,36 \\
\hline b2 & p3 & 0 & $M$ & 326 & 1,14 \\
\hline b2 & $p 4$ & $A$ & $M$ & 361 & 1,36 \\
\hline b2 & $p 4$ & $A$ & $M$ & 380 & 0,71 \\
\hline $\mathrm{b} 2$ & $p 4$ & $B$ & $M$ & 375 & 0,86 \\
\hline b2 & $p 4$ & $B$ & $M$ & 357 & 1,78 \\
\hline b2 & $p 4$ & $C$ & $M$ & 367 & 1,00 \\
\hline b2 & p4 & C & $M$ & 379 & 1,36 \\
\hline b2 & p4 & D & $M$ & 373 & 1,64 \\
\hline b2 & $p 4$ & D & $M$ & 342 & 1,42 \\
\hline b2 & p5 & $A$ & $M$ & 380 & 1,70 \\
\hline b2 & p5 & $A$ & $M$ & 390 & 1,00 \\
\hline b2 & p5 & $\mathrm{B}$ & $M$ & 387 & 1,10 \\
\hline b2 & p5 & $B$ & $M$ & 382 & 1,50 \\
\hline b2 & p5 & $C$ & $M$ & 381 & 0,50 \\
\hline b2 & p 5 & C & $M$ & 398 & 0,60 \\
\hline b2 & p 5 & D & $M$ & 396 & 1,10 \\
\hline b2 & p5 & D & $M$ & 362 & 1,20 \\
\hline b2 & p1 & A & $F$ & 282 & 1,14 \\
\hline b2 & p1 & $A$ & $\mathrm{~F}$ & 286 & 0,71 \\
\hline b2 & p 1 & $B$ & $F$ & 291 & 0,79 \\
\hline b2 & pl & $B$ & $F$ & 280 & 0,57 \\
\hline b2 & p1 & $c$ & $F$ & 284 & 1,07 \\
\hline b2 & p 1 & $C$ & $F$ & 286 & 1,14 \\
\hline b2 & pi & D & $F$ & 286 & 0,86 \\
\hline b2 & pi & $D$ & $F$ & 284 & 0,86 \\
\hline b2 & p2 & $A$ & $F$ & 298 & 1,07 \\
\hline b2 & p 2 & A & $\mathrm{F}$ & 296 & 1,14 \\
\hline b2 & $p 2$ & $B$ & $\mathrm{~F}$ & 302 & 1,36 \\
\hline b2 & p2 & $B$ & $F$ & 288 & 1,36 \\
\hline b2 & p2 & $C$ & $F$ & 299 & 1,28 \\
\hline b2 & p2 & $C$ & $F$ & 302 & 1,14 \\
\hline b2 & $\mathrm{p} 2$ & $D$ & $F$ & 298 & 1,28 \\
\hline b2 & p2 & $D$ & $F$ & 296 & 1,14 \\
\hline b2 & p3 & $A$ & $F$ & 313 & 0,64 \\
\hline b2 & p3 & $A$ & $F$ & 312 & 1,07 \\
\hline b2 & p3 & $B$ & $F$ & 307 & 1,14 \\
\hline b2 & p3 & $B$ & $\mathrm{~F}$ & 321 & 0,64 \\
\hline b2 & p3 & $C$ & $F$ & 318 & 1,21 \\
\hline
\end{tabular}




\begin{tabular}{|c|c|c|c|c|c|}
\hline B 1000 & Periodo & Dieta & Sexo & $P_{\overline{K g}}$ Inic & $\begin{array}{l}\mathrm{GPD} \\
\mathrm{Kg}\end{array}$ \\
\hline b2 & p 3 & C & $\mathrm{F}$ & 317 & 0,86 \\
\hline b2 & p3 & D & $\mathrm{F}$ & 316 & 1,00 \\
\hline b2 & p3 & $D$ & $F$ & 312 & 1,07 \\
\hline b2 & p4 & $A$ & $\mathrm{~F}$ & 322 & 0,86 \\
\hline b2 & $p 4$ & $A$ & $\mathrm{~F}$ & 327 & 1,00 \\
\hline b2 & $\mathrm{p} 4$ & $B$ & $\mathrm{~F}$ & 330 & 0,71 \\
\hline b2 & $\mathrm{p} 4$ & B & $F$ & 323 & 0,14 \\
\hline b2 & p4 & C & $\mathrm{F}$ & 329 & 1,14 \\
\hline$b_{2}$ & $p 4$ & C & $\mathrm{F}$ & 335 & 0,92 \\
\hline$b_{2}$ & $p 4$ & $D$ & $\mathrm{~F}$ & 330 & 1,21 \\
\hline b2 & $\mathrm{p} 4$ & $D$ & $F$ & 327 & 1,14 \\
\hline b2 & p5 & $A$ & $\mathrm{~F}$ & 334 & 0,80 \\
\hline b2 & p5 & $A$ & $F$ & 341 & 0,40 \\
\hline b2 & p5 & B & $\mathrm{F}$ & 340 & 1,50 \\
\hline $\mathrm{b} 2$ & p5 & B & $F$ & 325 & 1,30 \\
\hline b2 & p5 & $\mathrm{C}$ & $\mathrm{F}$ & 345 & 0,80 \\
\hline$b 2$ & p5 & C & $\mathrm{F}$ & 348 & 1,00 \\
\hline$b_{2}$ & p5 & D & $\mathrm{F}$ & 347 & 0,80 \\
\hline $\mathrm{b}_{2}$ & 05 & 0 & $\mathrm{~F}$ & 343 & 0,30 \\
\hline b3 & p1 & $A$ & $M$ & 371 & 1,14 \\
\hline$b^{3}$ & pl & A & $M$ & 425 & 1,14 \\
\hline$b 3$ & $\mathrm{pl}$ & B & $M$ & 416 & 1,43 \\
\hline b3 & 01 & B & $M$ & 373 & 0,07 \\
\hline b3 & pl & $\mathrm{C}$ & $M$ & 379 & 0,43 \\
\hline b3 & $p 1$ & $C$ & $M$ & 409 & 2,43 \\
\hline b3 & pi & D & $M$ & 389 & 2,07 \\
\hline b3 & pi & D & $M$ & 388 & 0,57 \\
\hline b3 & p2 & A & $M$ & 387 & 1,14 \\
\hline b3 & $\mathrm{p} 2$ & $A$ & $M$ & 441 & 0,93 \\
\hline b3 & $\mathrm{p} 2$ & $B$ & $M$ & 436 & 1,71 \\
\hline b3 & $p 2$ & $B$ & $M$ & 374 & 1,93 \\
\hline b3 & p2 & $\mathrm{C}$ & $M$ & 385 & 2,00 \\
\hline b3 & $p 2$ & $c$ & $M$ & 443 & 1,50 \\
\hline b3 & p2 & $D$ & $M$ & 418 & 2,14 \\
\hline b3 & $p 2$ & $D$ & $M$ & 396 & 1,93 \\
\hline b3 & p3 & $A$ & $M$ & 403 & 1,36 \\
\hline b3 & p3 & A & $M$ & 454 & 0,86 \\
\hline b3 & p3 & $B$ & $M$ & 401 & 1,50 \\
\hline b3 & p3 & $B$ & $M$ & 460 & 1,07 \\
\hline b3 & p3 & C & $M$ & 464 & 1,71 \\
\hline b3 & p3 & C & $M$ & 413 & 1,57 \\
\hline b3 & p3 & $D$ & $M$ & 448 & 2,00 \\
\hline b3 & p3 & $D$ & $M$ & 423 & 1,64 \\
\hline b3 & $p 4$ & $A$ & $M$ & 422 & 1,21 \\
\hline b3 & p4 & $A$ & $M$ & 466 & 1,36 \\
\hline b3 & $p 4$ & $B$ & $M$ & \multicolumn{2}{|c|}{ Parcela } \\
\hline b3 & p4 & $B$ & $M$ & \multicolumn{2}{|c|}{ Perdida } \\
\hline b3 & p4 & C & $M$ & 435 & 2,07 \\
\hline
\end{tabular}




\begin{tabular}{|c|c|c|c|c|c|}
\hline Bloco & Periodo & Dieta & Sexo & $\mathrm{P}_{\mathrm{Kg}}$ Inic & $\begin{array}{l}\mathrm{GPL} \\
\mathrm{Kg}\end{array}$ \\
\hline b3 & p4 & C & $M$ & 488 & 2,21 \\
\hline b3 & p4 & $D$ & $M$ & 476 & 1,78 \\
\hline b3 & p4 & $D$ & $M$ & 446 & 1,93 \\
\hline b3 & p 5 & $A$ & $M$ & \multicolumn{2}{|c|}{ Parcela } \\
\hline b3 & p 5 & A & $M$ & \multicolumn{2}{|c|}{ Perdida } \\
\hline b3 & p 5 & $\mathrm{~B}$ & $M$ & \multicolumn{2}{|c|}{ Parcela } \\
\hline b3 & p5 & $\mathrm{B}$ & $M$ & \multicolumn{2}{|c|}{ Perdida } \\
\hline b3 & p5 & C & $M$ & 464 & 0,40 \\
\hline b3 & p5 & C & $M$ & 519 & 1,10 \\
\hline b3 & p5 & $D$ & $M$ & 501 & 0,30 \\
\hline b3 & p5 & 0 & $M$ & 473 & 1,30 \\
\hline
\end{tabular}

